\title{
Molecular Umbrella as a Nanocarrier for Antifungals
}

\author{
Andrzej S. Skwarecki ${ }^{1}$, Dorota Martynow ${ }^{1}$, Maria J. Milewska ${ }^{2}$ and Sławomir Milewski $^{1, *}$ \\ 1 Department of Pharmaceutical Technology and Biochemistry and BioTechMed Centre, \\ Gdańsk University of Technology, 80-233 Gdańsk, Poland; andrzej.skwarecki1@pg.edu.pl (A.S.S.); \\ dorota.koperkiewicz@gmail.com (D.M.) \\ 2 Department of Organic Chemistry and BioTechMed Centre, Gdańsk University of Technology, \\ 80-233 Gdańsk, Poland; marmilew@pg.edu.pl \\ * Correspondence: slamilew@pg.edu.pl; Tel.: +48-58-347-2107
}

Citation: Skwarecki, A.S.; Martynow, D.; Milewska, M.J.; Milewski, S. Molecular Umbrella as a Nanocarrier for Antifungals. Molecules 2021, 26, 5475. https://doi.org/10.3390/ molecules26185475

Academic Editor: Robert Musioł

Received: 5 August 2021

Accepted: 6 September 2021

Published: 8 September 2021

Publisher's Note: MDPI stays neutral with regard to jurisdictional claims in published maps and institutional affiliations.

Copyright: (c) 2021 by the authors. Licensee MDPI, Basel, Switzerland. This article is an open access article distributed under the terms and conditions of the Creative Commons Attribution (CC BY) license (https:// creativecommons.org/licenses/by/ $4.0 /)$.

\begin{abstract}
A molecular umbrella composed of two O-sulfated cholic acid residues was applied for the construction of conjugates with cispentacin, containing a "trimethyl lock" (TML) or odithiobenzylcarbamoyl moiety as a cleavable linker. Three out of five conjugates demonstrated antifungal in vitro activity against $C$. albicans and $C$. glabrata but not against $C$. krusei, with $\mathrm{MIC}_{90}$ values in the $0.22-0.99 \mathrm{mM}$ range and were not hemolytic. Antifungal activity of the most active conjugate 24c, containing the TML-pimelate linker, was comparable to that of intact cispentacin. A structural analogue of $\mathbf{2 4 c}$, containing the Nap- $\mathrm{NH}_{2}$ fluorescent probe, was accumulated in Candida cells, and TML-containing conjugates were cleaved in cell-free extract of C. albicans cells. These results suggest that a molecular umbrella can be successfully applied as a nanocarrier for the construction of cleavable antifungal conjugates.
\end{abstract}

Keywords: molecular umbrella; antifungals; conjugates

\section{Introduction}

In the present SARS COVID-19 pandemic period, it is obvious that in the field of infectious diseases, special attention is focused on progress in the prevention of viral infections and antiviral chemotherapy. However, one cannot underestimate the fact that microbial resistance to antibiotics has emerged, and its spread worldwide has resulted in another significant threat to public health [1]. This challenge is also valid in the case of infections caused by human pathogenic fungi. Fungal micro-organisms from the Candida genus, especially Candida albicans and Candida glabrata but also an emerging pathogen Candida auris and filamentous fungi of Aspergillus spp., are etiological factors of many serious, often deadly infectious diseases, especially in immunocompromised patients [2]. C. albicans is considered the fourth most popular etiological agent of nosocomial infections worldwide [3]. There are several mechanisms of drug resistance of human pathogenic fungi, including those concerning alterations of drug transport across the microbial membranes, resulting from an impaired uptake of a drug molecule by membrane-located permeases or from its efflux, driven by multi-drug (MDR) energy-dependent drug transporters [4]. There is a generally accepted opinion on the urgent need for novel antifungal chemotherapeutics, especially these attacking new molecular targets. However, a number of drug candidates, including known inhibitors of intracellular enzymes identified as targets for antifungals, exhibit poor cellular penetration, owing to their hydrophilicity. One of the most promising strategies for overcoming this problem is the use of molecular carriers to ensure the delivery of enzymatic inhibitors to the intracellular target site [5], which is known as the "Trojan horse strategy". This approach is based on idea of conjugation of an active substance with a macromolecular or low molecular weight organic carrier easily penetrating the cell membrane [6]. After internalization, the conjugate remains intact or is cleaved, and the released active component can reach its intracellular target. Among the different organic nanocarriers proposed so far, an unique mechanism of internalization is characteristic for 
compounds known as "molecular umbrellas" [7]. They are "amphomorphic" compounds composed of two or more facial amphiphiles (mostly bile acids) that are connected to a central scaffold (spermine or spermidine). Molecular umbrellas were found capable of transporting certain hydrophilic molecules across liposomal and biological membranes [8] but have not been used so far as nanocarriers in antimicrobial conjugates. Interestingly, the conjugation of a molecular umbrella with known antifungal antibiotic Amphotericin B results in the "taming" of this drug, and as a consequence, improved selective toxicity $[9,10]$.

In this work, rationally designed cleavable conjugates of the diwalled molecular umbrella with cispentacin, an inhibitor of Ile-tRNA ${ }^{\text {Ile }}$ synthetase, have been tested as antifungal agents.

\section{Results}

\subsection{Rationale for Design of Conjugates}

A basic rationale in this work was application of the molecular umbrella scaffold for the construction of conjugates with an inhibitor of intracellular fungal enzyme. The molecular umbrella was supposed to play the role of a nanocarrier responsible for the translocation of a conjugate through the fungal cytoplasmic membrane. Then, an enzymatic inhibitor should have been released from a conjugate intracellularly due to the presence of a cleavable linker, joining the nanocarrier and the cargo.

The simplest diwalled molecular umbrella was chosen as an optimal carrier, since it had been previously shown as the most effective umbrella component of conjugates with an antifungal antibiotic Amphotericin B, where its presence resulted in decreased mammalian toxicity [10]. We expected that the larger, tetra- or octawalled umbrellas may have problems with penetration through the fungal cell wall. Cispentacin, chosen as a cargo component, is an inhibitor of fungal Ile-tRNA ${ }^{\text {Ile }}$ synthetase and as a consequence protein biosynthesis [11], which demonstrates antifungal activity [12]. This compound, for its polar character, does not penetrate biological membranes by simple diffusion but is taken up by the transmembrane transporter, proline permease [13]. For this reason, its activity is lower in L-proline containing complex media, where this amino acid competes with cispentacin for the permease and fungal resistance to this antifungal, and its analogue BAY 10-8888 is most often caused by decreased accumulation [14]. The need for a cleavable linker was obvious, since cispentacin interacts with its target exclusively as an intact molecule. In this work, two types of such linkers were employed. $o$-Dithiobenzylcarbamoyl moiety, previously successfully applied in the synthesis of a molecular umbrella-oligopeptide conjugate [8], contains a disulfide bond, which is potentially cleavable upon an intracellular thiol exchange reaction with the reduced glutathione. Nevertheless, this linker has not been employed so far for the construction of antimicrobial umbrella conjugates. The esterase-triggered TML ('trimethyl lock') [15], applied originally in antibacterial siderophore conjugates [16,17], has been for the first time used for the construction of potential antifungal conjugates.

\subsection{Chemistry}

Nine cleavable conjugates of a diwalled molecular umbrella with an antifungal agent, cispentacin, or with a fluorescent probe, Lys(Mca) (4-carboxymethyl-7-methoxycoumarin) or Nap- $\mathrm{NH}_{2}$ ( $\mathrm{N}$-butyl-4-aminoethyl-1,8-naphtalimide), as cargo components were synthesized (Figure 1). Seven out of nine conjugates contained the esterase-sensitive TML system, and the remaining two contained the $o$-dithiobenzylcarbamoyl linker. 

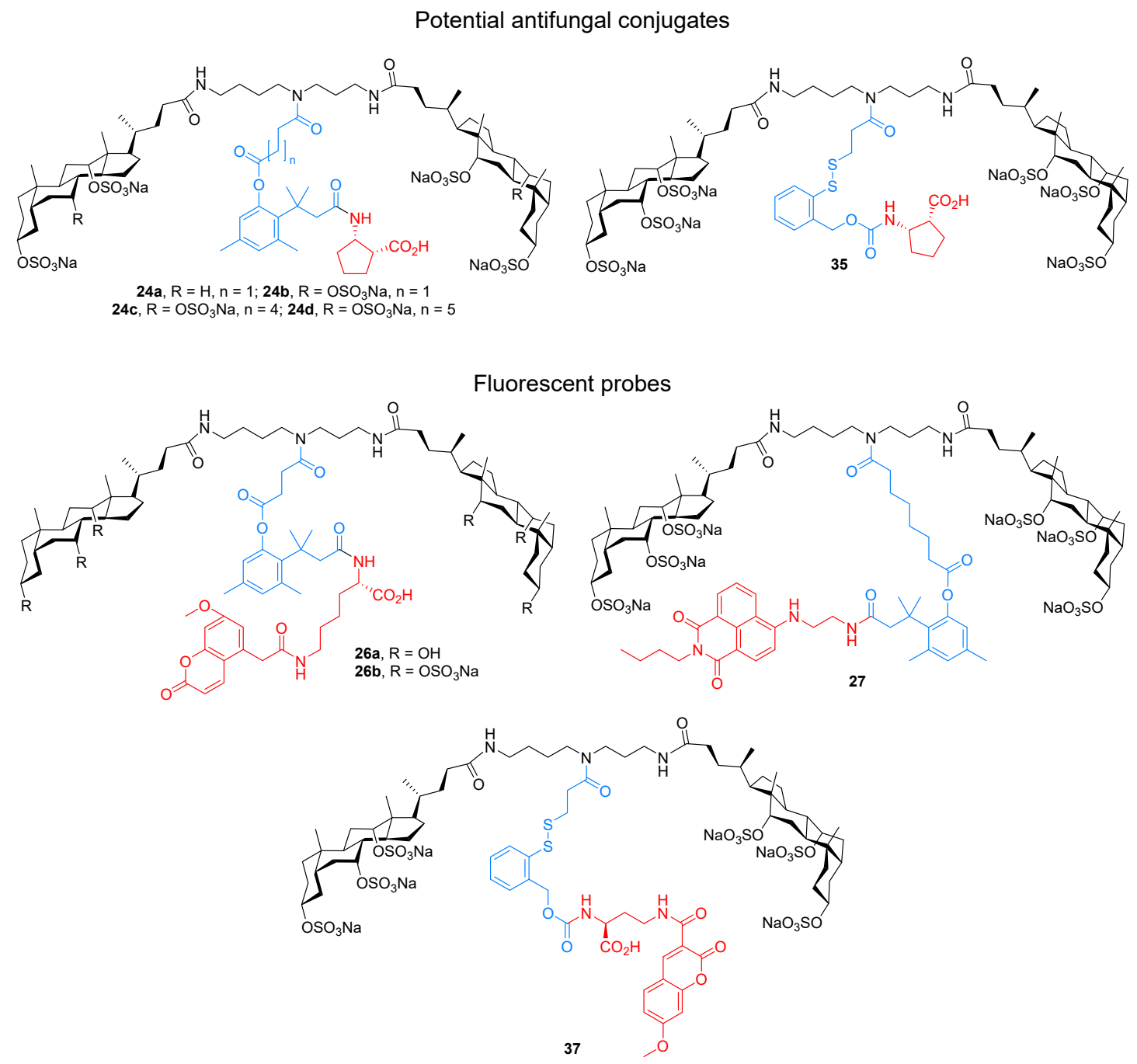

Figure 1. Structures of molecular umbrella conjugates studied in this work. The linker fragment is shown in blue and a cargo fragment (cispentacin in $\mathbf{2 4 a - d}$, Lys(Mca) in 26a,b and 37 and $\mathrm{Nap}-\mathrm{NH}_{2}$ in 27) is shown in red.

The synthesis of the esterase-labile TML linker started from pimelic $\mathbf{2 a}$ and suberic $\mathbf{2 b}$ acids, which were converted into corresponding cyclic anhydrides, using acetic anhydride. The resulting anhydrides $\mathbf{1 b}, \mathbf{c}$ and commercially available succinic anhydride $\mathbf{1 a}$ were subsequently lysed with tert-butanol to dicarboxylic acid monoesters $\mathbf{3 a}-\mathbf{c}$ in the manner described by Cisneros et al. [18].

The $O$-acylated TML systems 14a-c were prepared in a multistep synthesis presented in Scheme 1, being a modified version of the procedure described by Ji and Miller [16]. Condensation of the commercially available methyl 3-methylbut-2-enoate 4 with 3,5dimethylphenol 5 gave lactone 6 , which after reduction with $\mathrm{LiAlH}_{4}$ resulted in the primary alcohol 7. Subsequently, the phenolic hydroxyl group of 7 was selectively protected with TBDMSCl (tert-butyldimethylchlorosilane). The protected alcohol 8 was acylated with appropriate carboxylic acid $\mathbf{3 a}-\mathbf{c}$ by Steglich esterification. The primary hydroxyl groups of esters $\mathbf{9 a - c}$ were deprotected under mildly acidic conditions, resulting in alcohols 10a-c, which underwent subsequent oxidation to corresponding aldehydes 11a-c and then to carboxylic acids 12a-c. The formed carboxylic group was protected with benzyl bromide, thus forming triesters $13 \mathbf{a}-\mathbf{c}$. The subsequent deprotection of tert-butyl esters with trifluoroacetic acid gave carboxylic acids 14a-c (Scheme 1). 


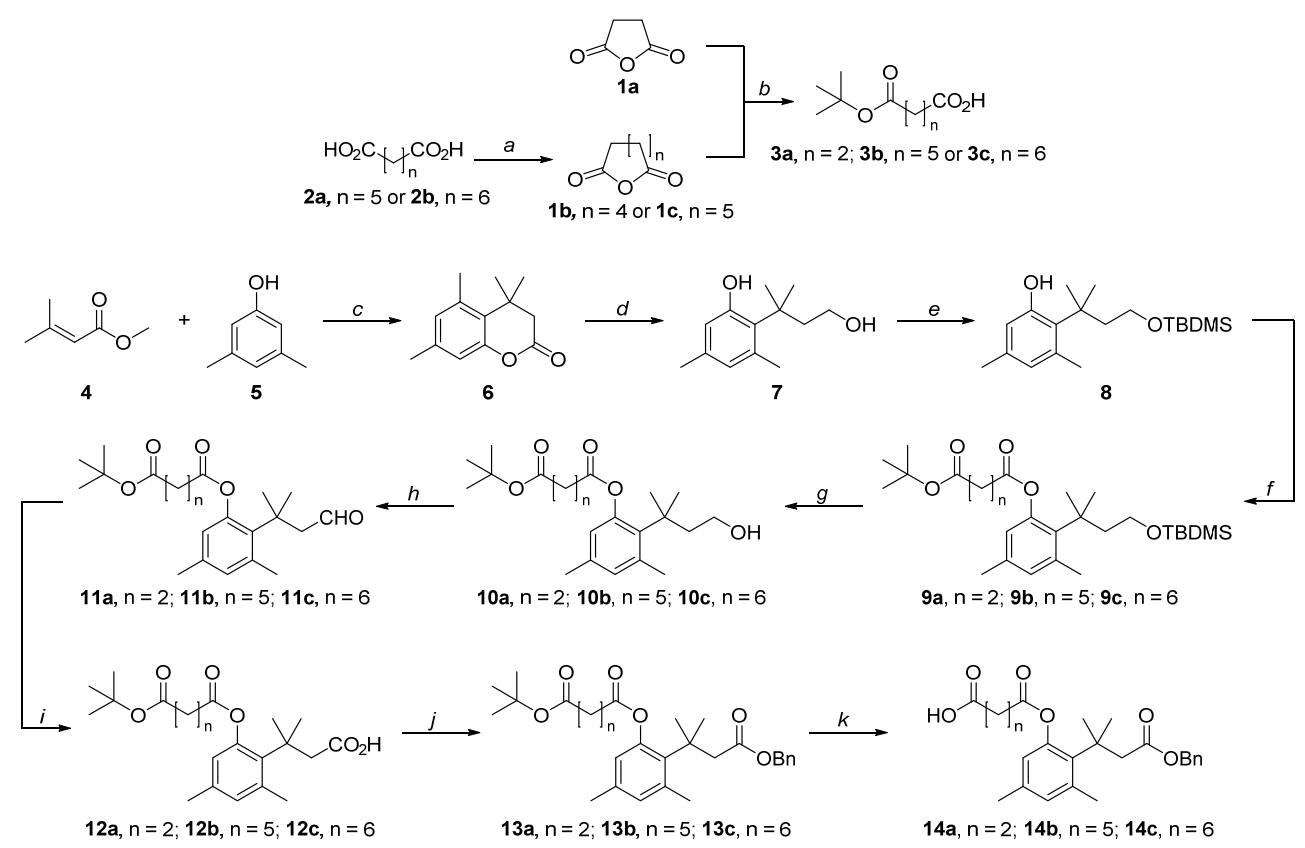

Scheme 1. Synthesis of the 'trimethyl lock' building block. Reaction conditions: a. $\mathrm{Ac}_{2} \mathrm{O}$, reflux, 4 h; b. NHS (0.3 equiv.), DMAP (0.2 equiv.), TEA (0.3 equiv.), $t \mathrm{BuOH}$ (2 equiv.), $\mathrm{PhCH}_{3}$, reflux, 24 h; c. $\mathrm{MeSO}_{3} \mathrm{H}, 70{ }^{\circ} \mathrm{C}, 18 \mathrm{~h}$; d. $\mathrm{LiAlH}_{4}$ (4 equiv.), THF, rt, 3 h; e. TBDMSCl (1.2 equiv.), DMAP (1.7 equiv.), DCM, Ar, $2 \mathrm{~h}$ at $0{ }^{\circ} \mathrm{C}$ then $3 \mathrm{~h}$ at rt; f. 3a-c (1.5 equiv.), DCC (2 equiv.), DMAP (0.1 equiv.), DCM, $1 \mathrm{~h}$ at $0{ }^{\circ} \mathrm{C}$ then $48 \mathrm{~h}$ at rt; g. THF $/ \mathrm{H}_{2} \mathrm{O} / \mathrm{AcOH}(1 / 1 / 3, v / v / v), \mathrm{rt}, 3 \mathrm{~h} ; \mathrm{h}$. PCC (2 equiv.), DCM, Ar, rt, $4 \mathrm{~h}$; i. $\mathrm{NaClO}_{2}$ (1.5 equiv.), $\mathrm{NaH}_{2} \mathrm{PO}_{4}$ (0.3 equiv.), $\mathrm{H}_{2} \mathrm{O}_{2}$ (1.4 equiv.), $\mathrm{MeCN} / \mathrm{H}_{2} \mathrm{O}(3 / 1, v / v), 0{ }^{\circ} \mathrm{C}, 1 \mathrm{~h}$; j. $\mathrm{BnBr}\left(1.5\right.$ equiv), $\mathrm{KHCO}_{3}$ (2 equiv.), DMF, $40{ }^{\circ} \mathrm{C}, 3 \mathrm{~h}$; $\mathrm{k}$. DCM/TFA $(3 / 1 \mathrm{v} / \mathrm{v}), \mathrm{rt}, 1 \mathrm{~h}$.

Formation of the molecular umbrella structure on the prepared TML linker started with the conjugation of carboxylic acids 14a-c with Boc-protected spermidine 16, as presented in Scheme 2. The synthesis of protected spermidine was accomplished in a one-step reaction of spermidine 15 with 2 equivalents of protecting agent, Boc-ON. The resulting amine 16 was subsequently acylated with NHS (N-hydroxysuccinimide)-activated TML linkers 17a-c (NHS/DCC method), and then, the benzyl protecting group was removed by hydrogenolysis on $\mathrm{Pd} / \mathrm{C}$ catalyst. The resulting carboxylic acids 19a-c were universal building blocks for further conjugation with cargo molecules.
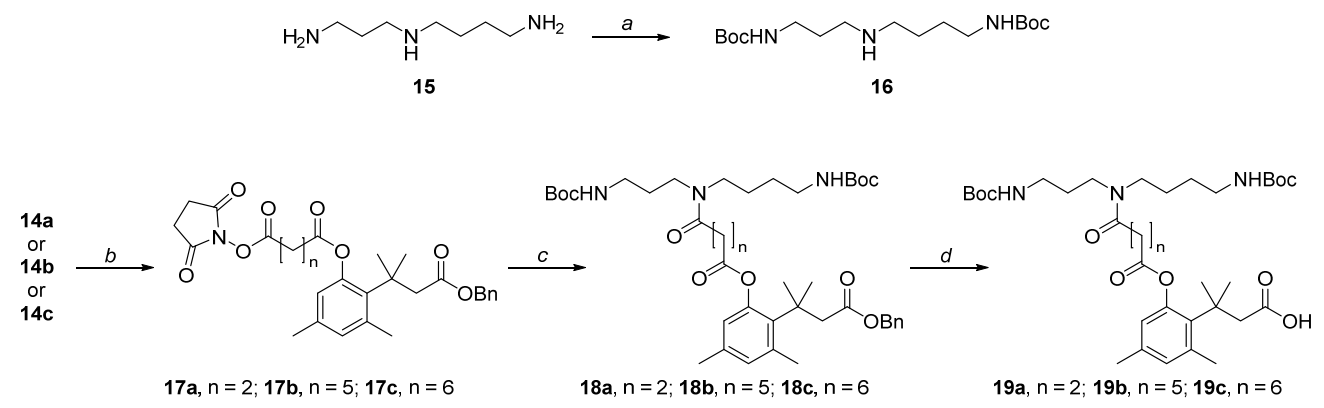

Scheme 2. Synthesis of Boc-protected spermidine and its conjugation with the 'trimethyl lock' building block. Reaction conditions: a. Boc-ON (2 equiv.), THF, $0{ }^{\circ} \mathrm{C}, 4 \mathrm{~h}$; b. NHS (1.3 equiv.), DCC (1.8 equiv.), DCM, rt, 24 h; c. 16 (1.3 equiv.), DIPEA (3 equiv.), DCM, rt, 5 h; d. H2 (balloon), $10 \% \mathrm{Pd} / \mathrm{C}$ (cat.), THF, rt, $4 \mathrm{~h}$.

The antifungal agent, cispentacin, was connected to the 'trimethyl lock' linker by amide bond formation, which was accomplished by the activation of carboxylic acids 19a-c with TDBTU (O-(3,4-dihydro-4-oxo-1,2,3-benzotriazin-3-yl)- $N, N, N^{\prime}, N^{\prime}$-tetramethyluronium tetrafluoroborate) followed by aminolysis with cispentacin (Scheme 3). The resulting 
amides 23a-c were deprotected under acidic conditions of trifluoroacetic acid and used for the ultimate formation of the molecular umbrella. For that purpose, deoxycholic acid $\mathbf{2 0 a}$ and cholic acid $\mathbf{2 2 b}$ were converted into appropriate active esters $\mathbf{2 2 a} \mathbf{a} \mathbf{c}$. The formation of ester 22c was straightforward and was accomplished using the NHS/DCC technique. For the preparation of active esters 22a,b, cholic and deoxycholic acids were previously converted into sulfate derivatives $\mathbf{2 1 a}, \mathbf{b}$ by esterification with a sulfur trioxide/pyridine complex. Then, salts 21a, $\mathbf{b}$ were converted to active esters 22a, $\mathbf{b}$ with TDBTU (Scheme 3 ). Active esters $\mathbf{2 2} \mathbf{a}, \mathbf{b}$ were used for the acylation of spermidine terminal amino groups, which resulted in final molecular umbrella-cispentacin conjugates $\mathbf{2 4 a - d}$, differing by the length of the "trimethyl lock" containing linkers and the presence or absence of sulfate groups in the cholic acid "walls".
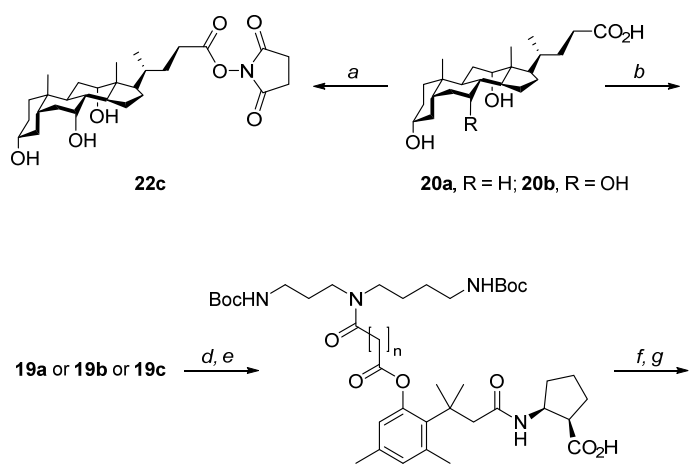

23a, $n=2 ; 23 b, n=5 ; 23 c, n=6$
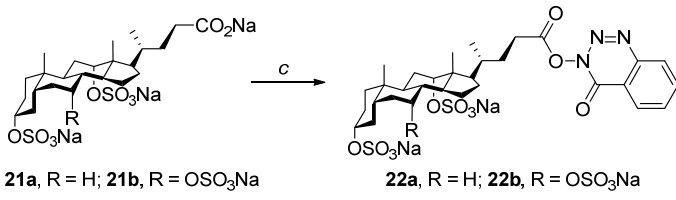

22a, $\mathrm{R}=\mathrm{H} ; \mathbf{2 2 b}, \mathrm{R}=\mathrm{OSO}_{3} \mathrm{Na}$

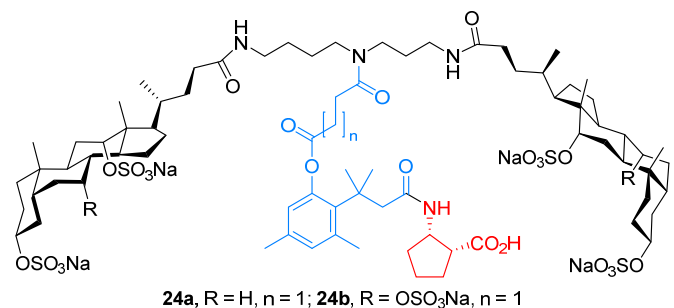

$24 a, R=H, n=1 ; 24 b, R=O S O_{3} \mathrm{Na}, \mathrm{n}=1$
$\mathbf{2 4 c}, \mathrm{R}=\mathrm{OSO}_{3} \mathrm{Na}, \mathrm{n}=4 ; 24 \mathrm{~d}, \mathrm{R}=\mathrm{OSO}_{3} \mathrm{Na}, \mathrm{n}=5$

Scheme 3. Synthesis of molecular umbrella-cispentacin conjugates carrying the 'trimethyl lock' linker. Reaction conditions: a. NHS (1 equiv.), DCC (1.2 equiv.), THF, rt, 24 h; b. SO 3 /Py complex (18 equiv.), DMF, rt, 24h; c. TDBTU (1.2 equiv.), DIPEA ( 1 equiv.), DMF, rt, 2 h; d. TDBTU (1.5 equiv.), DIPEA (3 equiv.), DMF, rt, $2 \mathrm{~h}$; e. cispentacin (1.5 equiv.), DIPEA (16 equiv.), DMF, rt, 2 h; f. DCM/TFA (3/1, v/v), rt, 1 h; g. 22a or 22b (2 equiv.), DIPEA (22 equiv.), DMF, rt, $24 \mathrm{~h}$.

Conjugates carrying fluorescent probes, Lys(Mca) or Nap- $\mathrm{NH}_{2}$, as cargo were prepared analogously as conjugates $\mathbf{2 4 b -} \mathbf{d}$. In the case of conjugate $\mathbf{2 6 a}$, an active ester $\mathbf{2 2 c}$ was used as an acylating agent (Scheme 4 ).
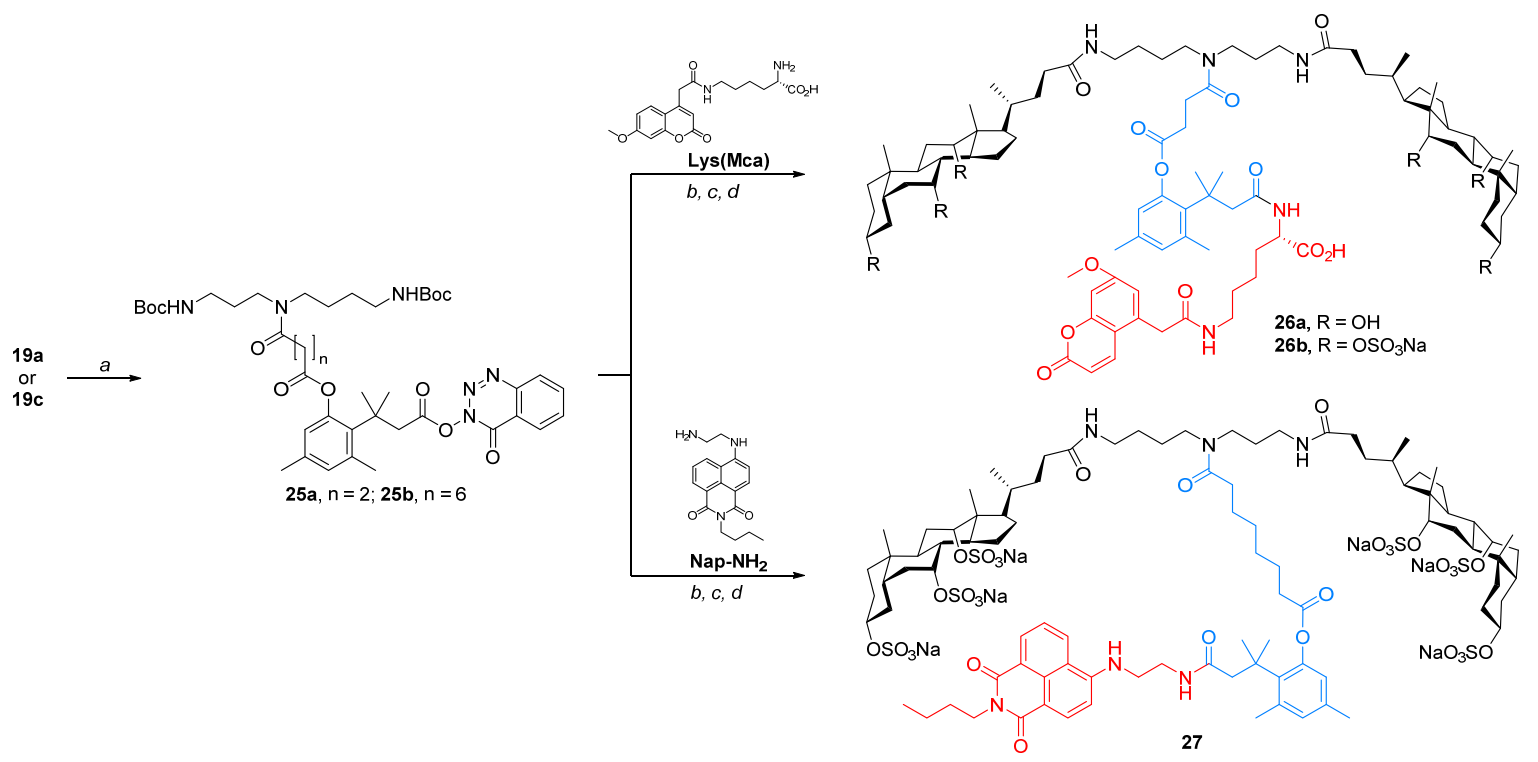

Scheme 4. Synthesis of molecular umbrella-fluorescent agent conjugates carrying the 'trimethyl lock' linker. Reaction conditions: a. TDBTU (1.5 equiv.), DIPEA (3 equiv.), DMF, rt, 2 h; b. Lys(Mca) or Nap- $\mathrm{NH}_{2}$ (1.5 equiv.), DIPEA (16 equiv.), DMF, rt, 2 h; c. DCM/TFA (3/1,v/v), rt, 1 h; d. 22b or 22c (1.5 equiv.), DIPEA (16 equiv.), DMF, rt, 2 h. 
The synthesis of molecular umbrella conjugates with a o-dithiobenzoylcarbamoyl linker was inspired by the research work of Jing et al. [19]. As shown in Scheme 5, the synthesis began with commercially available active diester 28 , which was converted to a dimeric structure 29 by amide formation with 2 equivalents of $\mathrm{Boc}_{2}$-protected spermidine $\mathbf{1 6}$. Intermediate 29 was subsequently cleaved to corresponding thiol 30, using TCEP (tris(2carboxyethyl)phosphine) as a reducing agent. Then, a thiol group was activated with asymmetric disulfide $\mathbf{3 1}$, affording a mixed disulfide $\mathbf{3 2}$, which underwent an activation reaction with DSC ( $N, N^{\prime}$-disuccinimidyl carbonate). Active ester 33 reacted with cispentacin, which resulted in urethane bond formation in derivative 34. As in the case of TML-containing conjugates, the Boc-protecting groups were removed with TFA, and the resulting primary amino groups were acylated with cholic acid active ester $\mathbf{2 2} \mathbf{b}$, leading to the final conjugate 35 .

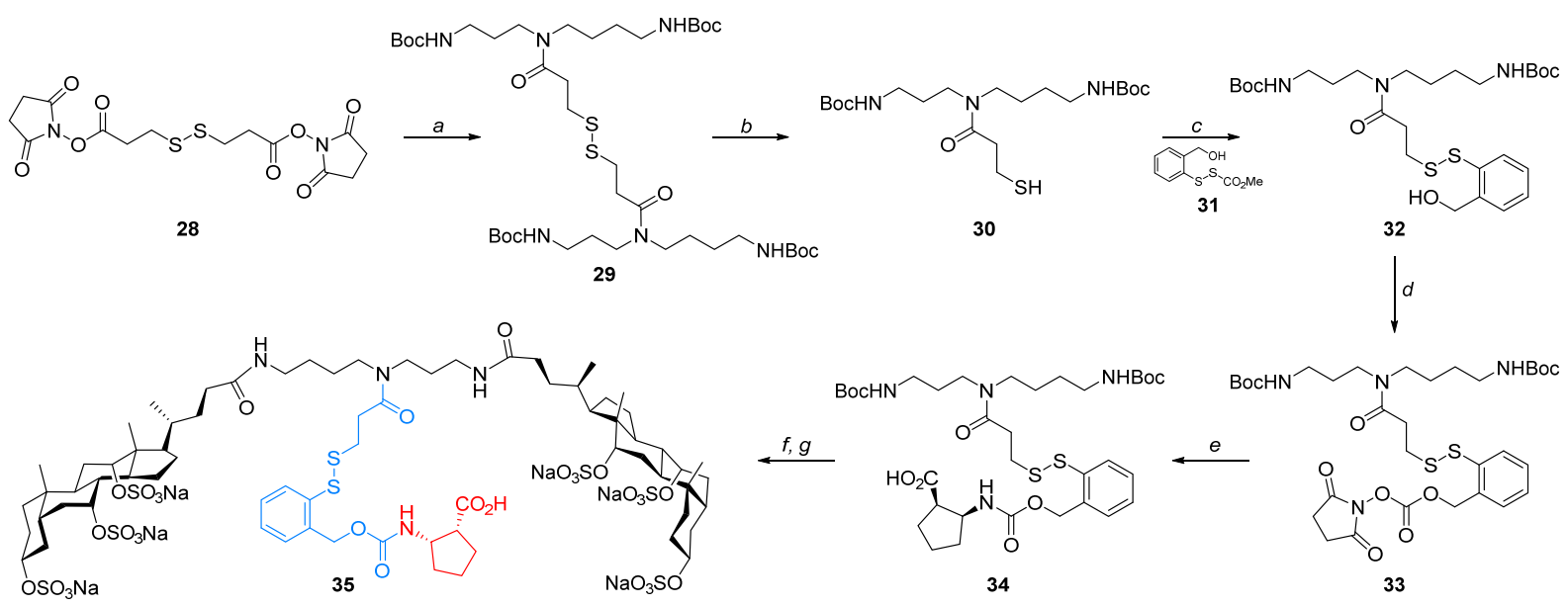

Scheme 5. Synthesis of molecular umbrella-cispentacin conjugate carrying the $o$-dithiobenzylcarbamoyl linker. Reaction conditions: a. 16 (2 equiv.), DIPEA (2 equiv.), THF, rt, 24 h; b. TCEP (1.5 equiv.), $\mathrm{MeOH} / \mathrm{H}_{2} \mathrm{O}, \mathrm{rt}, 1$ h; c. 31 (1.2 equiv.), TEA (2 equiv.), MeOH, rt, 2 h; d. DSC (1 eqiuv.), TEA (1 equiv.), MeCN, rt, 2 h; e. cispentacin (1.5 equiv.), TEA (2 equiv.), $\mathrm{H}_{2} \mathrm{O} / \mathrm{MeCN}(1 / 1, v / v)$, rt, 2 h; f. DCM/TFA (3/1, v/v), rt, 1 h; g. 22 b (2 equiv.), DIPEA (4 equiv.), DMF, rt, 5 h.

Conjugate 37, carrying the Lys(Mca) fluorescent probe as a cargo, was prepared analogously as conjugate 35 (Scheme 6).
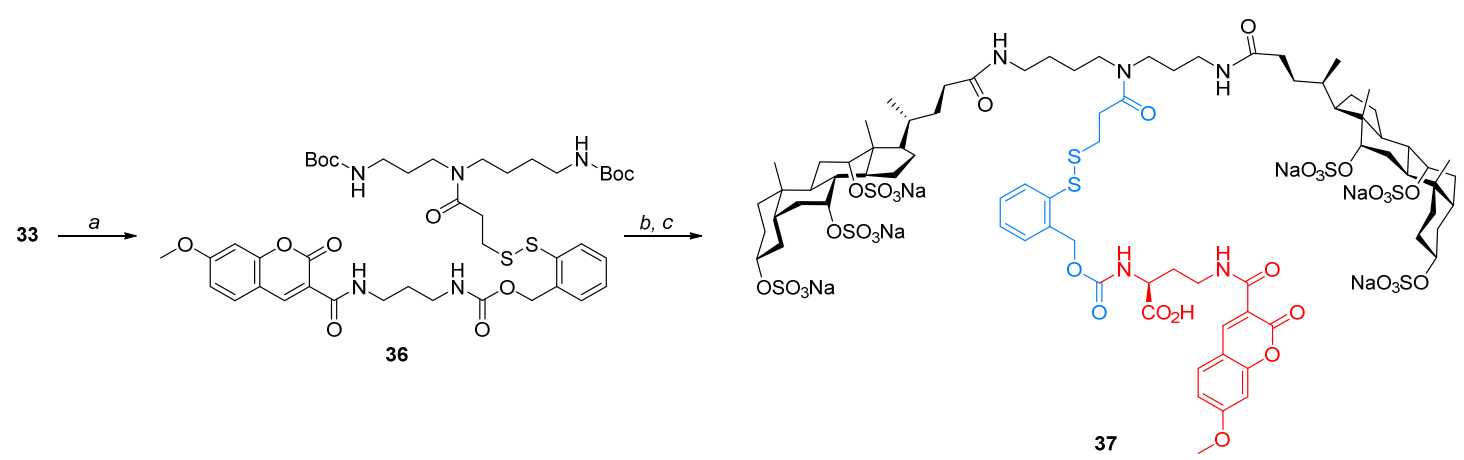

Scheme 6. Synthesis of molecular umbrella-fluorescent agent conjugate carrying $o$-dithiobenzoylcarbamoyl linker. Reaction conditions: a. Lys(Mca) (1.5 equiv.), TEA (2 equiv.), $\mathrm{H}_{2} \mathrm{O} / \mathrm{MeCN}(1 / 1, v / v), \mathrm{rt}, 2$ h; b. DCM/TFA (3/1, v/v), rt, 1 h; c. 22 b (2 equiv.), DIPEA (4 equiv.), DMF, rt, $5 \mathrm{~h}$.

\subsection{Three Out of Five Umbrella: Cispentacin Conjugates Demonstrate Antifungal In Vitro Activity}

The antifungal in vitro activity of conjugates $24 \mathbf{a}-\mathbf{d}$ and 35 was determined by the serial two-fold dilution method, using the 96-well microtiter plates, in two growth media, RPMI-1640 and YNB-AS, against seven yeast species from the Candida genus. The $\mathrm{MIC}_{50}$ 
and $\mathrm{MIC}_{90}$ values, i.e., concentrations at which cell growth was inhibited in $50 \%$ and $90 \%$, respectively, were measured and compared to those of the intact cispentacin. The concentration values presented in Tables 1 and 2 are expressed in $\mathrm{mM}$ units to allow the comparison of the compounds' effectiveness at the molecular level. For data expressed in $\mu \mathrm{g} \mathrm{mL} \mathrm{L}^{-1}$ units, such comparison is not possible, since the molecular masses of conjugates $(\approx 1755-2114$ D range) are 14-16-fold higher than that of cispentacin (128.3 D).

Table 1. Antifungal in vitro activity of cispentacin and its conjugates $24 a-d$ and $35 . M_{50}$ and $\mathrm{MIC}_{90}$ values (mM) were determined by the serial two-fold dilution method, using the 96-well microtiter plates, in RPMI-1640 medium. CisP-cispentacin. Data $>1 \mathrm{mM}$ means than no growth inhibition was observed at $1 \mathrm{mM}$.

\begin{tabular}{|c|c|c|c|c|c|c|c|c|c|c|c|c|c|c|}
\hline & \multicolumn{10}{|c|}{ C. albicans } & \multirow{2}{*}{\multicolumn{2}{|c|}{ C. glabrata }} & \multirow{2}{*}{\multicolumn{2}{|c|}{ C. krusei }} \\
\hline & \multicolumn{2}{|c|}{ ATCC 10231} & \multicolumn{2}{|c|}{ B3 } & \multicolumn{2}{|c|}{ B4 } & \multicolumn{2}{|c|}{ Gu4 } & \multicolumn{2}{|c|}{ Gu5 } & & & & \\
\hline & $\mathrm{MIC}_{90}$ & $\mathrm{MIC}_{50}$ & $\mathrm{MIC}_{90}$ & $\mathrm{MIC}_{50}$ & $\mathrm{MIC}_{90}$ & $\mathrm{MIC}_{50}$ & $\mathrm{MIC}_{90}$ & $\mathrm{MIC}_{50}$ & $\mathrm{MIC}_{90}$ & $\mathrm{MIC}_{50}$ & $\mathrm{MIC}_{90}$ & $\mathrm{MIC}_{50}$ & $\mathrm{MIC}_{90}$ & $\mathrm{MIC}_{50}$ \\
\hline $24 a$ & $>>1$ & $>>1$ & $>>1$ & $>>1$ & $>>1$ & $>>1$ & $>>1$ & $>>1$ & $>>1$ & $>>1$ & $>>1$ & $>>1$ & $>>1$ & $>>1$ \\
\hline $24 b$ & $>>1$ & $>>1$ & $>>1$ & $>>1$ & $>>1$ & $>>1$ & $>>1$ & $>>1$ & $>>1$ & $>>1$ & $>>1$ & $>>1$ & $>>1$ & $>>1$ \\
\hline $24 \mathrm{c}$ & 0.24 & 0.17 & 0.27 & 0.20 & 0.28 & 0.19 & 0.23 & 0.16 & 0.25 & 0.18 & 0.90 & 0.40 & $>>1$ & $>>1$ \\
\hline $24 d$ & $>>1$ & $>>1$ & $>>1$ & $>>1$ & $>>1$ & $>>1$ & $>>1$ & $>>1$ & $>>1$ & $>>1$ & $>>1$ & $>>1$ & $>>1$ & $>>1$ \\
\hline 35 & $>>1$ & $>>1$ & $>>1$ & $>>1$ & $>>1$ & $>>1$ & $>>1$ & $>>1$ & $>>1$ & $>>1$ & $>>1$ & $>>1$ & $>>1$ & $>>1$ \\
\hline CisP & 0.34 & 0.08 & 0.36 & 0.21 & 0.58 & 0.34 & 0.42 & 0.26 & 0.64 & 0.41 & $>>1$ & 0.51 & 0.57 & 0.28 \\
\hline
\end{tabular}

Data presented in Table 1 indicate that conjugate 24c demonstrated a growth inhibitory effect in RPMI-1640 medium against all Candida spp. Tested, except for C. krusei. The MIC 50 and $\mathrm{MIC}_{90}$ values of this compound were comparable to those of cispentacin, although $\mathrm{C}$. glabrata was slightly more susceptible to $24 \mathrm{c}$ than to cispentacin, and the same was found for some C. albicans clinical isolates. Compounds 24a, 24b, 24d, and 35 were devoid of antifungal activity in this medium.

Table 2. Antifungal in vitro activity of cispentacin and its conjugates $\mathbf{2 4 a - d}$ and $35 . \mathrm{MIC}_{50}$ and MIC 90 values (mM) were determined by the serial two-fold dilution method, using the 96-well microtiter plates, in YNB-AS medium. CisPcispentacin. Data $>1 \mathrm{mM}$ means than no growth inhibition was observed at $1 \mathrm{mM}$, while $>1 \mathrm{mM}$ indicates that at $1 \mathrm{mM}$, some growth inhibition (10-15\%) was observed.

\begin{tabular}{|c|c|c|c|c|c|c|c|c|c|c|c|c|c|c|}
\hline & \multicolumn{10}{|c|}{ C. albicans } & \multirow{2}{*}{\multicolumn{2}{|c|}{ C. glabrata }} & \multirow{2}{*}{\multicolumn{2}{|c|}{ C. krusei }} \\
\hline & \multicolumn{2}{|c|}{ ATCC 10231} & \multicolumn{2}{|c|}{ B3 } & \multicolumn{2}{|c|}{ B4 } & \multicolumn{2}{|c|}{ Gu4 } & \multicolumn{2}{|c|}{ Gu5 } & & & & \\
\hline & $\mathrm{MIC}_{90}$ & $\mathrm{MIC}_{50}$ & $\mathrm{MIC}_{90}$ & $\mathrm{MIC}_{50}$ & $\mathrm{MIC}_{90}$ & $\mathrm{MIC}_{50}$ & $\mathrm{MIC}_{90}$ & $\mathrm{MIC}_{50}$ & $\mathrm{MIC}_{90}$ & $\mathrm{MIC}_{50}$ & $\mathrm{MIC}_{90}$ & $\mathrm{MIC}_{50}$ & $\mathrm{MIC}_{90}$ & $\mathrm{MIC}_{50}$ \\
\hline $24 a$ & 0.89 & 0.35 & $>1$ & 0.50 & 0.98 & 0.48 & $>>1$ & 0.77 & 0.93 & 0.68 & $>>1$ & $>>1$ & $>>1$ & $>>1$ \\
\hline $24 b$ & 0.87 & 0.30 & 0.95 & 0.30 & 0.88 & 0.34 & 0.99 & 0.44 & $>>1$ & 0.87 & $>1$ & 0.99 & $>>1$ & $>>1$ \\
\hline $24 c$ & 0.22 & 0.13 & 0.29 & 0.17 & 0.23 & 0.12 & 0.25 & 0.14 & 0.22 & 0.11 & 0.99 & 0.55 & $>>1$ & $>>1$ \\
\hline $24 d$ & $>>1$ & $>1$ & $>>1$ & $>1$ & $>>1$ & $>1$ & $>>1$ & $>1$ & $>>1$ & $>1$ & $>>1$ & $>1$ & $>>1$ & $>>1$ \\
\hline 35 & $>>1$ & $>>1$ & $>>1$ & $>>1$ & $>>1$ & $>>1$ & $>>1$ & $>>1$ & $>>1$ & $>>1$ & $>>1$ & $>>1$ & $>>1$ & $>>1$ \\
\hline CisP & 0.10 & 0.02 & 0.15 & 0.11 & 0.28 & 0.17 & 0.18 & 0.15 & 0.39 & 0.27 & 0.50 & 0.10 & 0.15 & 0.09 \\
\hline
\end{tabular}

As shown in Table 2, in minimal YNB-AS medium, a growth inhibitory effect was found for $24 \mathrm{c}$ against $C$. albicans and C. glabrata, but some activity was also observed for $\mathbf{2 4 a}$ and $\mathbf{2 4 b}$ against $C$. albicans.

The $\mathrm{MIC}_{50}$ and $\mathrm{MIC}_{90}$ values of cispentacin in minimal YNB-AS medium were two to three times lower than those in RPMI-1640. The latter medium contains a mixture of proteinogenic amino acids, including L-proline. This amino acid competes with cispentacin for proline permease, thus lowering the growth inhibitory activity of this antifungal. In the case of $24 \mathrm{c}$ conjugate, the difference between its $\mathrm{MIC}_{50}$ and $\mathrm{MIC}_{90}$ values measured in YNB-AS and in RPMI-1640 was much smaller, if any. On the other hand, the 24a and 24b conjugates were inactive in RPMI-1640 but demonstrated some activity in YNB-AS. 
It is not clear which components of the RPMI-1640, not present in YNB-AS, affected the antifungal activity of these two conjugates.

A comparison of the growth inhibitory activities of cispentacin and its conjugates with the diwalled molecular umbrella against clinical FLC (fluconazole)-resistant and FLC-susceptible $C$. albicans strains revealed no substantial difference for $24 \mathrm{c}$ and slightly lower activity of cispentacin against FLC-resistant B4 and Gu5 than against their respective FLC-susceptible counterparts B3 and Gu4. This result suggests than cispentacin could be a substrate for drug efflux pumps, Cdr1p/Cdr2p overexpressed in Gu5 and for Mdr1p present in B4, whereas the conjugates, especially $\mathbf{2 4 c}$, are not.

No antifungal activity in both growth media was found for conjugates of molecular umbrella with fluorescent probes, 26a,b, 27, and 37 .

\subsection{Molecular Umbrella: Cispentacin Conjugates Are Not Hemolytic}

Cispentacin, all five molecular umbrella/cispentacin conjugates $\mathbf{2 4 a - d}$ and $\mathbf{3 5}$, as well as four conjugates with fluorescent probes $\mathbf{2 6 a}, \mathbf{b}, \mathbf{2 7}$, and $\mathbf{3 7}$ were tested for hemolytic activity against human erythrocytes. Conjugates $\mathbf{2 4 a - d}, \mathbf{2 6 a}, \mathbf{b}, \mathbf{2 7}, \mathbf{3 5}$, and 37 were tested in the $2000-16 \mu \mathrm{g} \mathrm{mL}^{-1}$ range (2000 $\mu \mathrm{g} \mathrm{mL}^{-1}$ corresponds to approximately $1 \mathrm{mM}$ concentration) and cispentacin in the 200-1.6 $\mu \mathrm{g} \mathrm{mL}^{-1}$ range. Not more than $7.5 \%$ hemolysis at the higher concentration of each compound was found, which means that all conjugates tested are not hemolytic.

\subsection{Molecular Umbrella: TML:Nap- $\mathrm{NH}_{2}$ Conjugate $\mathbf{2 7}$ Is Accumulated in C. albicans and C. glabrata but Not in C. krusei Cells}

Four conjugates of a molecular umbrella with fluorescent probes, structural analogs of compounds $\mathbf{2 4 a - c}$ and 35 , were constructed in order to use them for studies on the internalization of molecular umbrella conjugates in Candida cells. Three of them, namely 26a, 26b, and 37, contained Mca linked through L-lysine or 2,4-diaminobutanoic acid to the TML system and in 27 , the fluorescent probe was Nap- $\mathrm{NH}_{2}$, which was connected directly to TML.

For uptake studies, Candida cells were treated with a molecular umbrella/fluorescent probe conjugate, and intracellular probe accumulation was monitored by fluorescence microscopy, with $\lambda_{\text {exc }}=438 \mathrm{~nm}$ for Nap- $\mathrm{NH}_{2}$ and $\lambda_{\text {exc }}=350 \mathrm{~nm}$ for Lys(Mca).

The results of microscopic examination of 27 uptake by Candida cells are shown in Figure 2. This conjugate was effectively accumulated in a time-dependent fashion in $C$. albicans and C. glabrata cells but not in C. krusei. No fluorescent probe accumulation was observed with conjugates 26a, 26b, and 37 (images not shown).

\subsection{Conjugates Containing TML Are Cleaved in the Model System and in Cell-Free Extract}

Conjugates 24a-d, containing the TML system, were tested for susceptibility to enzymatic cleavage in the model system with pig liver esterase and in cell-free extract prepared from $C$. albicans cells. Conjugate 35 containing the $o$-dithiobenzylcarbamoyl linker was tested in the model system with glutathione and in C. albicans cell-free extract.

Samples collected from incubation mixtures at time intervals were subjected to HPLCMS analysis. Results of these analyses of mixtures containing products of digestion of conjugates $\mathbf{2 4 c}$ and $24 \mathrm{~d}$ with pig esterase are shown in Figure $3 \mathrm{~A}, \mathrm{~B}$. In both cases, a peak with time-dependent increasing intensity appeared at a location corresponding to that of the intact cispentacin. Presence of the released cispentacin was confirmed by MS spectrum, where a signal at $m / z=128.3$ is clearly shown. The respective peak was not present in chromatograms of mixtures resulting from pig esterase treatment of $\mathbf{2 6 a}$ and $\mathbf{2 6 \mathbf { b }}$ but was found in the chromatogram of post-reaction mixture resulting from glutathione action on 35 (not shown). 
C. albicans ATCC 10231
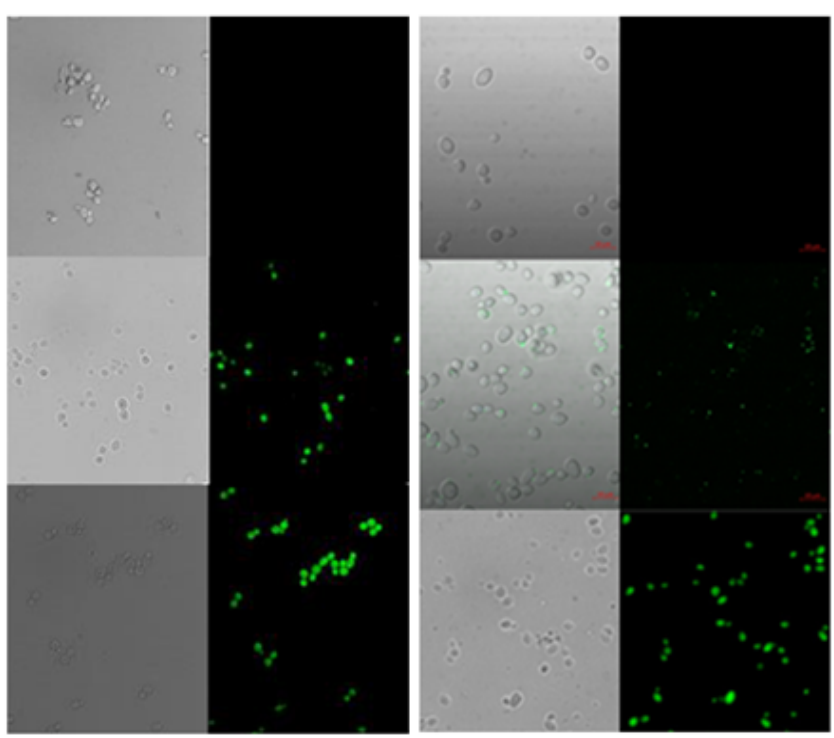

\section{C. krusei}

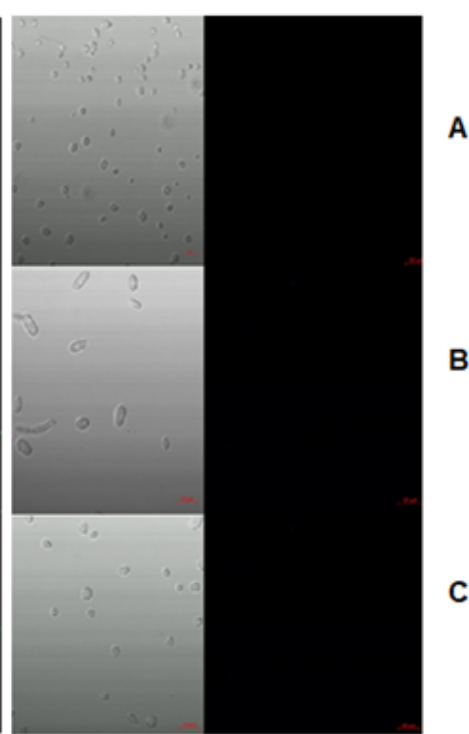

Figure 2. Cellular uptake of conjugate 27 by C. albicans, C. glabrata, and C. krusei cells. Cells grown in the RPMI-1640 medium were transferred to PBS, and the conjugate 27 was added at the final concentration of $50 \mu \mathrm{g} \mathrm{mL}^{-1}$. Samples of the cell suspension were collected at zero time (A), after $15 \mathrm{~min}(\mathbf{B})$, and $30 \mathrm{~min}(\mathbf{C})$; then, cells were harvested, washed extensively, and suspended in PBS. Images were taken with the fluorescence microscope at $\lambda_{\mathrm{exc}}=438 \mathrm{~nm}$. Bar represents $10 \mu \mathrm{m}$.
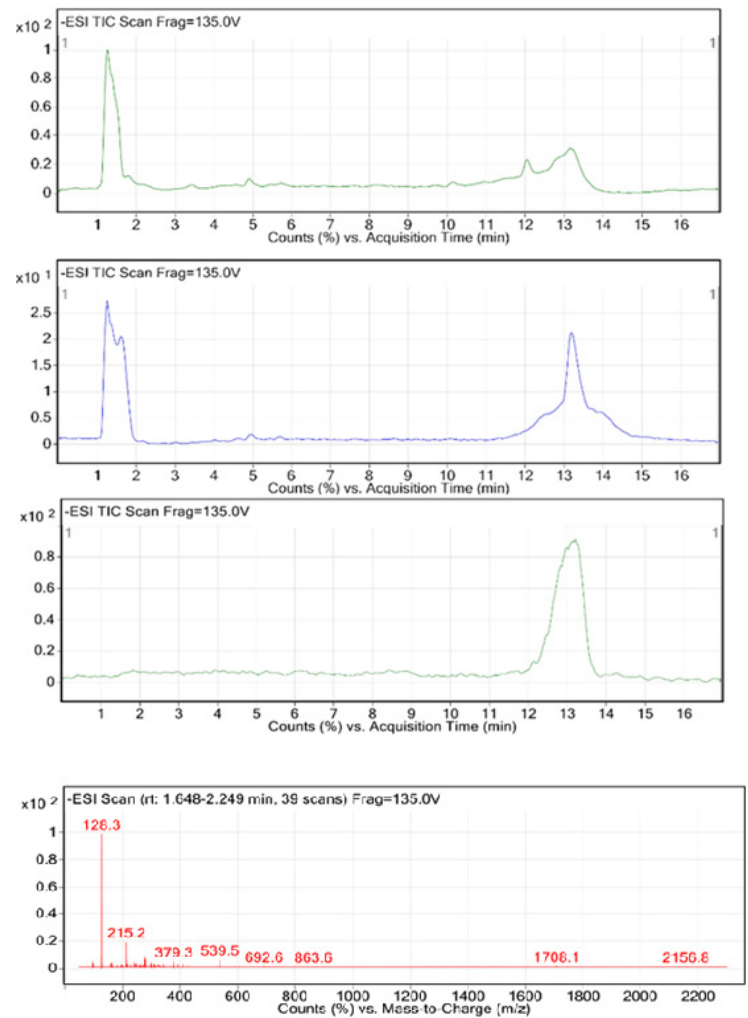

(A)

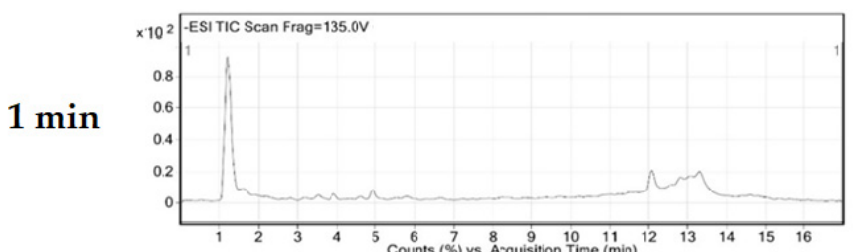

$10 \mathrm{~min}$

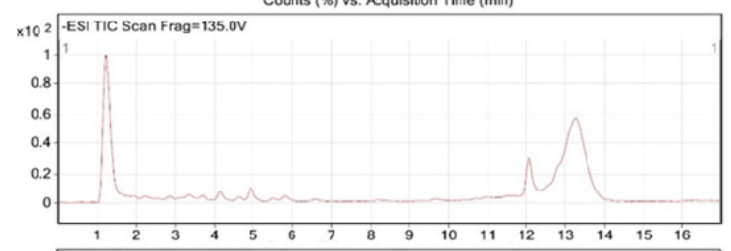

$20 \mathrm{~min}$
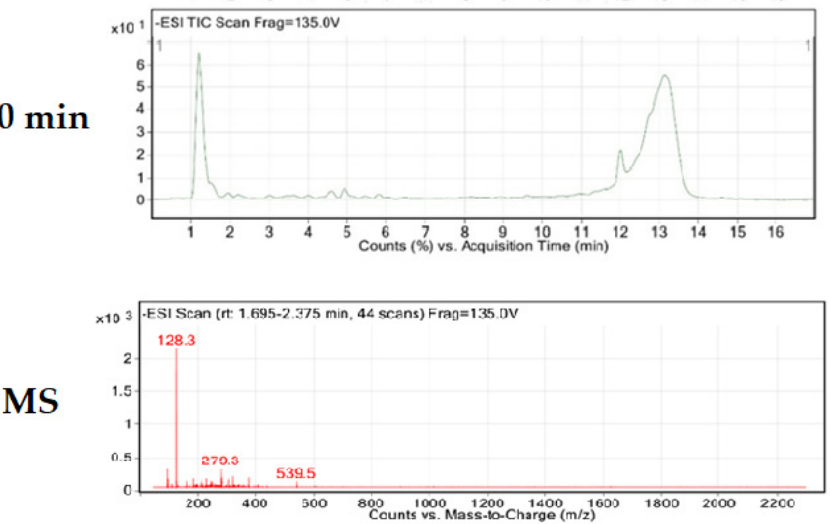

(B)

Figure 3. HPLC-MS analysis of composition of reaction mixtures resulting from the digestion of conjugate $24 \mathrm{c}$ (A) and 24d (B) with pig liver esterase. 
The analogous HPLC-MS analyses were performed for samples collected at time intervals from mixtures consisting of conjugates $24 \mathbf{a}-\mathbf{d}$ or 35 dissolved in the cell-free extract of $C$. albicans cells. Results of analyses of mixtures containing conjugates $24 \mathrm{c}$ and 24d are shown in Figure 4A,B.

Peaks with time-dependent increasing intensity, at locations roughly corresponding to those of the intact cispentacin, are present in both chromatograms. Surprisingly, in the MS spectra, there are not signals with $m / z=128.3$. Instead, the strong signals at $m / z=145.1$ or 145.2 are present. Most likely, these signals may be attributed to any cispentacin derivative formed in the cell-free extract. In the control experiment, cispentacin was incubated in the $C$. albicans cell-free extract, but the MS analysis did not reveal the formation of any compound with $m / z=145.1$ or 145.2 .

Neither cispentacin nor the $m / z 145.1 / 145.2$ compound was found in the reaction mixtures containing conjugates $\mathbf{2 4 a}, \mathbf{2 4} \mathbf{b}$, or $\mathbf{3 5}$. It may suggest that these conjugates are not cleaved in C. albicans cell-free extract.
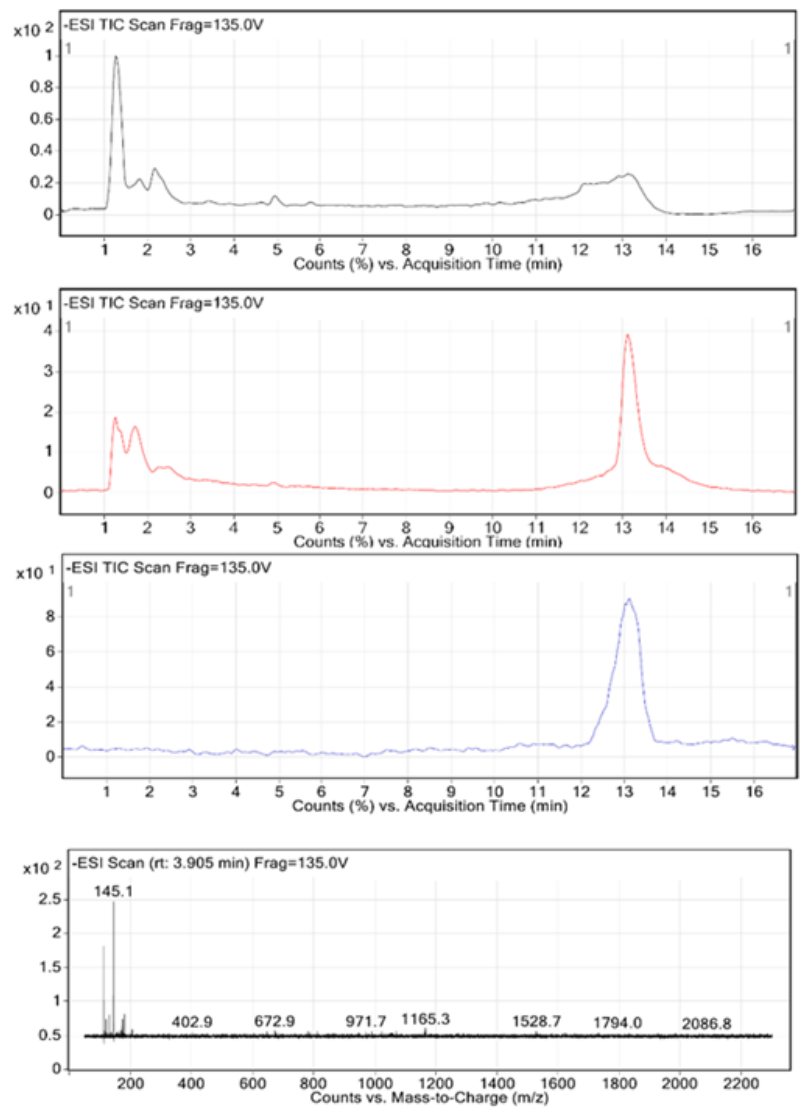

(A)
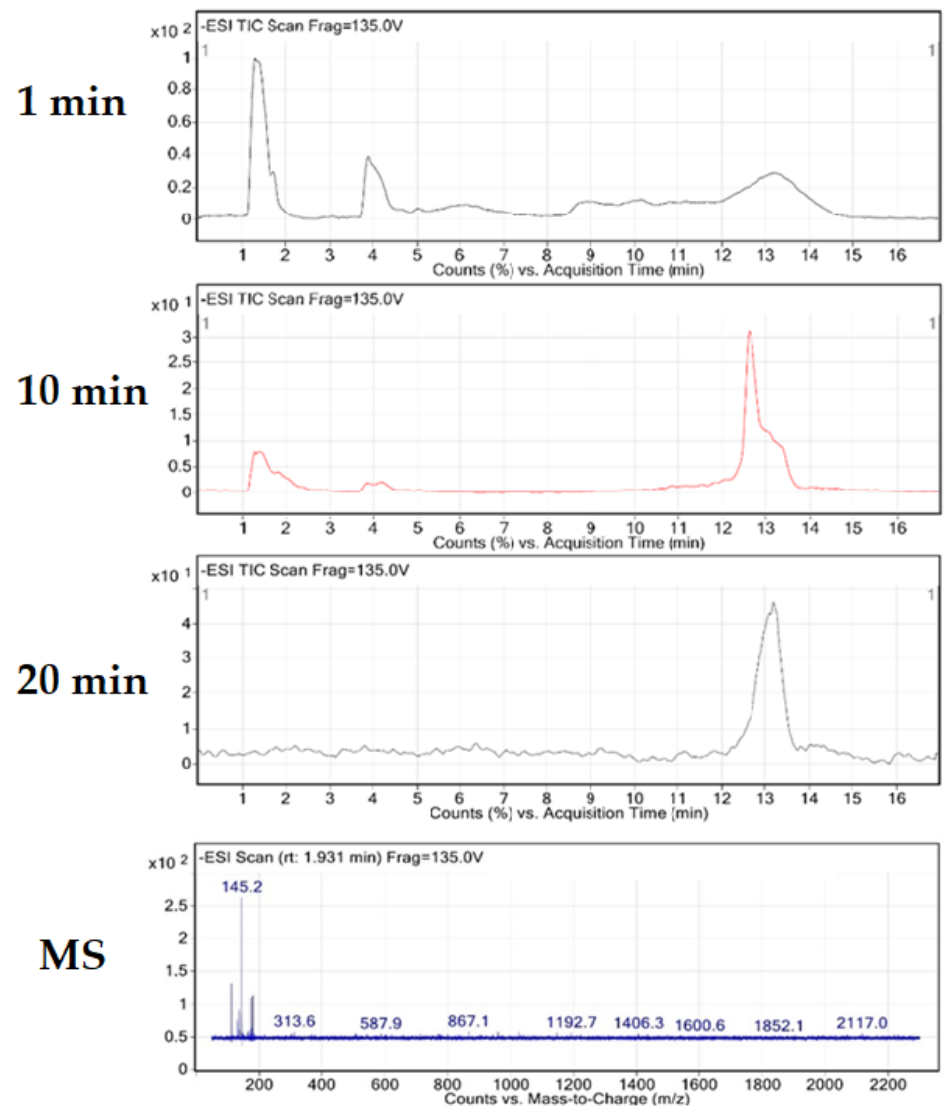

(B)

Figure 4. HPLC-MS analysis of composition of reaction mixtures resulting from the digestion of conjugate $24 \mathrm{c}$ (A) and 24d (B) in cell-free extract from C. albicans.

\section{Discussion}

Among the five rationally designed conjugates of a diwalled molecular umbrella with cispentacin, joined through the cleavable linker, only one, namely the TML-pimelate system containing 24c, exhibited antifungal in vitro activity in RPMI-1640 medium under CLSI-recommended conditions. Two analogs of this conjugate, containing the much shorter TML-succinate linker, 24a and $\mathbf{2 4 b}$, appeared active only in minimal YNB-AS medium, while conjugates $24 \mathrm{~d}$ and 35 (containing the $o$-dithiobenzylcarbamoyl linker) were inactive in both media. Lack of the antifungal activity of 35 in RPMI-1640 medium could be 
at least in part explained by the presence of reduced glutathione at $1 \mathrm{mg} \mathrm{L}^{-1}$ in this medium; however, YNB-AS does not contain any thiol compounds. Rather unexpectedly, conjugate 35 was not cleaved in the cytoplasmic extract of $C$. albicans, although cleavage was observed in the model system with $5 \mathrm{mM}$ glutathione. No cleavage in cell-free extract was also found for TML-containing conjugates $\mathbf{2 4 a}$ and $\mathbf{2 4 b}$. However, these conjugates were also found resistant to enzymatic cleavage by pig esterase in the model system. Most probably, the succinic acid link between spermidine scaffold and TML appeared to be short, and due to the close vicinity of the molecular umbrella-spermidine scaffold and TML, enzyme access to the ester bond in TML system is hindered. It seems that pimelic acid could be the optimal dicarboxylic linker joining the TML system with the spermidine scaffold. Conjugate 26d, containing suberic acid, which is only one methylene unit longer than pimelic acid, was not active as an antifungal, which was apparently due to the problems with internalization, since it was found cleavable in the cell-free extract. Notably, pimelate was previously found as the optimal linker in non-cleavable molecular umbrella-Amphotericin B conjugates [10].

Among the three Candida species tested, C. krusei appeared resistant to all conjugates, including 24c. Since conjugate 27, the fluorescent analogue of 24c, was not accumulated by $C$. krusei cells, one may suspect that $24 \mathrm{c}$ is also not taken up by these cells. We have no explanation for this phenomenon; nevertheless, it shows that the molecular umbrella may not by an universal molecular nanocarrier.

From the results of HPLC-MS analysis of metabolism of conjugates $24 \mathrm{c}$ and $24 \mathrm{~d}$ in $C$. albicans cell-free extract, it is clear that the product of a possible cleavage, with RT similar to that of cispentacin but with 17 D higher MW, was formed, while such a product was not observed when intact cispentacin was incubated in the $C$. albicans cell-free extract. In this context, it is worth mentioning that there have not been any previous reports on the possible modification of cispentacin in the cytosol of fungal cells. On the other hand, it was found that the close structural analogue of cispentacin, BAY 10-8888, known also as Icofungipen or PLD-118, was not metabolized by liver microsomes under in vitro conditions [20]. Undoubtedly, further studies are necessary to allow a correct interpretation of this finding, and any speculation on the identity of a possible cispentacin metabolite makes no sense.

So far, molecular umbrellas have been tested as possible molecular nanocarriers exclusively in liposomal or mammalian cell systems $[8,21]$ with no attempts concerning microbial, cell wall-containing cells. The presence of the cell wall surrounding the cytoplasmic membrane might theoretically constitute a physical barrier for molecules as large as molecular umbrellas and their conjugates. In this respect, it is worth mentioning that small but not large dendrimers were used as nanocarriers for some antimicrobials [22] and, on the other hand, tetra- and octawalled molecular umbrellas were not effective as components of conjugates with Amphotericin B [23]. Now, we have been able to demonstrate that at least conjugates incorporating a diwalled molecular umbrella are able to transgress this obstacle in Candida cells. This finding opens the possibility of further attempts aimed at the construction of other conjugates more active than those described in this work, possibly with cargo molecules other than cispentacin.

\section{Materials and Methods}

\subsection{Chemistry}

\subsubsection{General}

All solvents and reagents were used as obtained from commercial sources. ${ }^{1} \mathrm{H}$ NMR and ${ }^{13} \mathrm{C}$ NMR spectra were obtained at $500 \mathrm{MHz}$ Varian Unity Plus spectrometer, Varian Medical Systems, Darmstadt, Germany. and the deuterated solvents were used as internal locks. FTIR spectra were obtained with a Thermo Electron Nicolet 8700 spectrometer, Thermo Fisher Scientific, Waltham, MA, USA. High-resolution mass spectra were obtained using the Aqilent Technologies 6540 UHD Accurate-Mass Q-TOF LC/MS mass spectrometer, Waldbronn, Germany. Melting points were determined on a melting point 
apparatus equipped with a thermometer and were uncorrected. Column chromatography was performed with silica gel $(0.040-0.063 \mathrm{~mm})$ by using the indicated solvent systems. The following abbreviations are used in reporting NMR data: s-singlet, brs-broad singlet, $\mathrm{d}$-doublet, dd-doublet of doublets, $\mathrm{t}$ - triplet, q-quartet, qt—quintet.

\subsubsection{Syntheses}

Dicarboxylic Acid Anhydrides-General Procedure (1b,c), First, $19 \mathrm{mmol}$ of a dicarboxylic acid was dissolved in $50 \mathrm{~mL}$ of acetic anhydride and refluxed for $4 \mathrm{~h}$. The solvents were removed under reduced pressure, obtaining $18 \mathrm{mmol}$ of a cyclic anhydride.

Pimelic Anhydride 1b, Starting from $3 \mathrm{~g}$ (19 mmol) of pimelic acid, $2.64 \mathrm{~g}(18 \mathrm{mmol}$, $95 \%$ ) of pimelic anhydride $\mathbf{1 b}$ was obtained as a light-beige, low-melting solid. ${ }^{1} \mathrm{H}$ NMR $\left(500 \mathrm{MHz}, \mathrm{DMSO}-d_{6}\right) \delta: 2.50(\mathrm{t}, J=7.3 \mathrm{~Hz}, 4 \mathrm{H}), 1.55(\mathrm{qt}, J=7.4 \mathrm{~Hz}, 4 \mathrm{H}), 1.33(\mathrm{qt}, J=6.9 \mathrm{~Hz}$, $2 \mathrm{H}) .{ }^{13} \mathrm{C}$ NMR $\left(125 \mathrm{MHz}, \mathrm{DMSO}-d_{6}\right) \delta: 170.08,34.83,27.85,23.88$.

Suberic Anhydride 1c, Starting from $10 \mathrm{~g}(57 \mathrm{mmol})$ of suberic acid, $9 \mathrm{~g}(56 \mathrm{mmol}$, $98 \%$ ) of suberic anhydride $1 \mathrm{c}$ was obtained as a light-beige, low-melting solid. ${ }^{1} \mathrm{H}$ NMR $\left(500 \mathrm{MHz}, \mathrm{DMSO}-d_{6}\right) \delta: 2.49(\mathrm{t}, J=7.1 \mathrm{~Hz}, 4 \mathrm{H}), 1.56(\mathrm{~m}, 4 \mathrm{H}), 1.32(\mathrm{~m}, 4 \mathrm{H}) .{ }^{13} \mathrm{C}$ NMR $\left(125 \mathrm{MHz}, \mathrm{DMSO}-d_{6}\right) \delta: 169.66,34.47,28.22,24.03$.

Mono-tert-butyl esters (3a-c)-General Procedure, First, $20 \mathrm{mmol}$ of carboxylic acid anhydride, $2 \mathrm{mmol}$ of DMAP, and $5.88 \mathrm{mmol}$ of NHS were suspended in $75 \mathrm{~mL}$ of toluene. Subsequently, $40 \mathrm{mmol}$ of tert-butanol and $6 \mathrm{mmol}$ of TEA were added, and the resulting mixture was refluxed for $24 \mathrm{~h}$ in an oil bath. The mixture was cooled to room temperature; then, $75 \mathrm{~mL}$ of AcOEt was added. The resulting solution was washed with $1 \mathrm{M} \mathrm{HCl}_{(\mathrm{aq})}$ $(3 \times 70 \mathrm{~mL})$ and with brine $(3 \times 70 \mathrm{~mL})$, respectively. The organic layer was dried over anhydrous $\mathrm{MgSO}_{4}$, the desiccant was filtered off, and the filtrate was concentrated under reduced pressure. The residue was purified by liquid column chromatography or crystallization.

Mono-tert-butyl succinate 3a, Starting from $25.37 \mathrm{~g}(0.25 \mathrm{~mol})$ of succinic anhydride 1a, $21.1 \mathrm{~g}(0.12 \mathrm{~mol}, 48 \%)$ of monoester $3 \mathrm{a}$ was obtained as a white solid with m.p. $42-44{ }^{\circ} \mathrm{C}$ (AcOEt/hexanes). ${ }^{1} \mathrm{H}$ NMR (500 MHz, DMSO- $d_{6}$ ) $\delta: 12.13$ (brs, 1H), 2.38 (s, 4H), 1.39 (s, 9H). ${ }^{13} \mathrm{C}$ NMR (125 MHz, DMSO-d $\left.{ }_{6}\right) \delta: 173.67,171.88,80.08,30.24,29.10,27.31$.

Mono-tert-butyl pimelate $3 \mathrm{~b}$, Starting from $6 \mathrm{~g}(42.08 \mathrm{mmol})$ of pimelic anhydride $\mathbf{1 b}$, $5.25 \mathrm{~g}(24.27 \mathrm{mmol}, 58 \%)$ of monoester $3 \mathrm{~b}$ was obtained as a light-yellow oil with $\mathrm{R}_{\mathrm{f}} 0.67$ (hexanes / AcOEt, 4/6, v/v). ${ }^{1} \mathrm{H}$ NMR (500 MHz, DMSO-d 6 ) $\delta: 11.98$ (brs, 1H), 2.18 (m, 4H), $1.50(\mathrm{~m}, 4 \mathrm{H}), 1.40(\mathrm{~s}, 9 \mathrm{H}), 1.27(\mathrm{~m}, 2 \mathrm{H}) .{ }^{13} \mathrm{C}$ NMR $\left(125 \mathrm{MHz}, \mathrm{DMSO}-d_{6}\right) \delta: 174.86,172.79$, 79.97, 35.08, 34.05, 28.42, 28.22, 24.80, 24.64.

Mono-tert-butyl suberate 3c, Starting from $9 \mathrm{~g}(58 \mathrm{mmol})$ of suberic anhydride $\mathbf{1 c}$, $3.23 \mathrm{~g}$ (14.03 mmol, $24 \%)$ of monoester $3 \mathrm{c}$ was obtained as colorless oil with $\mathrm{R}_{\mathrm{f}} 0.63$ (hexanes/AcOEt/AcOH, 80/20/1,v/v/v). ${ }^{1} \mathrm{H}$ NMR (500 MHz, DMSO- $\left.d_{6}\right) \delta: 11.97$ (brs, $1 \mathrm{H}), 2.17(\mathrm{~m}, 4 \mathrm{H}), 1.47(\mathrm{~m}, 4 \mathrm{H}), 1.39(\mathrm{~s}, 9 \mathrm{H}), 1.25(\mathrm{~m}, 4 \mathrm{H}) .{ }^{13} \mathrm{C}$ NMR $\left(125 \mathrm{MHz}, \mathrm{DMSO}-d_{6}\right) \delta$ : $174.96,172.60,79.63,35.14,34.00,28.64,28.54,28.20,24.90,24.78$.

4,4,5,7-tetramethylchroman-2-one 6, To a mixture of $22.21 \mathrm{~g}(0.18 \mathrm{~mol})$ of 3,5-dimethylphenol 5 dissolved in $40 \mathrm{~mL}$ of methanesulfonic acid, $23 \mathrm{~g}(0.20 \mathrm{~mol})$ of methyl 3-methylbut-2enoate 4 was added in one portion. The reaction mixture was stirred and heated at a $70{ }^{\circ} \mathrm{C}$ in an oil bath for $18 \mathrm{~h}$. The mixture was cooled to room temperature, poured into $400 \mathrm{~mL}$ of cold water, and extracted with ethyl acetate $(3 \times 150 \mathrm{~mL})$. The organic layer was washed with water $(3 \times 150 \mathrm{~mL})$, saturated $\mathrm{NaHCO}_{3(\mathrm{aq})}(3 \times 150 \mathrm{~mL})$, and water $(2 \times 150 \mathrm{~mL})$, respectively. The acetate layer was dried over anhydrous $\mathrm{MgSO}_{4}$, the desiccant was removed, and the filtrate was concentrated under reduced pressure. The residue was recrystallized from diethyl ether obtaining $33.12 \mathrm{~g}(0.16 \mathrm{~mol}, 90 \%)$ of product 6 as colorless crystals, with m.p. 88-91 ${ }^{\circ} \mathrm{C}$ and $\mathrm{R}_{\mathrm{f}} 0.35$ (hexanes / AcOEt, 9/1, v/v). ${ }^{1} \mathrm{H} \mathrm{NMR}(500 \mathrm{MHz}$, DMSO- $\left.d_{6}\right) \delta: 6.78(\mathrm{~s}, 1 \mathrm{H}), 6.72(\mathrm{~s}, 1 \mathrm{H}), 2.65(\mathrm{~s}, 2 \mathrm{H}), 2.42(\mathrm{~s}, 3 \mathrm{H}), 2.21(\mathrm{~s}, 3 \mathrm{H}), 1.34(\mathrm{~s}, 6 \mathrm{H}) .{ }^{13} \mathrm{C}$ NMR (125 MHz, DMSO-d $\left.d_{6}\right) \delta: 168.35,151.79,137.28,136.29,129.46,127.34,115.75,45.00$, 35.06, 27.57, 23.00, 20.35. FTIR $v\left(\mathrm{~cm}^{-1}\right): 3050,2900,1775,1625,1575$. 
2-(3-hydroxy-1,1-dimethylpropyl)-3,5-dimethylphenol 7, To a stirred suspension of $4 \mathrm{~g}$ $(0.104 \mathrm{~mol})$ of $\mathrm{LiAlH}_{4}$ in $100 \mathrm{~mL}$ of dry THF, $5.3 \mathrm{~g}(26 \mathrm{mmol})$ of lactone 6 was added in small portions. Once the addition was completed, the reaction mixture was stirred at room temperature for $3 \mathrm{~h}$. The excess of unreacted $\mathrm{LiAlH}_{4}$ was decomposed by adding AcOEt, $\mathrm{MeOH}$, and water, respectively. The slurry was filtered off under reduced pressure, and the filtrate was concentrated under reduced pressure. The residue was dissolved in $100 \mathrm{~mL}$ of dichloromethane and dried over anhydrous $\mathrm{MgSO}_{4}$. After the removal of desiccant and concentration of filtrate under reduced pressure, the residue was recrystallized from dichloromethane. Obtained $3.47 \mathrm{~g}(17 \mathrm{mmol}, 65 \%)$ of product 7 as colorless crystals, with m.p. $112-114{ }^{\circ} \mathrm{C}$ and $\mathrm{R}_{\mathrm{f}} 0.27$ (hexanes/AcOEt, $\left.7 / 3, v / v\right)$. ${ }^{1} \mathrm{H}$ NMR (500 MHz, DMSO- $d_{6}$ ) $\delta: 8.96(\mathrm{~s}, 1 \mathrm{H}), 6.43(\mathrm{~s}, 1 \mathrm{H}), 6.28(\mathrm{~s}, 1 \mathrm{H}), 4.11(\mathrm{t}, J=4.9 \mathrm{~Hz}, 1 \mathrm{H}), 3.20(\mathrm{~m}, 2 \mathrm{H}), 2.35(\mathrm{~s}, 3 \mathrm{H})$, $2.07(\mathrm{~s}, 3 \mathrm{H}), 2.04(\mathrm{t}, J=7.9 \mathrm{~Hz}, 2 \mathrm{H}), 1.44(\mathrm{~s}, 6 \mathrm{H}) .{ }^{13} \mathrm{C}$ NMR $\left(125 \mathrm{MHz}, \mathrm{DMSO}-d_{6}\right) \delta: 157.42$, $137.25,135.16,128.95,125.79,116.22,59.59,45.23,40.00,32.34,25.98,20.58$.

2-\{3-[(O-tert-butyldimethylsilyl)hydroxy]-1,1-dimethylpropyl\}-3,5-dimethylphenol 8, The reaction was carried out under argon atmosphere. To an ice-cold stirred mixture of $250 \mathrm{mg}(1.2 \mathrm{mmol})$ of phenol $7 \mathrm{and} 244 \mathrm{mg}(2 \mathrm{mmol})$ of DMAP, dissolved in $10 \mathrm{~mL}$ of dry dichloromethane, $217 \mathrm{mg}$ (1.44 mmol) of TBDMSCl in $10 \mathrm{~mL}$ of dry dichloromethane was added dropwise. The mixture was stirred in an ice bath for $2 \mathrm{~h}$ and then for $3 \mathrm{~h}$ at room temperature. Subsequently, the mixture was washed with water $(2 \times 10 \mathrm{~mL}), 5 \%$ solution of $\mathrm{NaHCO}_{3(\mathrm{aq})}(3 \times 10 \mathrm{~mL})$, and water $(2 \times 10 \mathrm{~mL})$, respectively. The organic layer was dried over anhydrous $\mathrm{MgSO}_{4}$, the desiccant was filtered off, and the filtrate was concentrated under reduced pressure. The residue was recrystallized from dichloromethane, obtaining $400 \mathrm{mg}(1.2 \mathrm{mmol}, 100 \%)$ of product 8 as white crystals, with m.p. $106-109^{\circ} \mathrm{C}$ and $\mathrm{R}_{\mathrm{f}} 0.52$ (hexanes/AcOEt, 9/1, v/v). ${ }^{1} \mathrm{H}$ NMR (500 MHz, DMSO- $\left.d_{6}\right) \delta: 8.99(\mathrm{~s}, 1 \mathrm{H}), 6.43(\mathrm{~s}, 1 \mathrm{H}), 6.28$ $(\mathrm{s}, 1 \mathrm{H}), 3.39(\mathrm{t}, J=7.4 \mathrm{~Hz}, 2 \mathrm{H}), 2.36(\mathrm{~s}, 3 \mathrm{H}), 2.09(\mathrm{~m}, 2 \mathrm{H}), 2.05(\mathrm{~s}, 3 \mathrm{H}), 1.42(\mathrm{~s}, 6 \mathrm{H}), 0.79(\mathrm{~s}$, $9 \mathrm{H}),-0.08(\mathrm{~s}, 6 \mathrm{H}) .{ }^{13} \mathrm{C}$ NMR $\left(125 \mathrm{MHz}, \mathrm{DMSO}-d_{6}\right) \delta: 157.25,137.27,134.91,128.29,125.93$, $115.85,61.50,45.50,32.37,26.44,25.86,20.68,18.15,-4.71$.

2-\{3-[(O-tert-butyldimethylsilyl)hydroxy]-1,1-dimethylpropyl\}-O'-acyloyl-3,5-dimethylphenol $(9 \mathbf{a}-\mathbf{c})$-General Procedure, A stirred mixture of $15.5 \mathrm{mmol}$ of phenol, $23.5 \mathrm{mmol}$ of carboxylic acid, and $2.05 \mathrm{mmol}$ of DMAP in $100 \mathrm{~mL}$ of dry dichloromethane was cooled in an ice bath to $0{ }^{\circ} \mathrm{C}$, and then, $30.5 \mathrm{mmol}$ of DCC dissolved in $20 \mathrm{~mL}$ of dry dichloromethane was added dropwise. The mixture was stirred at room temperature for $48 \mathrm{~h}$. The precipitate of DCU was filtered off, and the filtrate was concentrated under reduced pressure. The residue was dissolved in $100 \mathrm{~mL}$ of chloroform and washed with saturated $\mathrm{NaHCO}_{3(\mathrm{aq})}$ $(2 \times 50 \mathrm{~mL}), 5 \% \mathrm{NaHSO}_{4(\mathrm{aq})}(2 \times 50 \mathrm{~mL})$, and water $(2 \times 50 \mathrm{~mL})$, respectively. The organic layer was dried over anhydrous $\mathrm{MgSO}_{4}$, the desiccant was filtered off, and the filtrate was concentrated under reduced pressure. The residue was purified by liquid column chromatography, using a mixture of solvents hexanes/AcOEt, $9 / 1, v / v$ as a mobile phase.

tert-Butyl-2-\{3-[(O-tert-butyldimethylsilyl)hydroxy]-1,1-dimethylpropyl\}-3,5-dimethylphenyl succinate $9 \mathrm{a}$, Starting from $810 \mathrm{mg}(4.65 \mathrm{mmol})$ of carboxylic acid 3a and $1 \mathrm{~g}(3.1 \mathrm{mmol})$ of phenol 8, $1.41 \mathrm{~g}(2.94 \mathrm{mmol}, 95 \%)$ of ester $9 \mathrm{a}$ was obtained as a colorless oil. $\mathrm{R}_{\mathrm{f}} 0.52$ (hexanes/AcOEt, 9/1, $v / v$ ). HRMS-ESI: $m / z$ calcd. for $\mathrm{C}_{27} \mathrm{H}_{46} \mathrm{O}_{5} \mathrm{Si} 478.3115$; found 479.3251 $[\mathrm{M}+1]^{+} .{ }^{1} \mathrm{H}$ NMR $\left(500 \mathrm{MHz}, \mathrm{DMSO}-d_{6}\right) \delta: 6.82(\mathrm{~s}, 1 \mathrm{H}), 6.55(\mathrm{~s}, 1 \mathrm{H}), 3.42(\mathrm{t}, J=7.2 \mathrm{~Hz}, 2 \mathrm{H})$, $2.75(\mathrm{t}, J=6.7 \mathrm{~Hz}, 2 \mathrm{H}), 2.56(\mathrm{t}, J=6.3 \mathrm{~Hz}, 2 \mathrm{H}), 2.48(\mathrm{~s}, 3 \mathrm{H}), 2.17(\mathrm{~s}, 2 \mathrm{H}), 1.96(\mathrm{t}, J=7.2 \mathrm{~Hz}$, $2 \mathrm{H}), 1.41(\mathrm{~s}, 6 \mathrm{H}), 1.39(\mathrm{~s}, 9 \mathrm{H}), 0.81(\mathrm{~s}, 9 \mathrm{H}),-0.06(\mathrm{~s}, 6 \mathrm{H}) .{ }^{13} \mathrm{C}$ NMR $(125 \mathrm{MHz}$, DMSO-d 6 ) $\delta:$ $171.74,171.44,150.06,138.24,135.58,134.00,132.25,123.37,80.45,60.83,46.02,39.17,32.05$, $30.07,28.15,26.23,25.15,20.01,18.08,-4.87$.

tert-Butyl-2-\{3-[(O-tert-butyldimethylsilyl)hydroxy]-1,1-dimethylpropyl\}-3,5-dimethylphenyl pimelate $9 \mathbf{b}$, Starting from $2.67 \mathrm{~g}(12 \mathrm{mmol})$ of carboxylic acid $3 \mathbf{b}$ and $2.58 \mathrm{~g}(8 \mathrm{mmol})$ of phenol 8, $3.40 \mathrm{~g}(6.52 \mathrm{mmol}, 82 \%)$ of ester $9 \mathrm{~b}$ was obtained as a colorless oil. $\mathrm{R}_{\mathrm{f}} 0.50$ (hexanes/AcOEt, 9/1, $v / v$ ). HRMS-ESI: $m / z$ calcd. for $\mathrm{C}_{30} \mathrm{H}_{52} \mathrm{O}_{5} \mathrm{Si}$ 520.3584; found $521.3579[\mathrm{M}+1]^{+} .{ }^{1} \mathrm{H}$ NMR (500 MHz, DMSO-d $\left.d_{6}\right) \delta: 6.83(\mathrm{~s} 1 \mathrm{H}), 6.58(\mathrm{~s}, 1 \mathrm{H}), 3.42(\mathrm{t}$, $J=7.4 \mathrm{~Hz}, 2 \mathrm{H}), 2.54(\mathrm{~m}, 2 \mathrm{H}), 2.48(\mathrm{~s}, 3 \mathrm{H}), 2.21(\mathrm{~m}, 2 \mathrm{H}), 2.18(\mathrm{~s}, 3 \mathrm{H}), 1.95(\mathrm{t}, J=7.5 \mathrm{~Hz}, 2 \mathrm{H})$, $1.63(\mathrm{qt}, J=7.5 \mathrm{~Hz}, 2 \mathrm{H}), 1.54(\mathrm{qt}, J=7.4 \mathrm{~Hz}, 2 \mathrm{H}), 1.40(\mathrm{~m}, 17 \mathrm{H}), 0.81(\mathrm{~s}, 9 \mathrm{H}),-0.06(\mathrm{~s}, 6 \mathrm{H})$. 
${ }^{13} \mathrm{C}$ NMR (125 MHz, DMSO- $\left.d_{6}\right) \delta: 172.57,172.44,150.09,138.19,135.77,134.12,132.18$, $123.59,79.86,79.69,60.63,45.94,39.15,35.03,34.49,32.05,28.31,28.21,26.23,25.30,24.76$, $24.26,20.12,18.29$.

tert-Butyl-2-\{3-[(O-tert-butyldimethylsilyl)hydroxy]-1,1-dimethylpropyl\}-3,5-dimethylphenyl suberate 9c, Starting from $3.09 \mathrm{~g}(13.40 \mathrm{mmol})$ of carboxylic acid $3 \mathrm{c}$ and $3.60 \mathrm{~g}(11.16 \mathrm{mmol})$ of phenol 8, $4.82 \mathrm{~g}(9.01 \mathrm{mmol}, 81 \%)$ of ester $9 \mathrm{c}$ was obtained as a colorless oil. $\mathrm{R}_{\mathrm{f}} 0.64$ (hexanes / AcOEt, 9/1, v/v). HRMS-ESI: $m / z$ calcd. for $\mathrm{C}_{31} \mathrm{H}_{54} \mathrm{O}_{5} \mathrm{Si} 534.3741$; found 535.3743 $[\mathrm{M}+1]^{+} .{ }^{1} \mathrm{H}$ NMR $\left(500 \mathrm{MHz}, \mathrm{DMSO}-d_{6}\right) \delta: 6.81(\mathrm{~s}, 1 \mathrm{H}), 6.56(\mathrm{~s}, 1 \mathrm{H}), 3.40(\mathrm{t}, J=7.3 \mathrm{~Hz}, 2 \mathrm{H})$, $2.52(\mathrm{~m}, 2 \mathrm{H}), 2.46(\mathrm{~s}, 3 \mathrm{H}), 2.17(\mathrm{~s}, 3 \mathrm{H}), 1.93(\mathrm{t}, J=7.3 \mathrm{~Hz}, 2 \mathrm{H}), 1.62(\mathrm{qt}, J=7.2 \mathrm{~Hz}, 2 \mathrm{H}), 1.50$ $(\mathrm{qt}, J=7.5 \mathrm{~Hz}, 2 \mathrm{H}), 1.39(\mathrm{~m}, 15 \mathrm{H}), 1.35-1.09(\mathrm{~m}, 6 \mathrm{H}), 0.78(\mathrm{~s}, 9 \mathrm{H}),-0.06(\mathrm{~s}, 6 \mathrm{H}) .{ }^{13} \mathrm{C} \mathrm{NMR}$ $\left(125 \mathrm{MHz}, \mathrm{DMSO}-d_{6}\right) \delta: 172.63,172.50,150.04,138.15,135.76,134.07,132.21,123.64,79.71$, $60.55,45.81,39.15,35.13,34.45,32.01,28.52,28.20,27.80,26.21,25.80,25.32,24.79,24.35$, $20.13,18.18,-5.02$.

2-(3-hydroxy-1,1-dimethylpropyl\}-O'-acyloyl-3,5-dimethylphenol (10a-c)_General Procedure, The silyl ether was dissolved in $200 \mathrm{~mL}$ of a mixture of $\mathrm{THF} / \mathrm{H}_{2} \mathrm{O} / \mathrm{AcOH}, 1 / 1 / 3$, $v / v / v$ and stirred at room temperature for $3 \mathrm{~h}$. The solvent was evaporated under reduced pressure. The residue was dissolved in $100 \mathrm{~mL}$ of AcOEt and washed with water $(30 \mathrm{~mL})$, saturated $\mathrm{NaHCO}_{3(\mathrm{aq})}(3 \times 30 \mathrm{~mL})$, and water $(3 \times 30 \mathrm{~mL})$, respectively. The organic layer was dried over anhydrous $\mathrm{MgSO}_{4}$, the desiccant was filtered off, and the filtrate was concentrated under reduced pressure. The residue was purified by liquid column chromatography, using a mixture of solvents hexanes/AcOEt, 7/3, $v / v$ as a mobile phase.

tert-Butyl-2-(3-hydroxy-1,1-dimethylpropyl)-3,5-dimethylphenyl succinate 10a, Starting from $204 \mathrm{mg}(0.43 \mathrm{mmol})$ of ester $9 \mathrm{a}, 112 \mathrm{mg}(0.31 \mathrm{mmol}, 72 \%)$ of alcohol 10a was obtained as a colorless oil. $\mathrm{R}_{\mathrm{f}} 0.41$ (hexanes / AcOEt, 7/3, v/v). HRMS-ESI: $m / z$ calcd. for $\mathrm{C}_{21} \mathrm{H}_{32} \mathrm{O}_{5}$ 364.2251; found 365.2580 [M + 1] ${ }^{+}$. ${ }^{1} \mathrm{H}$ NMR (500 MHz, DMSO- $\left.d_{6}\right) \delta: 6.81(\mathrm{~s}, 1 \mathrm{H}), 6.54(\mathrm{~s}$, $1 \mathrm{H}), 4.20(\mathrm{t}, J=5 \mathrm{~Hz}, 1 \mathrm{H}), 3.20(\mathrm{~m}, 2 \mathrm{H}), 2.76(\mathrm{t}, J=6.6 \mathrm{~Hz}, 2 \mathrm{H}), 2.55(\mathrm{t}, J=6.3 \mathrm{~Hz}, 2 \mathrm{H}), 2.48$ $(\mathrm{s}, 3 \mathrm{H}), 2.15(\mathrm{~s}, 3 \mathrm{H}), 1.90(\mathrm{t}, J=7.7 \mathrm{~Hz}, 2 \mathrm{H}), 1.40(\mathrm{~s}, 9 \mathrm{H}), 1.39(\mathrm{~s}, 6 \mathrm{H}) .{ }^{13} \mathrm{C} \mathrm{NMR}(125 \mathrm{MHz}$, DMSO- $d_{6}$ ) $\delta: 171.25,170.92,149.28,137.73,135.04,133.79,131.55,122.79,79.78,58.06,45.43$, $38.41,31.30,29.68,27.48,24.58,19.37$.

tert-Butyl-2-(3-hydroxy-1,1-dimethylpropyl\}-3,5-dimethylphenyl pimelate $\mathbf{1 0 b}$, Starting from $3.40 \mathrm{~g}(6.52 \mathrm{mmol})$ of ester $9 \mathrm{~b}, 1.40 \mathrm{~g}(3.44 \mathrm{mmol}, 53 \%)$ of alcohol $10 \mathrm{~b}$ was obtained as a colorless oil. $\mathrm{R}_{\mathrm{f}} 0.46$ (hexanes/AcOEt, $7 / 3, v / v$ ). HRMS-ESI: $m / z$ calcd. for $\mathrm{C}_{24} \mathrm{H}_{38} \mathrm{O}_{5}$ 406.2790; found 407.2789 [M + 1] ${ }^{+} .{ }^{1} \mathrm{H} \mathrm{NMR}\left(500 \mathrm{MHz}, \mathrm{CDCl}_{3}\right) \delta: 6.81(\mathrm{~s}, 1 \mathrm{H}), 6.52(\mathrm{~s}, 1 \mathrm{H})$, $3.53(\mathrm{t}, J=6.9 \mathrm{~Hz}, 2 \mathrm{H}), 2.55(\mathrm{t}, J=7.4 \mathrm{~Hz}, 2 \mathrm{H}), 2.52(\mathrm{~s}, 3 \mathrm{H}), 2.24(\mathrm{t}, J=7.3 \mathrm{~Hz}, 2 \mathrm{H}), 2.22(\mathrm{~s}$, $3 \mathrm{H}), 2.04(\mathrm{t}, J=7.4 \mathrm{~Hz}, 2 \mathrm{H}), 1.77(\mathrm{qt}, J=7.5 \mathrm{~Hz}, 2 \mathrm{H}), 1.64(\mathrm{qt}, J=7.7 \mathrm{~Hz}, 2 \mathrm{H}), 1.48(\mathrm{~s}, 6 \mathrm{H})$, 1.46-1.38 (m, 11H). ${ }^{13} \mathrm{C}$ NMR $\left(125 \mathrm{MHz} \mathrm{CDCl}_{3}\right) \delta: 168.41,168.27,145.02,133.71,131.42$, $129.05,127.73,118.52,75.40,55.76,41.01,34.37,30.58,30.09$, 27.27, 23.86, 23.37, 20.58, 19.99, $19.60,15.42$.

tert-Butyl-2-(3-hydroxy-1,1-dimethylpropyl)-3,5-dimethylphenyl suberate 10c, Starting from $4.82 \mathrm{~g}(9.01 \mathrm{mmol})$ of ester $9 \mathrm{c}, 3.25 \mathrm{~g}(7.72 \mathrm{mmol}, 86 \%)$ of alcohol 10c was obtained as a colorless oil. $\mathrm{R}_{\mathrm{f}} 0.50$ (hexanes/AcOEt, 7/3, v/v). HRMS-ESI: $m / z$ calcd. for $\mathrm{C}_{25} \mathrm{H}_{40} \mathrm{O}_{5}$ 420.2876; found $421.2875[\mathrm{M}+1]^{+} .{ }^{1} \mathrm{H} \mathrm{NMR}\left(500 \mathrm{MHz}, \mathrm{CDCl}_{3}\right) \delta: 6.84(\mathrm{~s}, 1 \mathrm{H}), 6.54(\mathrm{~s}, 1 \mathrm{H})$, $3.56(\mathrm{t}, J=7.3 \mathrm{~Hz}, 2 \mathrm{H}), 2.56(\mathrm{~m}, 5 \mathrm{H}), 2.22(\mathrm{~m}, 6 \mathrm{H}), 2.07(\mathrm{t}, J=7.1 \mathrm{~Hz}, 2 \mathrm{H}), 1.78(\mathrm{qt}, J=7.6 \mathrm{~Hz}$, $2 \mathrm{H}), 1.63(\mathrm{qt}, J=7.4 \mathrm{~Hz}, 2 \mathrm{H}), 1.49(\mathrm{~s}, 6 \mathrm{H}), 1.45(\mathrm{~s}, 9 \mathrm{H}), 1.41(\mathrm{~m}, 4 \mathrm{H}) .{ }^{13} \mathrm{C} \mathrm{NMR}(125 \mathrm{MHz}$, $\left.\mathrm{CDCl}_{3}\right) \delta: 174.14,173.67,155.42,137.84,135.95,128.08,126.93,116.11,80.39,633.25,40.81$, 39.66, 35.51, 34.336, 31.64, 28.67, 28.61, 28.12, 25.60, 24.87, 24.733, 20.24.

2-(3-oxo-1,1-dimethylpropyl\}-O-acyloyl-3,5-dimethylphenol-General Procedure (11a-c), The reaction was carried out under argon atmosphere. To a stirred solution of $8.55 \mathrm{mmol}$ of alcohol dissolved in $100 \mathrm{~mL}$ of dry dichloromethane, $17.2 \mathrm{mmol}$ of PCC was added in one portion. The reaction mixture was stirred at room temperature for $4 \mathrm{~h}$ and then was filtered through silica gel using a mixture of hexane/AcOEt, $7 / 3, v / v$ as eluent.

tert-Butyl-2-(3-hydroxy-1,1-dimethylpropyl\}-3,5-dimethylphenyl succinate 11a, Starting from $429 \mathrm{mg}$ (1.18 mmol) of alcohol 10a, $362 \mathrm{mg}(1 \mathrm{mmol}, 85 \%)$ of aldehyde 11a was obtained as a light-yellow oil. $\mathrm{R}_{\mathrm{f}} 0.33$ (hexanes/AcOEt, 9/1, v/v). HRMS-ESI: $\mathrm{m} / \mathrm{z}$ calcd. 
for $\mathrm{C}_{21} \mathrm{H}_{30} \mathrm{O}_{5}$ 362.2091; found $363.2430[\mathrm{M}+1]^{+} .{ }^{1} \mathrm{H}$ NMR (500 MHz, DMSO- $\left.d_{6}\right) \delta: 9.44(\mathrm{t}$, $J=2.3 \mathrm{~Hz}, 1 \mathrm{H}), 6.85(\mathrm{~s}, 1 \mathrm{H}), 6.58(\mathrm{~s}, 1 \mathrm{H}), 2.88(\mathrm{~d}, J=2.1 \mathrm{~Hz}, 2 \mathrm{H}), 2.77(\mathrm{t}, J=6.6 \mathrm{~Hz}, 2 \mathrm{H}), 2.55$ $(\mathrm{t}, J=6.6 \mathrm{~Hz}, 2 \mathrm{H}), 2.48(\mathrm{~s}, 3 \mathrm{H}), 2.17(\mathrm{~s}, 3 \mathrm{H}), 1.47(\mathrm{~s}, 6 \mathrm{H}), 1.38(\mathrm{~s}, 9 \mathrm{H}) .{ }^{13} \mathrm{C} \mathrm{NMR}(125 \mathrm{MHz}$, DMSO- $\left.d_{6}\right) \delta: 202.74,171.99,171.61,149.60,138.10,136.12,133.51,132.17,123.56,80.59,56.31$, $37.96,31.40,30.10,28.09,25.19,19.90$.

tert-Butyl-2-(3-hydroxy-1,1-dimethylpropyl)-3,5-dimethylphenyl pimelate $\mathbf{1 1 b}$, Starting from $1.40 \mathrm{~g}$ (3.44 mmol) of alcohol 10b, $1.35 \mathrm{~g}$ (3.34 mmol, 97\%) of aldehyde $\mathbf{1 1} \mathbf{b}$ was obtained as a light-yellow oil. $\mathrm{R}_{\mathrm{f}} 0.32$ (hexanes / AcOEt, 9/1, v/v). HRMS-ESI: $m / z$ calcd. for $\mathrm{C}_{24} \mathrm{H}_{36} \mathrm{O}_{5}$ 404.2563; found 405.2559 [M + 1] $]^{+}$. ${ }^{1} \mathrm{H}$ NMR (500 MHz, DMSO- $\left.d_{6}\right) \delta: 9.45(\mathrm{t}, J=2.4 \mathrm{~Hz}$, $1 \mathrm{H}), 6.86(\mathrm{~s}, 1 \mathrm{H}), 6.61(\mathrm{~s}, 1 \mathrm{H}), 2.81(\mathrm{~d}, J=2.2 \mathrm{~Hz}, 2 \mathrm{H}), 2.57(\mathrm{t}, J=7.1 \mathrm{~Hz}, 2 \mathrm{H}), 2.50(\mathrm{~s}, 3 \mathrm{H})$, $2.21(\mathrm{t}, J=7.1 \mathrm{~Hz}, 2 \mathrm{H}), 2.18(\mathrm{~s}, 3 \mathrm{H}), 1.64(\mathrm{qt}, J=7.3 \mathrm{~Hz}, 2 \mathrm{H}), 1.54(\mathrm{qt}, J=7.6 \mathrm{~Hz}, 2 \mathrm{H}), 1.49$ (s, $6 \mathrm{H}), 1.45-1.30(\mathrm{~m}, 11 \mathrm{H}) .{ }^{13} \mathrm{C}$ NMR (125 MHz, DMSO-d 6 ) $\delta: 203.08,172.94,149.63,138.21$, $136.30,133.61,132.56,123.63,79.90,56.66,38.15,35.03,34.45,31.55,28.30,28.23,25.33,24.74$, $24.27,20.14$.

tert-Butyl-2-(3-hydroxy-1,1-dimethylpropyl\}-3,5-dimethylphenyl suberate 11c, Starting from $3.25 \mathrm{~g}$ (7.72 mmol) of alcohol 10c, $2.92 \mathrm{~g}(6.98 \mathrm{mmol}, 90 \%)$ of aldehyde 11c was obtained as a light-yellow oil. $\mathrm{R}_{\mathrm{f}} 0.37$ (hexanes / AcOEt, 9/1, $v / v$ ). HRMS-ESI: $m / z$ calcd. for $\mathrm{C}_{25} \mathrm{H}_{38} \mathrm{O}_{5}$ 418.2719; found 419.2721 [M + 1] ${ }^{+} .{ }^{1} \mathrm{H}$ NMR (500 MHz, DMSO- $\left.d_{6}\right) \delta: 9.45(\mathrm{t}, J=2.2 \mathrm{~Hz}$, $1 \mathrm{H}), 6.84(\mathrm{~s}, 1 \mathrm{H}), 6.58(\mathrm{~s}, 1 \mathrm{H}), 2.80(\mathrm{~d}, J=2.7 \mathrm{~Hz}, 2 \mathrm{H}), 2.57(\mathrm{t}, J=6.6 \mathrm{~Hz}, 2 \mathrm{H}), 2.49(\mathrm{~s}, 3 \mathrm{H})$, $2.18(\mathrm{~m}, 5 \mathrm{H}), 1.62(\mathrm{qt}, J=7.2 \mathrm{~Hz}, 2 \mathrm{H}), 1.50$ (qt, $J=7.5 \mathrm{~Hz}, 2 \mathrm{H}), 1.47$ (s, 6H), 1.39 (s, 9H), 1.33 $(\mathrm{m}, 4 \mathrm{H}) .{ }^{13} \mathrm{C}$ NMR $\left(125 \mathrm{MHz}, \mathrm{DMSO}-d_{6}\right) \delta: 203.06,172.72,172.69,149.66,137.97,136.42$, $133.40,132.34,123.64,79.86,56.36,38.09,35.11,34.46,31.53,28.51,28.47,28.20,25.32,24.86$, $24.35,20.14$.

3-[2-(O-acyloyl)hydroxyl-4,6-dimethyl]phenyl-3-methylbutanoic acid (12a-c)-General Procedure, To a stirred, ice-cold mixture of $2.48 \mathrm{mmol}$ of aldehyde, $100 \mu \mathrm{L}$ of $50 \% \mathrm{H}_{2} \mathrm{O}_{2}$ and $80 \mathrm{mg}$ of $\mathrm{NaH}_{2} \mathrm{PO}_{4}$ in $3 \mathrm{~mL}$ of $\mathrm{MeCN} / \mathrm{H}_{2} \mathrm{O}, 3 / 1, v / v, 450 \mathrm{mg}$ of $\mathrm{NaClO}_{2}$ in $2 \mathrm{~mL}$ of water was added dropwise. The reaction mixture was stirred at $0{ }^{\circ} \mathrm{C}$ for $1 \mathrm{~h}$ and then warmed to room temperature. The excess of oxidizing reagents was decomposed by a dropwise addition of saturated aqueous solution $\mathrm{Na}_{2} \mathrm{~S}_{2} \mathrm{O}_{3}$. Subsequently, the mixture was acidified with $3 \mathrm{M} \mathrm{HCl}$ to $\mathrm{pH} 2$ and extracted with AcOEt $(3 \times 30 \mathrm{~mL})$. The organic layer was washed with water $(30 \mathrm{~mL})$, brine $(2 \times 30 \mathrm{~mL})$, and water $(30 \mathrm{~mL})$, respectively. The organic layer was dried over anhydrous $\mathrm{MgSO}_{4}$, the desiccant was filtered off, and the filtrate was concentrated under reduced pressure. The product was purified by liquid column chromatography using a mixture of solvents hexanes/AcOEt/AcOH.

3-\{2-[O-(4-tert-butoxysuccinoyl)]hydroxyl-4,6-dimethyl\}phenyl-3-methylbutanoic acid 12a, Starting from $1.46 \mathrm{~g}$ (3.68 mmol) of aldehyde 11a, $1.09 \mathrm{~g}(2.88 \mathrm{mmol}, 78 \%)$ of carboxylic acid 12a was obtained as a light-yellow oil. $\mathrm{R}_{\mathrm{f}} 0.46$ (hexanes/AcOEt/AcOH, 70/30/1, $v / v / v)$. HRMS-ESI: $m / z$ calcd. For $\mathrm{C}_{21} \mathrm{H}_{30} \mathrm{O}_{6}$ 378.2042; found $379.2370[\mathrm{M}+1]^{+}$. ${ }^{1} \mathrm{H}$ NMR $\left(500 \mathrm{MHz}, \mathrm{DMSO}-d_{6}\right) \delta: 11.79(\mathrm{~s}, 1 \mathrm{H}), 6.80(\mathrm{~s}, 1 \mathrm{H}), 6.55(\mathrm{~s}, 1 \mathrm{H}), 2.78(\mathrm{t}, J=6.7 \mathrm{~Hz}, 2 \mathrm{H}), 2.71$ $(\mathrm{s}, 2 \mathrm{H}), 2.58(\mathrm{t}, J=6 \mathrm{~Hz}, 2 \mathrm{H}), 2.47(\mathrm{~s}, 3 \mathrm{H}), 2.17(\mathrm{~s}, 3 \mathrm{H}), 1.48(\mathrm{~s}, 6 \mathrm{H}), 1.41(\mathrm{~s}, 9 \mathrm{H}) .{ }^{13} \mathrm{C} \mathrm{NMR}$ $\left(125 \mathrm{MHz}, \mathrm{DMSO}-d_{6}\right) \delta: 173.10,171.82,171.56,149.74,138.00,135.70,134.25,132.00,123.17$, $80.51,48.14,38.45,31.26,30.21,28.36,25.26,20.12$.

3-\{2-[O-(4-tert-butoxypimeoyl)]hydroxyl-4,6-dimethyl\}phenyl-3-methylbutanoic acid 12b, Starting from $1.35 \mathrm{~g}$ (3.34 mmol) of aldehyde 11b, $740 \mathrm{mg}(1.76 \mathrm{mmol}, 53 \%)$ of carboxylic acid $\mathbf{1 2 b}$ was obtained as a colorless oil. $\mathrm{R}_{\mathrm{f}} 0.40$ (hexanes/AcOEt/AcOH, 80/20/1, v/v/v). HRMS-ESI: $m$ / $z$ calcd. for $\mathrm{C}_{24} \mathrm{H}_{36} \mathrm{O}_{6} 420.2512$; found $421.2515[\mathrm{M}+1]^{+}$. ${ }^{1} \mathrm{H} \mathrm{NMR}(500 \mathrm{MHz}$, DMSO-d $\left.d_{6}\right) \delta: 11.83($ brs, $1 \mathrm{H}), 6.81(\mathrm{~s}, 1 \mathrm{H}), 6.57(\mathrm{~s}, 1 \mathrm{H}), 2.70(\mathrm{~s}, 2 \mathrm{H}), 2.56(\mathrm{t}, J=7.5 \mathrm{~Hz}, 2 \mathrm{H})$, $2.50(\mathrm{~s}, 3 \mathrm{H}), 2.21(\mathrm{t}, J=7 \mathrm{~Hz}, 2 \mathrm{H}), 2.17(\mathrm{~s}, 3 \mathrm{H}), 1.64(\mathrm{qt}, J=7.4 \mathrm{~Hz}, 2 \mathrm{H}), 1.54(\mathrm{qt}, J=7.7 \mathrm{~Hz}$, $2 \mathrm{H}), 1.47(\mathrm{~s}, 6 \mathrm{H}), 1.43-1.30(\mathrm{~m}, 11 \mathrm{H}) .{ }^{13} \mathrm{C}$ NMR $\left(125 \mathrm{MHz}, \mathrm{DMSO}-d_{6}\right) \delta: 179.37,171.69$, $167.95,149.83,138.21,135.71,134.46,132.17,123.43,79.85,79.63,47.85,38.69,35.07,34.49$, $31.48,28.31,28.24,25.28,24.76,24.29,20.13$.

3-\{2-[O-(4-tert-butoxysuberoyl)]hydroxyl-4,6-dimethyl\}phenyl-3-methylbutanoic acid 12c, Starting from $2.92 \mathrm{~g}$ (6.98 mmol) of aldehyde 11c, $2.41 \mathrm{~g}(5.55 \mathrm{mmol}, 80 \%)$ of carboxylic acid 12c was obtained as a colorless oil. HRMS-ESI: $m / z$ calcd. for $\mathrm{C}_{25} \mathrm{H}_{38} \mathrm{O}_{6} 434.2668$; found 
435.2672 [M + 1] ${ }^{+} .{ }^{1} \mathrm{H}$ NMR (500 MHz, DMSO-d 6 ) $\delta: 11.81(\mathrm{~s}, 1 \mathrm{H}), 6.79(\mathrm{~s}, 1 \mathrm{H}), 6.56(\mathrm{~s}, 1 \mathrm{H})$, $2.70(\mathrm{~s}, 2 \mathrm{H}), 2.55(\mathrm{t}, J=7.2 \mathrm{~Hz}, 2 \mathrm{H}), 2.49(\mathrm{~s}, 3 \mathrm{H}), 2.19(\mathrm{t}, J=7.3 \mathrm{~Hz}, 2 \mathrm{H}), 2.17(\mathrm{~s}, 3 \mathrm{H}), 1.63$ (qt, $J=7.4 \mathrm{~Hz}, 2 \mathrm{H}), 1.50(\mathrm{qt}, J=7.7 \mathrm{~Hz}, 2 \mathrm{H}), 1.46(\mathrm{~s}, 6 \mathrm{H}), 1.39(\mathrm{~s}, 9 \mathrm{H}), 1.32(\mathrm{~m}, 4 \mathrm{H}) .{ }^{13} \mathrm{C} \mathrm{NMR}$ $\left(125 \mathrm{MHz}, \mathrm{DMSO}-d_{6}\right) \delta: 173.01,172.73,172.49,149.86,138.10,135.64,134.38,132.09,123.36$, $79.83,47.78,38.68,35.12,34.50,31.47,28.54,28.49,28.24,25.29,24.87,24.40,20.15$.

Benzyl 3-\{2-[O-(4-tertbutoxyacyloyl)]hydroxyl-4,6-dimethyl\}phenyl-3-methylbutanoate (13a-c)General Procedure, To a mixture of $2.64 \mathrm{mmol}$ of carboxylic acid dissolved in $20 \mathrm{~mL}$ of dry DMF, $5.28 \mathrm{mmol}$ of potassium bicarbonate was added, and the resulting suspension was allowed to stir at room temperature for $15 \mathrm{~min}$. Subsequently, $4 \mathrm{mmol}$ of benzyl bromide was added in one portion, and then, the reaction mixture was allowed to stir at $40{ }^{\circ} \mathrm{C}$ for $3 \mathrm{~h}$. The mixture was cooled to room temperature, and $30 \mathrm{~mL}$ of $5 \%$ solution of $\mathrm{NaHCO}_{3(\mathrm{aq})}$ was added. The resulting mixture was extracted with ethyl acetate $(3 \times 50 \mathrm{~mL})$, and then, the organic layer was washed with $5 \%$ solution of $\mathrm{NaHCO}_{3(\mathrm{aq})}(2 \times 50 \mathrm{~mL})$ and brine $(2 \times 50 \mathrm{~mL})$, respectively. The organic layer was dried over anhydrous $\mathrm{MgSO}_{4}$, the desiccant was filtered off, and the filtrate was concentrated under reduced pressure. The residue was purified by liquid column chromatography using a mixture of solvents hexanes / AcOEt, 8/2,v/v as a mobile phase.

Benzyl 3-\{2-[O-(4-tertbutoxysuccinoyl)]hydroxyl-4,6-dimethyl\}phenyl-3-methylbutanoate 13a, Starting from $1 \mathrm{~g}$ ( $2.64 \mathrm{mmol})$ of carboxylic acid 12a, $1 \mathrm{~g}(2.13 \mathrm{mmol}, 81 \%)$ of ester 13a was obtained as a light-yellow oil. $\mathrm{R}_{\mathrm{f}} 0.37$ (hexanes/AcOEt, 9/1, $v / v$ ). HRMS-ESI: $m / z$ calcd. for $\mathrm{C}_{28} \mathrm{H}_{36} \mathrm{O}_{6} 468.2512$; found $469.2840[\mathrm{M}+1]^{+} .{ }^{1} \mathrm{H} \mathrm{NMR}\left(500 \mathrm{MHz}, \mathrm{CDCl}_{3}\right) \delta: 7.13$ $(\mathrm{m}, 3 \mathrm{H}), 7.23(\mathrm{~m}, 2 \mathrm{H}), 6.80(\mathrm{~s}, 1 \mathrm{H}), 6.62(\mathrm{~s}, 1 \mathrm{H}), 5.02(\mathrm{~s}, 2 \mathrm{H}), 2.93(\mathrm{~s}, 2 \mathrm{H}), 2.81(\mathrm{t}, J=6.6 \mathrm{~Hz}$, 2H), $2.64(\mathrm{t}, J=7 \mathrm{~Hz}, 2 \mathrm{H}), 2.52(\mathrm{~s}, 3 \mathrm{H}), 2.25(\mathrm{~s}, 3 \mathrm{H}), 1.59(\mathrm{~s}, 6 \mathrm{H}), 1.49(\mathrm{~s}, 9 \mathrm{H}) .{ }^{13} \mathrm{C} \mathrm{NMR}$ $\left(125 \mathrm{MHz}_{1} \mathrm{CDCl}_{3}\right) \delta: 171.61,171.55,171.31,149.50,139.97,136.16,136.02,133.38,132.41$, $128.39,128.24,127.98,123.00,80.71,65.92,48.04,38.96,31.40,30.15,27.92,25.42,20.29$.

Benzyl 3-\{2-[O-(4-tertbutoxypimeoyl)]hydroxyl-4,6-dimethyl\}phenyl-3-methylbutanoate 13b, Starting from $750 \mathrm{mg}$ (1.78 mmol) of carboxylic acid 12b, $680 \mathrm{mg}(1.33 \mathrm{mmol}, 75 \%)$ of ester 13b was obtained as a colorless oil. $\mathrm{R}_{\mathrm{f}} 0.44$ (hexanes / AcOEt, 9/1, $v / v$ ). HRMS-ESI: $m / z$ calcd. for $\mathrm{C}_{31} \mathrm{H}_{42} \mathrm{O}_{6}$ 510.2981; found $511.2983[\mathrm{M}+1]^{+} .{ }^{1} \mathrm{H} \mathrm{NMR}\left(500 \mathrm{MHz}, \mathrm{CDCl}_{3}\right) \delta: 7.32$ $(\mathrm{m}, 3 \mathrm{H}), 7.21(\mathrm{~m}, 2 \mathrm{H}), 6.80(\mathrm{~s}, 1 \mathrm{H}), 6.58(\mathrm{~s}, 1 \mathrm{H}), 5.02(\mathrm{~s}, 2 \mathrm{H}), 2.53(\mathrm{~m}, 5 \mathrm{H}), 2.26(\mathrm{~m}, 5 \mathrm{H}), 1.76$ $(\mathrm{qt}, J=7.6 \mathrm{~Hz}, 2 \mathrm{H}), 1.35(\mathrm{qt}, J=7.7 \mathrm{~Hz}, 2 \mathrm{H}), 1.58(\mathrm{~s}, 6 \mathrm{H}), 1.53-1.39(\mathrm{~m}, 11 \mathrm{H}) .{ }^{13} \mathrm{C} \mathrm{NMR}$ $\left(125 \mathrm{MHz}, \mathrm{CDCl}_{3}\right) \delta: 172.99,172.44,171.56,149.47,138.00,136.13,136.01,133.38,132.36$, $128.36,128.24,127.97,123.04,80.06,66.06,47.90,39.05,35.30,34.88,31.57,28.60,28.18,25.28$, $24.86,24.39,20.22$.

Benzyl 3-\{2-[O-(4-tertbutoxysuberoyl)]hydroxyl-4,6-dimethyl\}phenyl-3-methylbutanoate 13c, Starting from $750 \mathrm{mg}(1.78 \mathrm{mmol})$ of carboxylic acid 12c, $680 \mathrm{mg}(1.33 \mathrm{mmol}, 75 \%)$ of ester 13c was obtained as a colorless oil. $\mathrm{R}_{\mathrm{f}} 0.44$ (hexanes/AcOEt, 9/1, $v / v$ ). HRMS-ESI: $m / z$ calcd. for $\mathrm{C}_{32} \mathrm{H}_{44} \mathrm{O}_{6}$ 524.3138; found $525.3134[\mathrm{M}+1]^{+} .{ }^{1} \mathrm{H}$ NMR (500 MHz, $\left.\mathrm{CDCl}_{3}\right) \delta: 7.32$ $(\mathrm{m}, 3 \mathrm{H}), 7.21(\mathrm{~m}, 2 \mathrm{H}), 6.80(\mathrm{~s}, 1 \mathrm{H}), 6.57(\mathrm{~s}, 1 \mathrm{H}), 5.01(\mathrm{~s}, 2 \mathrm{H}), 2.89(\mathrm{~s}, 2 \mathrm{H}), 2.51(\mathrm{~m}, 5 \mathrm{H}), 2.25$ $(\mathrm{s}, 3 \mathrm{H}), 2.23(\mathrm{t}, J=7.6 \mathrm{~Hz}, 2 \mathrm{H}), 1.73(\mathrm{qt}, J=7.4 \mathrm{~Hz}, 2 \mathrm{H}), 1.61(\mathrm{qt}, J=7.5 \mathrm{~Hz}, 2 \mathrm{H}), 1.57$ (s, $6 \mathrm{H}), 1.47$ (s, 9H), $1.38(\mathrm{~m}, 4 \mathrm{H}) .{ }^{13} \mathrm{C} \mathrm{NMR}\left(125 \mathrm{MHz}, \mathrm{CDCl}_{3}\right) \delta: 173.18,172.60,171.60,159.39$, 149.50, 138.01, 136.14, 136.01, 133.33, 132.37, 128.37, 128.22, 127.99, 123.03, 80.01, 66.02, 47.78, $38.96,35.49,34.95,31.52,28.86,28.76,28.14,25.33,24.90,24.51,20.28$.

Benzyl 3-[2-[O-acyloyl]hydroxyl-4,6-dimethyl]phenyl-3-methylbutanoate (14a-c)_General Procedure, First, $2.13 \mathrm{mmol}$ of tert-butyl ester was dissolved in $20 \mathrm{~mL}$ of a mixture of DCM/TFA, 3/1, $v / v$ and allowed to stir at room temperature for $1 \mathrm{~h}$. The solvents were removed under reduced pressure, and the residue was purified by liquid column chromatography, using a mixture of solvents hexanes/AcOEt/AcOH, 70/30/1, v/v/v as a mobile phase.

Benzyl 3-[2-[O-succinoyl]hydroxyl-4,6-dimethyl]phenyl-3-methylbutanoate 14a, Starting from $1 \mathrm{~g}$ ( $2.13 \mathrm{mmol})$ of ester 13a, $820 \mathrm{mg}$ ( $2 \mathrm{mmol}, 94 \%)$ of carboxylic acid 14a was obtained as a light-yellow oil. HRMS-ESI: $m / z$ calcd. for $\mathrm{C}_{24} \mathrm{H}_{28} \mathrm{O}_{6} 412.1892$; found $413.1950[\mathrm{M}+1]^{+}$. ${ }^{1} \mathrm{H}$ NMR (500 MHz, DMSO-d 6 ) $\delta: 12.34$ (brs, 1H), $7.31(\mathrm{~m}, 3 \mathrm{H}), 7.18(\mathrm{~m}, 2 \mathrm{H}), 6.79(\mathrm{~s}, 1 \mathrm{H})$, $6.57(\mathrm{~s}, 1 \mathrm{H}), 4.95(\mathrm{~s}, 2 \mathrm{H}), 2.90(\mathrm{~s}, 2 \mathrm{H}), 2.74(\mathrm{t}, J=6 \mathrm{~Hz}, 2 \mathrm{H}), 2.56(\mathrm{t}, J=6.9 \mathrm{~Hz}, 2 \mathrm{H}), 2.47$ 
$(\mathrm{s}, 3 \mathrm{H}), 2.18(\mathrm{~s}, 3 \mathrm{H}), 1.47(\mathrm{~s}, 6 \mathrm{H}) .{ }^{13} \mathrm{C}$ NMR $\left(125 \mathrm{MHz}, \mathrm{DMSO}-d_{6}\right) \delta: 173.90,172.07,171.42$, $150.10,138.06,136.81,135.77,134.13$, 132.30, 128.71, 128.25 123.30, 65.52, 47.73, 38.83, 31.37, $30.33,28.89,25.36,20.19$.

Benzyl 3-[2-[O-pimeoyl]hydroxyl-4,6-dimethyl]phenyl-3-methylbutanoate 14b, Starting from $680 \mathrm{mg}$ (1.33 mmol) of ester 13b, $490 \mathrm{mg}$ (1.08 mmol, 81\%) of carboxylic acid 14b was obtained as a colorless oil. $\mathrm{R}_{\mathrm{f}} 0.42$ (hexanes/AcOEt/AcOH, 70/30/1, $/ v / v$ ). HRMS-ESI: $m / z$ calcd. for $\mathrm{C}_{27} \mathrm{H}_{34} \mathrm{O}_{6} 454.2355$; found $455.2361[\mathrm{M}+1]^{+} .{ }^{1} \mathrm{H}$ NMR $\left(500 \mathrm{MHz}, \mathrm{DMSO}-d_{6}\right)$ $\delta: 12.03$ (brs, 1H), $7.31(\mathrm{~m}, 3 \mathrm{H}), 7.18(\mathrm{~m}, 2 \mathrm{H}), 6.80(\mathrm{~s}, 1 \mathrm{H}), 6.58(\mathrm{~s}, 1 \mathrm{H}), 4.95(\mathrm{~s}, 2 \mathrm{H}), 2.86(\mathrm{~s}$, 2H), $2.52(\mathrm{~m}, 2 \mathrm{H}), 2.46(\mathrm{~s}, 3 \mathrm{H}), 2.21(\mathrm{t}, J=7.5 \mathrm{~Hz}, 2 \mathrm{H}), 2.19(\mathrm{~s}, 3 \mathrm{H}), 1.60(\mathrm{qt}, J=7.8 \mathrm{~Hz}, 2 \mathrm{H})$, $1.52-1.41(\mathrm{~m}, 8 \mathrm{H}), 1.33(\mathrm{~m}, 2 \mathrm{H}) .{ }^{13} \mathrm{C}$ NMR $\left(125 \mathrm{MHz}, \mathrm{DMSO}-d_{6}\right) \delta: 174.92,172.48,171.26$, $149.83,138.02,136.46,135.85,133.85,132.18,128.73,128.35,123.53,65.68,47.70,39.05,34.40$, $33.97,31.48,28.44,25.33,24.63,24.26,20.17$.

Benzyl 3-[2-[O-suberoyl]hydroxyl-4,6-dimethyl]phenyl-3-methylbutanoate 14c, Starting from $2.36 \mathrm{~g}(4.50 \mathrm{mmol})$ of ester $13 \mathrm{c}, 1.97 \mathrm{~g}(4.20 \mathrm{mmol}, 93 \%)$ of carboxylic acid $14 \mathrm{c}$ was obtained as a colorless oil. $\mathrm{R}_{\mathrm{f}} 0.48$ (hexanes/AcOEt/AcOH, 70/30/1, $v / v / v$ ). HRMS-ESI: $m / z$ calcd. for $\mathrm{C}_{28} \mathrm{H}_{36} \mathrm{O}_{6}$ 468.2512; found 469.2516 [M + 1] ${ }^{+} .{ }^{1} \mathrm{H}$ NMR (500 MHz, DMSO- $\left.d_{6}\right) \delta$ : 11.97 (brs, 1H), $7.30(\mathrm{~m}, 3 \mathrm{H}), 7.18(\mathrm{~m}, 2 \mathrm{H}), 6.78(\mathrm{~s}, 1 \mathrm{H}), 6.57(\mathrm{~s}, 1 \mathrm{H}), 4.94(\mathrm{~s}, 2 \mathrm{H}), 2.84(\mathrm{~s}, 2 \mathrm{H}), 2.50$ $(\mathrm{m}, 2 \mathrm{H}), 2.45(\mathrm{~s}, 3 \mathrm{H}), 2.18(\mathrm{~m}, 5 \mathrm{H}), 1.58(\mathrm{qt}, J=6.4 \mathrm{~Hz}, 2 \mathrm{H}), 1.47(\mathrm{~m}, 8 \mathrm{H}), 1.29(\mathrm{~m}, 4 \mathrm{H}) .{ }^{13} \mathrm{C}$ NMR $\left(125 \mathrm{MHz}, \mathrm{DMSO}-d_{6}\right) \delta: 174.91,172.50,171.27,149.78,138.05,136.47,135.88,133.75$, $132.14,128.68,128.29,123.50,65.59,47.58,38.98,34.48,34.02,31.47,28.62,28.58,25.31,24.76$, $24.39,20.18$.

$N^{1}, N^{7}$-bis(tert-butoxycarbonyl)spermidine 16, First, $1.23 \mathrm{~g}(8.47 \mathrm{mmol})$ of spermidine 15 was dissolved in $50 \mathrm{~mL}$ of dry THF and cooled in an ice bath to $0{ }^{\circ} \mathrm{C}$. Then, $4.17 \mathrm{~g}$ (16.94 mmol) of Boc-ON, dissolved in $50 \mathrm{~mL}$ of dry THF, was added dropwise. The mixture was allowed to stir at $0{ }^{\circ} \mathrm{C}$ for $4 \mathrm{~h}$, and then, solvents were evaporated under reduced pressure. The residue was dissolved in $50 \mathrm{~mL}$ of $\mathrm{Et}_{2} \mathrm{O}$ and washed with saturated $\mathrm{NaOH}_{(\mathrm{aq})}$ until the yellow color disappeared. The organic layer was dried over anhydrous $\mathrm{MgSO}_{4}$, the desiccant was filtered off, and the filtrate was concentrated under reduced pressure. The white crystalline residue was recrystallized from $\mathrm{Et}_{2} \mathrm{O}$ obtaining $1.88 \mathrm{~g}$ (5.44 mmol, $64 \%$ ) of product 16 as white solid, with m.p. $83-85^{\circ} \mathrm{C} .{ }^{1} \mathrm{H}$ NMR $\left(500 \mathrm{MHz}, \mathrm{CDCl}_{3}\right) \delta: 5.22$ (brs, 1H), 4.88 (brs, 1H), $3.21(\mathrm{~m}, 2 \mathrm{H}), 3.14(\mathrm{~m}, 2 \mathrm{H}), 2.67(\mathrm{t}, J=6.6 \mathrm{~Hz}, 2 \mathrm{H}), 2.61(\mathrm{t}, J=6.2 \mathrm{~Hz}$, $2 \mathrm{H}), 1.65(\mathrm{qt}, J=6.5 \mathrm{~Hz}, 2 \mathrm{H}), 1.53(\mathrm{~m}, 4 \mathrm{H}), 1.45(\mathrm{~s}, 18 \mathrm{H}) .{ }^{13} \mathrm{C} \mathrm{NMR}\left(125 \mathrm{MHz}, \mathrm{CDCl}_{3}\right) \delta$ : $156.09,156.01,78.94,49.45,47.75,40.53,39.29,29.88,28.44,27.84,27.41$.

Boc $_{2}$-spermidine-'trimethyl lock' benzyl ester building block $(\mathbf{1 8 a}-\mathbf{c})$-General Procedure, To the solution of $2.42 \mathrm{mmol}$ of carboxylic acid $\mathbf{1 4 a}-\mathbf{c}$ and $3.06 \mathrm{mmol}$ of NHS in $20 \mathrm{~mL}$ of dry DCM, $4.34 \mathrm{mmol}$ of DCC dissolved in $5 \mathrm{~mL}$ of dry DCM was added dropwise, and then, the mixture was allowed to stir at room temperature for $24 \mathrm{~h}$. The precipitate of DCU was filtered off under reduced pressure, and the filtrate was diluted with $50 \mathrm{~mL}$ of DCM. Subsequently, the mixture was washed with water $(2 \times 30 \mathrm{~mL})$, saturated solution of $\mathrm{NaHCO}_{3(\mathrm{aq})}(2 \times 30 \mathrm{~mL})$, and water $(2 \times 30 \mathrm{~mL})$, respectively. The organic layer was dried over anhydrous $\mathrm{MgSO}_{4}$, the desiccant was filtered off, and the filtrate was concentrated under reduced pressure. The residue was dissolved in $50 \mathrm{~mL}$ of dry DCM, and $6.72 \mathrm{mmol}$ of DIPEA and $3.2 \mathrm{mmol}$ of $\mathrm{Boc}_{2}$-spermidine 16 were added. The mixture was allowed to stir at room temperature for $5 \mathrm{~h}$; then, $20 \mathrm{~mL}$ of DCM was added, and the resulting solution was washed with brine $(2 \times 30 \mathrm{~mL}), 5 \%$ solution of $\mathrm{NaHSO}_{4(\mathrm{aq})}(2 \times 30 \mathrm{~mL})$, and brine $(2 \times 30 \mathrm{~mL})$, respectively. The organic layer was dried over anhydrous $\mathrm{MgSO}_{4}$, the desiccant was filtered off, and the filtrate was concentrated under reduced pressure. The residue was purified by liquid column chromatography, using a mixture of solvents hexanes/AcOEt, 4/6, $v / v$ as a mobile phase.

$N^{1}, N^{7}$-bis(tert-butoxycarbonyl)-N $N^{3}-\{4$-[2-(2-benzyloxycarbonyl-1,1-dimethylethyl)-3,5-dimethyl] phenoxy-1,4-dioxo b butylspermidine 18a, Starting from $1 \mathrm{~g}(2.42 \mathrm{mmol})$ of carboxylic acid 14a and $1.1 \mathrm{~g}$ (3.2 mmol) of Boc $_{2}$-spermidine 16, $1.1 \mathrm{~g}(1.4 \mathrm{mmol}, 68 \%)$ of product 18a was obtained as a colorless oil with $\mathrm{R}_{\mathrm{f}} 0.50$ (hexanes/AcOEt, 4/6, $v / v$ ). HRMS-ESI: $\mathrm{m} / \mathrm{z}$ calcd. for $\mathrm{C}_{41} \mathrm{H}_{61} \mathrm{~N}_{3} \mathrm{O}_{9}$ 739.4408; found $740.4537[\mathrm{M}+1]^{+} .{ }^{1} \mathrm{H} \mathrm{NMR}\left(500 \mathrm{MHz}, \mathrm{CD}_{3} \mathrm{OD}\right) \delta: 7.29$ 
$(\mathrm{m}, 3 \mathrm{H}), 7.16(\mathrm{~m}, 2 \mathrm{H}), 6.79(\mathrm{~s}, 1 \mathrm{H}), 6.63(\mathrm{~m}, 1 \mathrm{H}), 4.95(\mathrm{~s}, 2 \mathrm{H}), 3.36(\mathrm{~m}, 4 \mathrm{H}), 3.12-2.97(\mathrm{~m}, 4 \mathrm{H})$, $2.93(\mathrm{~s}, 2 \mathrm{H}), 2.83(\mathrm{~m}, 2 \mathrm{H}), 2.75(\mathrm{~m}, 2 \mathrm{H}), 2.49(\mathrm{~s}, 3 \mathrm{H}), 2.22(\mathrm{~s}, 3 \mathrm{H}), 1.92-1.36(\mathrm{~m}, 30 \mathrm{H}) .{ }^{13} \mathrm{C}$ NMR $\left(125 \mathrm{MHz}, \mathrm{CD}_{3} \mathrm{OD}\right) \delta:$ 172.47, 172.42, 172.13, 171.88, 171.72, 157.11, 156.95, 149.70, $137.80,136.08,135.83,133.14,131.74,127.97,127.82,127.57,122.73,78.09,65.49,45.49,45.23$, $43.08,39.60,39.35,38.77,37.39,37.19,33.40,30.87,29.91,28.72,27.38,26.87,25.48,25.36$, 24.66, 24.55, 24.16, 18.95 .

$N^{1}, N^{7}$-bis(tert-butoxycarbonyl)-N $N^{3}$-\{4-[2-(2-benzyloxycarbonyl-1,1-dimethylethyl)-3,5-dimethyl] phenoxy-1,7-dioxo 3 heptylspermidine $\mathbf{1 8 b}$, Starting from $490 \mathrm{mg}(1.08 \mathrm{mmol})$ of carboxylic acid $14 \mathrm{~b}$ and $374 \mathrm{mg}(1.08 \mathrm{mmol})$ of $\mathrm{Boc}_{2}$-spermidine $16,370 \mathrm{mg}(0.47 \mathrm{mmol}, 44 \%)$ of product $18 \mathrm{~b}$ was obtained as a colorless oil with $\mathrm{R}_{\mathrm{f}} 0.47$ (hexanes / AcOEt, 4/6, $v / v$ ). HRMS-ESI: $m / z$ calcd. for $\mathrm{C}_{44} \mathrm{H}_{67} \mathrm{~N}_{3} \mathrm{O}_{9} 781.4877$; found $782.4851[\mathrm{M}+1]^{+} .{ }^{1} \mathrm{H}$ NMR $\left(500 \mathrm{MHz}, \mathrm{CDCl}_{3}\right)$ $\delta: 7.30(\mathrm{~m}, 3 \mathrm{H}), 7.19(\mathrm{~m}, 2 \mathrm{H}), 6.78(\mathrm{~s}, 1 \mathrm{H}), 6.57(\mathrm{~s}, 1 \mathrm{H}), 5.00(\mathrm{~s}, 2 \mathrm{H}), 3.46-3.02(\mathrm{~m}, 8 \mathrm{H}), 2.89(\mathrm{~s}$, 2H), $2.54(\mathrm{t}, J=7.2 \mathrm{~Hz}, 2 \mathrm{H}), 2.51(\mathrm{~s}, 3 \mathrm{H}), 2.33(\mathrm{t}, J=7.6 \mathrm{~Hz}, 2 \mathrm{H}), 2.24(\mathrm{~s}, 3 \mathrm{H}), 1.83-1.38(\mathrm{~m}$, 36H). ${ }^{13} \mathrm{C} \mathrm{NMR}\left(125 \mathrm{MHz} \mathrm{CDCl}_{3}\right) \delta: 173.14,172.53,172.32,171.62,156.08,149.51,138.02$, $136.11,136.01,133.36,132.33,128.36,128.21,127.97,123.05,79.34,78.77,77.25,65.98,47.83$, $47.40,45.51,42.38,39.94,39.06,37.30,34.86,33.98,32.83,31.54,29.92,28.95,28.50,28.43$, $27.97,27.66,26.15,25.30,25.11,24.96,24.48,20.28,14.21$.

$N^{1}, N^{7}$-bis(tert-butoxycarbonyl)-N $N^{3}$-\{4-[2-(2-benzyloxycarbonyl-1,1-dimethylethyl)-3,5-dimethyl] phenoxy-1,8-dioxoloctylspermidine 18c, Starting from $1.97 \mathrm{~g}(4.20 \mathrm{mmol})$ of carboxylic acid 14c and $1.55 \mathrm{~g}(4.50 \mathrm{mmol})$ of Boc $_{2}$-spermidine 16, $2.03 \mathrm{~g}(2.55 \mathrm{mmol}, 61 \%)$ of product 18c was obtained as a colorless oil with $\mathrm{R}_{\mathrm{f}} 0.45$ (hexanes / AcOEt, 4/6, $v / v$ ). HRMS-ESI: $m / z$ calcd. for $\mathrm{C}_{45} \mathrm{H}_{69} \mathrm{~N}_{3} \mathrm{O}_{9}$ 795.5034; found $796.5126[\mathrm{M}+1]^{+} .{ }^{1} \mathrm{H} \mathrm{NMR}\left(500 \mathrm{MHz}, \mathrm{CDCl}_{3}\right) \delta$ : $7.30(\mathrm{~m}, 3 \mathrm{H}), 7.18(\mathrm{~m}, 2 \mathrm{H}), 6.78(\mathrm{~s}, 1 \mathrm{H}), 6.55(\mathrm{~s}, 1 \mathrm{H}), 5.43(\mathrm{~m}, 1 \mathrm{H}), 4.99(\mathrm{~s}, 2 \mathrm{H}), 4.69(\mathrm{~m}, 1 \mathrm{H})$, 3.44-3.01 (m, 8H), $2.88(\mathrm{~s}, 2 \mathrm{H}), 2.50(\mathrm{~m}, 5 \mathrm{H}), 2.30(\mathrm{~m}, 2 \mathrm{H}), 2.24(\mathrm{~s}, 3 \mathrm{H}), 1.77-1.62(\mathrm{~m}, 6 \mathrm{H})$, 1.61-1.52 (m, 8H), 1.51-1.31 (m, 24H). $\left.{ }^{13} \mathrm{C} \mathrm{NMR} \mathrm{(125} \mathrm{MHz,} \mathrm{CDCl}_{3}\right) \delta: 167.89,166.80,166.45$, $151.25,144.79,133.27,131.37,131.23,128.59,127.58,123.61,123.45,123.24,118.30,74.13$, $61.07,55.66,42.98,42.66,40.65,37.51,35.07,34.31,32.36,30.17,28.16,26.72,24.43,23.68$, 22.91, 21.38, 20.55, 19.73, 16.31, 15.53 .

Boc $_{2}$-spermidine-'trimethyl lock' carboxylic acid building block (19a-c)_General Procedure, First, $1.64 \mathrm{mmol}$ of benzyl ester was dissolved in $30 \mathrm{~mL}$ of THF, and then, $500 \mathrm{mg}$ of 10\% $\mathrm{Pd} / \mathrm{C}$ was added. The mixture was allowed to stir at room temperature under hydrogen (balloon) atmosphere for $4 \mathrm{~h}$. Subsequently, the catalyst was filtered off under reduced pressure through a thin layer of celite. The filtrate was concentrated under reduced pressure, obtaining $1.41 \mathrm{mmol}$ of carboxylic acid 19.

$N^{1}, N^{7}$-bis(tert-butoxycarbonyl)-N $N^{3}-\{4$-[2-(2-carboxy-1,1-dimethylethyl)-3,5-dimethyl]phenoxy1,4-dioxo\}butylspermidine 19a, Starting from $1.21 \mathrm{~g}$ (1.64 mmol) of ester 18a, $918 \mathrm{mg}(1.41 \mathrm{mmol}$, $86 \%)$ of carboxylic acid 19a was obtained as a colorless oil, with $\mathrm{R}_{\mathrm{f}} 0.73\left(\mathrm{CHCl}_{3} / \mathrm{MeOH} / \mathrm{H}_{2} \mathrm{O}\right.$, 65/10/1, $v / v / v)$. HRMS-ESI: $m / z$ calcd. for $\mathrm{C}_{34} \mathrm{H}_{55} \mathrm{~N}_{3} \mathrm{O}_{9} 649.3938$; found 650.3858 [M + $1]^{+} .{ }^{1} \mathrm{H}$ NMR $\left(500 \mathrm{MHz}, \mathrm{CD}_{3} \mathrm{OD}\right) \delta: 6.82(\mathrm{~s}, 1 \mathrm{H}), 6.61(\mathrm{~m}, 1 \mathrm{H}), 3.38(\mathrm{~m}, 4 \mathrm{H}), 3.09(\mathrm{~m}, 2 \mathrm{H})$, $3.01(\mathrm{~m}, 2 \mathrm{H}), 2.87(\mathrm{~m}, 2 \mathrm{H}), 2.84(\mathrm{~s}, 2 \mathrm{H}), 2.80(\mathrm{~m}, 2 \mathrm{H}), 2.55(\mathrm{~s}, 3 \mathrm{H}), 2.20(\mathrm{~s}, 3 \mathrm{H}), 1.90-1.28(\mathrm{~m}$, 30H). ${ }^{13} \mathrm{C}$ NMR $\left(125 \mathrm{MHz}, \mathrm{CD}_{3} \mathrm{OD}\right) \delta: 174.05,172.56,172.51,172.20,171.80,149.62,137.85$, $135.69,133.66,131.66,122.66,78.12,47.35,45.39,45.17,43.07,39.55,39.36,38.39,37.38,37.23$, $33.34,30.64,29.95,27.56,27.40,26.84,25.49,25.33,24.68,24.55,24.18,18.91$.

$N^{1}, N^{7}$-bis(tert-butoxycarbonyl)-N $N^{3}-\{4$-[2-(2-carboxy-1,1-dimethylethyl)-3,5-dimethyl]phenoxy1,4-dioxolheptylspermidine 19b, Starting from $350 \mathrm{mg}(0.448 \mathrm{mmol})$ of ester 18b, $298 \mathrm{mg}$ ( $0.431 \mathrm{mmol}, 96 \%)$ of carboxylic acid $19 \mathrm{~b}$ was obtained as a light-yellow oil. HRMS-ESI: $m / z$ calcd. for $\mathrm{C}_{37} \mathrm{H}_{61} \mathrm{~N}_{3} \mathrm{O}_{9}$ 691.4408; found 692.4414 [M + 1] ${ }^{+} .{ }^{1} \mathrm{H}$ NMR (500 MHz, DMSO$\left.d_{6}\right) \delta: 11.70(\mathrm{brs}, 1 \mathrm{H}), 6.80(\mathrm{~s}, 1 \mathrm{H}), 6.58(\mathrm{~s}, 1 \mathrm{H}), 3.21(\mathrm{~m}, 4 \mathrm{H}), 2.91(\mathrm{~m}, 4 \mathrm{H}), 2.70(\mathrm{~s}, 2 \mathrm{H}), 2.56$ $(\mathrm{t}, J=7.1 \mathrm{~Hz}, 2 \mathrm{H}), 2.50(\mathrm{~s}, 3 \mathrm{H}), 2.27(\mathrm{~m}, 2 \mathrm{H}), 2.17(\mathrm{~s}, 3 \mathrm{H}), 1.78-1.20(\mathrm{~m}, 36 \mathrm{H}) .{ }^{13} \mathrm{C} \mathrm{NMR}$ $\left(125 \mathrm{MHz}, \mathrm{DMSO}-d_{6}\right) \delta: 173.04,172.51,172.04,171.83,156.20,149.87,138.09,135.74,134.31$, $132.16,123.41,107.65,79.74,67.18,47.87,38.67,34.52,33.80,32.38,31.47,29.36,28.74,28.30$, $27.58,27.25,26.34,25.29,25.18,24.89,24.56,24.09,22.20,20.17$.

$N^{1}, N^{7}$-bis(tert-butoxycarbonyl)-N $N^{3}-\{4$-[2-(2-carboxy-1,1-dimethylethyl)-3,5-dimethyl]phenoxy1,4-dioxoloctylspermidine 19c, Starting from $2.03 \mathrm{~g}$ (2.55 mmol) of ester 18c, $1.95 \mathrm{~g}$ (2.50 mmol, 
98\%) of carboxylic acid 19c was obtained as a light-yellow oil with $\mathrm{R}_{\mathrm{f}} 0.64\left(\mathrm{CHCl}_{3} / \mathrm{MeOH} / \mathrm{H}_{2} \mathrm{O}\right.$, 65/10/1, v/v/v). HRMS-ESI: $m / z$ calcd. for $\mathrm{C}_{38} \mathrm{H}_{63} \mathrm{~N}_{3} \mathrm{O}_{9} 705.4564$; found $706.4572[\mathrm{M}+1]^{+}$. ${ }^{1} \mathrm{H}$ NMR (500 MHz, DMSO- $\left.d_{6}\right) \delta: 11.84$ (brs, $\left.1 \mathrm{H}\right), 6.90-6.83(\mathrm{~m}, 1 \mathrm{H}), 6.78-6.73(\mathrm{~m}, 2 \mathrm{H}), 3.20$ $(\mathrm{m}, 4 \mathrm{H}), 2.90(\mathrm{~m}, 4 \mathrm{H}), 2.69(\mathrm{~s}, 2 \mathrm{H}), 2.56(\mathrm{t}, J=7.4 \mathrm{~Hz}, 2 \mathrm{H}), 2.49(\mathrm{~s}, 3 \mathrm{H}), 2.24(\mathrm{~m}, 2 \mathrm{H}), 2.17(\mathrm{~s}$, $3 \mathrm{H}), 1.62(\mathrm{~m}, 3 \mathrm{H}), 3.72(\mathrm{~m}, 10 \mathrm{H}), 3.45(\mathrm{~m}, 26 \mathrm{H}) .{ }^{13} \mathrm{C}$ NMR $\left(125 \mathrm{MHz}, \mathrm{DMSO}-d_{6}\right) \delta: 173.08$, $172.50,172.08,171.75,156.03,149.82,138.11,135.62,134.27,132.07,123.44,79.62,47.86,47.33$, $44.97,43.03,38.70,38.06,37.87,34.57,32.45,31.44,28.88,28.69,28.34,27.54,26.31,25.30$, $24.49,20.15$.

Trisodium $O, \mathrm{O}^{\prime}$-bis(sulfate)deoxycholate 21a, To the solution of $1 \mathrm{~g}(2.55 \mathrm{mmol})$ of deoxycholic acid 20a in $10 \mathrm{~mL}$ of dry DMF, $7.32 \mathrm{~g}(46 \mathrm{mmol})$ of $\mathrm{SO}_{3} /$ Py complex was added in one portion. The mixture was stirred at room temperature for $24 \mathrm{~h}$. Subsequently, the mixture was alkalinized to $\mathrm{pH} 8$ with a saturated solution of $\mathrm{NaHCO}_{3(\mathrm{aq})}$. The solvents were evaporated under reduced pressure, the residue was suspended in $100 \mathrm{~mL}$ of $\mathrm{MeOH}$, and then inorganic salts were filtered off. The filtrate was concentrated under reduced pressure, which was followed by treatment with $\mathrm{MeCN}$. The formed precipitate was filtered off, obtaining $1.55 \mathrm{~g}(2.50 \mathrm{mmol}, 98 \%)$ of product 21a as a light-beige solid with m.p. 202-204 ${ }^{\circ} \mathrm{C}$ and $\mathrm{R}_{\mathrm{f}} 0.39\left(\mathrm{CHCl}_{3} / \mathrm{MeOH} / \mathrm{H}_{2} \mathrm{O}, 7 / 4 / 1, v / v / v\right) .{ }^{1} \mathrm{H}$ NMR $\left(500 \mathrm{MHz}, \mathrm{CD}_{3} \mathrm{OD}\right)$ $\delta: 4.86(\mathrm{~s}, 1 \mathrm{H}), 4.26(\mathrm{~m}, 1 \mathrm{H}), 2.36-2.20(\mathrm{~m}, 2 \mathrm{H}), 2.08(\mathrm{~m}, 1 \mathrm{H}), 2.00-1.71(\mathrm{~m}, 10 \mathrm{H}), 1.69-1.54$ $(\mathrm{m}, 2 \mathrm{H}), 1.54-1.23(\mathrm{~m}, 8 \mathrm{H}), 1.23-0.90(\mathrm{~m}, 9 \mathrm{H}), 0.76(\mathrm{~s}, 3 \mathrm{H}) .{ }^{13} \mathrm{C} \mathrm{NMR}\left(125 \mathrm{MHz}, \mathrm{CD}_{3} \mathrm{OD}\right) \delta$ : $182.28,81.21,79.15,45.99,42.35,36.06,35.93,35.60,35.36,35.14,34.00,33.62,33.30,32.56$, $30.23,28.95,27.34,27.05,26.05,24.68,23.49,22.30,16.95,11.61$.

Tetrasodium $\mathrm{O}, \mathrm{O}^{\prime}, \mathrm{O}^{\prime \prime}$-tris(sulfate) cholate $\mathbf{2 1 \mathbf { b }}$, Compound $\mathbf{2 1 \mathbf { b }}$ was prepared in a similar manner as 21a. Starting from $1 \mathrm{~g}(2.45 \mathrm{mmol})$ of cholic acid $20 \mathrm{~b}$ and $10.5 \mathrm{~g}(66 \mathrm{mmol})$ of $\mathrm{SO}_{3} /$ Py complex, $1.49 \mathrm{~g}(2 \mathrm{mmol}, 82 \%)$ of product $21 \mathrm{~b}$ was obtained as a light-beige solid. ${ }^{1} \mathrm{H}$ NMR $\left(500 \mathrm{MHz}, \mathrm{CD}_{3} \mathrm{OD}\right) \delta: 4.68(\mathrm{~s}, 1 \mathrm{H}), 4.46(\mathrm{~m}, 1 \mathrm{H}), 4.15(\mathrm{~m}, 1 \mathrm{H}), 2.52-2.21(\mathrm{~m}, 5 \mathrm{H})$, 2.18-1.62 (m, 12H), 1.50-1.22 (m, 5H), 1.17-0.90 (m, 8H), 0.78 (s, 3H). ${ }^{13} \mathrm{C}$ NMR (125 MHz, $\left.\mathrm{CD}_{3} \mathrm{OD}\right) \delta: 182.48,81.06,79.52,76.71,45.90,42.19,42.05,39.34,36.19,35.69,35.39,35.10$, $34.14,32.49,30.30,29.10,27.59,27.44,27.27,24.55,22.52,21.82,17.01,11.61$.

Trisodium $O, O^{\prime}$-bis(sulfate)deoxycholate active ester 22a, To the solution of $1.5 \mathrm{~g}(2.42 \mathrm{mmol})$ of deoxycholic acid derivative 21a in $30 \mathrm{~mL}$ of dry DMF, $355 \mu \mathrm{L}$ (2.04 mmol) of DIPEA and $916 \mathrm{mg}$ ( $3.03 \mathrm{mmol}$ ) of DEPBT were added, respectively. The mixture was stirred at room temperature for $2 \mathrm{~h}$ and then concentrated under reduced pressure. The oily residue was treated with $\mathrm{MeCN}$ and the formed precipitate was filtered off, obtaining $1.35 \mathrm{~g}(1.57 \mathrm{mmol}$, $65 \%$ ) of crude active ester 22a as a light-yellow solid, which was used in the next step without further purification.

Tetrasodium $\mathrm{O}, \mathrm{O}^{\prime}, \mathrm{O}^{\prime \prime}$-tris(sulfate) cholate active ester $\mathbf{2 2} \mathbf{b}$, Active ester $\mathbf{2 2} \mathbf{b}$ was prepared in a similar manner as 22a. Starting from $1.50 \mathrm{~g}(2.04 \mathrm{mmol})$ of cholic acid derivative $\mathbf{2 1 b}$, $1.16 \mathrm{~g}(1.35 \mathrm{mmol}, 66 \%)$ of active ester $\mathbf{2 2} \mathbf{b}$ was obtained as a light-yellow solid, which was used in the next step without further purification.

Cholic acid active ester 22c, First, $15 \mathrm{~g}$ ( $37 \mathrm{mmol})$ of cholic acid was dissolved in $250 \mathrm{~mL}$ of dry THF, which was followed by the addition of $4.26 \mathrm{~g}$ ( $37 \mathrm{mmol}$ ) of NHS. Subsequently, $9.16 \mathrm{~g}$ (44 mmol) of DCC dissolved in $30 \mathrm{~mL}$ of dry THF was added dropwise. The mixture was stirred at room temperature for $24 \mathrm{~h}$; then, the precipitated DCU was filtered off under reduced pressure, and the filtrate was concentrated under reduced pressure. The residue was dissolved in $300 \mathrm{~mL}$ of $\mathrm{CHCl}_{3}$ and washed with a saturated solution of $\mathrm{NaHCO}_{3(\mathrm{aq})}$ $(2 \times 200 \mathrm{~mL})$ and water $(2 \times 200 \mathrm{~mL})$. The organic layer was dried over anhydrous $\mathrm{MgSO}_{4}$, the desiccant was filtered off, and the filtrate was concentrated under reduced pressure, obtaining $10.61 \mathrm{~g}(21 \mathrm{mmol}, 57 \%)$ of crude active ester $22 \mathrm{c}$, which was used in the next step without further purification.

Molecular umbrella-'trimethyl lock'-cargo conjugates (24a-d)—General Procedure, To a solution of $2.17 \mathrm{mmol}$ of carboxylic acid 19a-c in $20 \mathrm{~mL}$ of dry DMF, $568 \mu \mathrm{L}$ of DIPEA and $3.26 \mathrm{mmol}$ of DEPBT were added, respectively. The mixture was stirred at room temperature for $2 \mathrm{~h}$. Then, $100 \mathrm{~mL}$ of $\mathrm{CHCl}_{3}$ was added, and the resulting mixture was washed with $1 \mathrm{M}$ solution of $\mathrm{HCl}_{(\mathrm{aq})}(2 \times 75 \mathrm{~mL})$, brine $(2 \times 75 \mathrm{~mL})$, saturated 
solution of $\mathrm{NaHCO}_{3(\mathrm{aq})}(2 \times 75 \mathrm{~mL})$, and brine $(2 \times 75 \mathrm{~mL})$. The organic layer was dried over anhydrous $\mathrm{MgSO}_{4}$, the desiccant was filtered off, and the filtrate was concentrated under reduced pressure. The crude active ester was roughly purified by liquid column chromatography, using a mixture of solvents hexanes/AcOEt, 4/6, $v / v$ as a mobile phase. Then, $0.70 \mathrm{mmol}$ of active ester was dissolved in $20 \mathrm{~mL}$ of dry DMF, and then $1.1 \mathrm{~mL}$ of DIPEA and $1.05 \mathrm{mmol}$ of cispentacin were added, respectively. The mixture was stirred at room temperature for $2 \mathrm{~h}$. Subsequently, $100 \mathrm{~mL}$ of $\mathrm{CHCl}_{3}$ was added, and the resulting solution was washed with $1 \mathrm{M}$ solution of $\mathrm{HCl}_{(\mathrm{aq})}(3 \times 50 \mathrm{~mL})$ and brine $(3 \times 50 \mathrm{~mL})$. The organic layer was dried over anhydrous $\mathrm{MgSO}_{4}$, the desiccant was filtered off, and the filtrate was concentrated under reduced pressure, obtaining crude product 23a-c. Product 23a-c was dissolved in a mixture of DCM/TFA, 3/1, v/v and allowed to stir at room temperature for $1 \mathrm{~h}$. Then, the solvents were evaporated under reduced pressure, obtaining the crude deprotection product which was used in the next step without further purification. To the solution of $0.30 \mathrm{mmol}$ of deprotected spermidine derivative in dry DMF, $627 \mu \mathrm{L}$ of DIPEA and $0.60 \mathrm{mmol}$ of active ester $22 \mathbf{a}$ or $\mathbf{2 2} \mathbf{b}$ were added, respectively. The mixture was stirred at room temperature for $24 \mathrm{~h}$; then, the solvents were evaporated under reduced pressure, and the residue was treated with MeCN. The precipitate was collected by filtration under reduced pressure and purified by liquid column chromatography.

Molecular umbrella-cispentacin conjugate 24a, Starting from $700 \mathrm{mg}$ (1.1 mmol) of carboxylic acid 19a, $316 \mathrm{mg}(0.18 \mathrm{mmol}, 27 \%)$ of conjugate 24 a was obtained as a white solid, with $\mathrm{R}_{\mathrm{f}} 0.32\left(\mathrm{CHCl}_{3} / \mathrm{MeOH} / \mathrm{H}_{2} \mathrm{O}, 7 / 4 / 1, v / v / v\right) .{ }^{1} \mathrm{H}$ NMR (500 MHz, CD $\left.3 \mathrm{OD}\right) \delta: 6.82$ (s, $1 \mathrm{H}), 6.67(\mathrm{~s}, 1 \mathrm{H}), 4.67(\mathrm{~s}, 2 \mathrm{H}), 4.28(\mathrm{~m}, 3 \mathrm{H}), 2.44(\mathrm{~m}, 4 \mathrm{H}), 3.21(\mathrm{~m}, 4 \mathrm{H}), 2.96(\mathrm{~m}, 3 \mathrm{H}), 2.83(\mathrm{~m}$, $4 \mathrm{H}), 2.71(\mathrm{~m}, 1 \mathrm{H}), 2.60-4.42(\mathrm{~m}, 4 \mathrm{H}), 2.36-2.07(\mathrm{~m}, 9 \mathrm{H}), 2.01-0.86(\mathrm{~m}, 74 \mathrm{H}), 0.76(\mathrm{~s}, 6 \mathrm{H}) .{ }^{13} \mathrm{C}$ NMR (125 MHz, CD $\left.{ }_{3} \mathrm{OD}\right) \delta:$ 175.77, 175.53, 173.31, 172.39, 172.03, 163.52, 150.07, 138.06, 136.20, 133.59, 131.90, 122.96, 81.21, 79.37, 52.15, 48.51, 45.91, 45.36, 43.55, 42.31, 39.66, 38.50, $36.73,36.52,35.81,35.15,33.91,33.63,33.30,32.64,31.69,31.26,30.07,27.54,28.28,27.16$, $27.00,26.67,26.24,26.07,25.66,24.77,24.59,23.51,22.30,21.46,18.89,16.83,11.59$.

Molecular umbrella-cispentacin conjugate 24b, Starting from $525 \mathrm{mg}(0.69 \mathrm{mmol})$ of carboxylic acid 19a, $617 \mathrm{mg}(0.31 \mathrm{mmol}, 45 \%)$ of conjugate $24 \mathbf{b}$ was obtained as a white solid, with $\mathrm{R}_{\mathrm{f}} 0.29\left(\mathrm{CHCl}_{3} / \mathrm{MeOH} / \mathrm{H}_{2} \mathrm{O}, 7 / 4 / 1, v / v / v\right) .{ }^{1} \mathrm{H}$ NMR $\left(500 \mathrm{MHz}, \mathrm{CD}_{3} \mathrm{OD}\right) \delta$ : $6.82(\mathrm{~s}, 1 \mathrm{H}), 6.65(\mathrm{~s}, 1 \mathrm{H}), 4.66(\mathrm{~s}, 2 \mathrm{H}), 4.45(\mathrm{~m}, 2 \mathrm{H}), 4.25(\mathrm{~m}, 1 \mathrm{H}), 4.14(\mathrm{~m}, 2 \mathrm{H}), 3.41(\mathrm{~m}, 4 \mathrm{H})$, $3.19(\mathrm{~m}, 4 \mathrm{H}), 2.97-2.65(\mathrm{~m}, 6 \mathrm{H}), 2.53(\mathrm{~m}, 3 \mathrm{H}), 2.48-2.18(\mathrm{~m}, 14 \mathrm{H}), 2.11(\mathrm{~m}, 6 \mathrm{H}), 2.03-1.17$ $(\mathrm{m}, 46 \mathrm{H}), 1.15-0.86(\mathrm{~m}, 16 \mathrm{H}), 0.76(\mathrm{~s}, 6 \mathrm{H}) .{ }^{13} \mathrm{C} \mathrm{NMR}\left(125 \mathrm{MHz}, \mathrm{CD}_{3} \mathrm{OD}\right) \delta: 176.35,175.69$, $175.55,175.41,173.28,172.15,171.98,171.87,150.00,138.02,136.18,133.57,131.93,122.98$, $116.89,80.77,79.37,76.43,52.09,48.48,46.12,45.84,45.25,43.42,42.23,41.89,39.47,39.16$, $38.54,38.44,36.47,35.67,35.40,35.10,34.10,32.81,32.62,31.72,31.28,31.12,30.29,30.06$, $29.01,28.18,27.58,27.42,27.30,27.16,27.00,26.29,25.64,24.59,24.46,22.49,21.78,21.48$, $18.93,16.88,11.58$.

Molecular umbrella-cispentacin conjugate 24c, Starting from $270 \mathrm{mg}$ (0.39 mmol) of carboxylic acid 19b, $187 \mathrm{mg}(0.09 \mathrm{mmol}, 23 \%)$ of conjugate $24 \mathrm{c}$ was obtained as a white solid with $\mathrm{R}_{\mathrm{f}} 0.25\left(\mathrm{CHCl}_{3} / \mathrm{MeOH} / \mathrm{H}_{2} \mathrm{O}, 7 / 4 / 1, v / v / v\right)$. ${ }^{1} \mathrm{H} \mathrm{NMR}\left(500 \mathrm{MHz}, \mathrm{CD}_{3} \mathrm{OD}\right)$ $\delta: 6.84(\mathrm{~s}, 1 \mathrm{H}), 6.61(\mathrm{~s}, 1 \mathrm{H}), 4.68(\mathrm{~s}, 2 \mathrm{H}), 4.47(\mathrm{~s}, 2 \mathrm{H}), 4.26(\mathrm{~m}, 1 \mathrm{H}), 4.15(\mathrm{~m}, 2 \mathrm{H}), 3.40(\mathrm{~m}$, $4 \mathrm{H}), 3.21(\mathrm{~m}, 4 \mathrm{H}), 2.78(\mathrm{~m}, 1 \mathrm{H}), 2.68(\mathrm{~m}, 3 \mathrm{H}), 2.53(\mathrm{~s}, 3 \mathrm{H}), 2.50-2.24(\mathrm{~m}, 13 \mathrm{H}), 2.23(\mathrm{~s}, 3 \mathrm{H})$, 2.15-2.05 (m, 5H), 2.05-1.20 (m, 55H), 1.15-0.98 (m, 10H), $0.95(\mathrm{~s}, 6 \mathrm{H}), 0.77(\mathrm{~s}, 6 \mathrm{H}) .{ }^{13} \mathrm{C}$

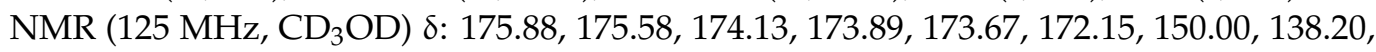
$136.35,133.43,132.09,123.14,81.23,79.82,76.84,52.21,48.67,48.50,45.88,42.29,41.86,39.61$, $39.17,38.45,36.70,35.74,35.45,35.03,34.28,34.15,32.78,32.44,31.86,31.28,31.07,30.36$, $29.32,28.57,27.61,27.44,27.15,26.90,26.32,25.94,25.02,24.60,24.50,24.16,22.48,21.73$, 21.41, 18.92, 16.92, 16.87, 11.50 .

Molecular umbrella-cispentacin conjugate $24 \mathrm{~d}$, Starting from $1.02 \mathrm{~g}$ (1.44 mmol) of carboxylic acid 19c, $824 \mathrm{mg}(0.39 \mathrm{mmol}, 27 \%)$ of conjugate $24 \mathrm{~d}$ was obtained as a white solid with $\mathrm{R}_{\mathrm{f}} 0.25\left(\mathrm{CHCl}_{3} / \mathrm{MeOH} / \mathrm{H}_{2} \mathrm{O}, 7 / 4 / 1, v / v / v\right) .{ }^{1} \mathrm{H} \mathrm{NMR}\left(500 \mathrm{MHz}, \mathrm{CD}_{3} \mathrm{OD}\right) \delta: 6.86$ (s, $1 \mathrm{H}), 6.60(\mathrm{~s}, 1 \mathrm{H}), 4.68(\mathrm{~s}, 2 \mathrm{H}), 4.47(\mathrm{~s}, 2 \mathrm{H}), 4.28(\mathrm{~m}, 1 \mathrm{H}), 4.15(\mathrm{~m}, 2 \mathrm{H}), 3.40(\mathrm{~m}, 4 \mathrm{H}), 3.18(\mathrm{~m}$, $4 \mathrm{H}), 2.94-2.61(\mathrm{~m}, 4 \mathrm{H}), 2.55(\mathrm{~s}, 3 \mathrm{H}), 2.49-2.27(\mathrm{~m}, 12 \mathrm{H}), 2.24(\mathrm{~s}, 3 \mathrm{H}), 2.11(\mathrm{~m}, 11 \mathrm{H}), 2.03-1.19$ 
$(\mathrm{m}, 50 \mathrm{H}), 1.07(\mathrm{~m}, 10 \mathrm{H}), 0.95(\mathrm{~m}, 6 \mathrm{H}), 0.77(\mathrm{~m}, 6 \mathrm{H}) .{ }^{13} \mathrm{C}$ NMR $\left(125 \mathrm{MHz}, \mathrm{CD}_{3} \mathrm{OD}\right) \delta: 175.93$, $175.65,174.17,173.90,164.92,164.40,151.30,138.08,135.99,134.83,133.28,123.16,81.19$, $79.94,76.81,53.22,48.54,46.09,45.80,44.05,42.15,39.54,39.33,38.42,36.58,35.57,35.46$, $35.01,34.32,34.06,32.61,32.44,31.86,31.28,31.10,30.34,30.04,28.55,27.41,27.26,26.28$, $25.92,25.14,24.49,24.13,23.51,23.71,22.99,21.93,21.92,21.46,18.97,16.51,11.50$.

Molecular umbrella-Lys(Mca) conjugate 26a, Starting from $292 \mathrm{mg}$ (0.45 mmol) of carboxylic acid 19a, $210 \mathrm{mg}(0.13 \mathrm{mmol}, 29 \%)$ of conjugate $26 \mathrm{a}$ was obtained. The product was purified by liquid column chromatography using a mixtures of solvents $\mathrm{CHCl}_{3} / \mathrm{MeOH} / \mathrm{H}_{2} \mathrm{O}$, 65/10/1, $v / v / v$ and $\mathrm{CHCl}_{3} / \mathrm{MeOH} / \mathrm{H}_{2} \mathrm{O}, 7 / 4 / 1, v / v / v$ as mobile phases. HRMS-ESI: $m / z$ calcd. for $\mathrm{C}_{90} \mathrm{H}_{135} \mathrm{~N}_{5} \mathrm{O}_{18}$ 1573.9802; found $1574.9853[\mathrm{M}+1]^{+} .{ }^{1} \mathrm{H}$ NMR $\left(500 \mathrm{MHz}, \mathrm{CD}_{3} \mathrm{OD}\right)$ $\delta: 7.68(\mathrm{~d}, J=8.9 \mathrm{~Hz}, 1 \mathrm{H}), 6.96(\mathrm{~m}, 1 \mathrm{H}), 6.91(\mathrm{~s}, 1 \mathrm{H}), 6.81(\mathrm{~s}, 1 \mathrm{H}), 6.63(\mathrm{~s}, 1 \mathrm{H}), 6.26(\mathrm{~s}, 1 \mathrm{H})$, $4.17(\mathrm{~m}, 1 \mathrm{H}), 3.94(\mathrm{~s}, 2 \mathrm{H}), 3.88(\mathrm{~s}, 3 \mathrm{H}), 3.79(\mathrm{~s}, 2 \mathrm{H}), 3.74(\mathrm{~s}, 2 \mathrm{H}), 3.36(\mathrm{~m}, 6 \mathrm{H}), 3.24-3.08(\mathrm{~m}$, $6 \mathrm{H}), 2.91(\mathrm{~m}, 2 \mathrm{H}), 2.81(\mathrm{~m}, 3 \mathrm{H}), 2.55(\mathrm{~s}, 4 \mathrm{H}), 2.27(\mathrm{~m}, 6 \mathrm{H}), 2.18-1.19(\mathrm{~m}, 57 \mathrm{H}), 1.18-0.85(\mathrm{~m}$, $18 \mathrm{H}), 0.86(\mathrm{~s}, 6 \mathrm{H}) .{ }^{13} \mathrm{C} \mathrm{NMR}\left(125 \mathrm{MHz}, \mathrm{CD}_{3} \mathrm{OD}\right) \delta: 175.37,172.99,171.95,169.04,163.16$, $161.67,155.34,151.13,150.04,138.09,136.01,133.65,131.91,126.05,122.81,112.68,100.47$, $78.09,72.51,71.42,67.55,55.18,54.73,46.57,46.02,41.87,41.46,39.57,39.16,39.03,38.83$, $36.41,35.56,35.09,34.51,32.77,31.92,31.18,30.00,29.75,29.31,28.45,28.21,27.57,27.39$, $27.19,26.47,26.31,22.57,24.52,22.83,22.45,21.85,19.01,16.37,11.66$.

Molecular umbrella-Lys (Mca) conjugate 26b, Starting from $221 \mathrm{mg}(0.34 \mathrm{mmol})$ of carboxylic acid 19a, $219 \mathrm{mg}(0.10 \mathrm{mmol}, 29 \%)$ of conjugate $\mathbf{2 6 b}$ was obtained. The product was purified by liquid column chromatography using a mixture of solvents $\mathrm{CHCl}_{3} / \mathrm{MeOH} / \mathrm{H}_{2} \mathrm{O}$, $7 / 4 / 1, v / v / v$ as a mobile phase. ${ }^{1} \mathrm{H}$ NMR $\left(500 \mathrm{MHz}, \mathrm{CD}_{3} \mathrm{OD}\right) \delta: 7.72(\mathrm{~d}, J=8.9 \mathrm{~Hz}, 1 \mathrm{H})$, $6.98(\mathrm{~m}, 1 \mathrm{H}), 6.91(\mathrm{~s}, 1 \mathrm{H}), 6.79(\mathrm{~s}, 1 \mathrm{H}), 6.65(\mathrm{~s}, 1 \mathrm{H}), 6.29(\mathrm{~s}, 1 \mathrm{H}), 4.66(\mathrm{~s}, 2 \mathrm{H}), 4.44(\mathrm{~s}, 2 \mathrm{H})$, $4.13(\mathrm{~m}, 3 \mathrm{H}), 3.90(\mathrm{~s}, 3 \mathrm{H}), 3.77(\mathrm{~s}, 2 \mathrm{H}), 3.40(\mathrm{~m}, 4 \mathrm{H}), 3.19(\mathrm{~m}, 6 \mathrm{H}), 2.90(\mathrm{~m}, 2 \mathrm{H}), 2.82(\mathrm{~m}$, $3 \mathrm{H}), 2.56-1.18(\mathrm{~m}, 67 \mathrm{H}), 1.18-0.87(\mathrm{~m}, 18 \mathrm{H}), 0.74(\mathrm{~m}, 6 \mathrm{H}) .{ }^{13} \mathrm{C} \mathrm{NMR}\left(125 \mathrm{MHz}, \mathrm{CD}_{3} \mathrm{OD}\right) \delta$ : $175.48,173.21,172.06,169.00,163.50,163.19,161.74,155.17,151.35,149.91,137.98,136.08$, 133.56, 131.87, 126.15, 122.85, 112.63, 112.39, 112.24, 100. 56, 81.01, 79.86, 76.43, 55.10, 53.75, $48.39,46.03,45.16,43.45,42.37,42.30,41.94,39.51,39.23,38.73,38.36,36.44,34.57,34.93$, $34.08,32.78,31.64,31.16,30.33,30.22,30.09$, 28.96, 28.53, 28.19, 27.61, 27.46, 27.31, 27.18, 26.27, 25.66, 24.64, 24.47, 22.47, 21.77, 18.95, 16.85, 11.53.

Molecular umbrella-Nap- $\mathrm{NH}_{2}$ conjugate 27, Starting from $580 \mathrm{mg}(0.82 \mathrm{mmol})$ of carboxylic acid 19c, $900 \mathrm{mg}(0.41 \mathrm{mmol}, 50 \%)$ of fluorescent conjugate 27 was obtained as an orange solid with $\mathrm{R}_{\mathrm{f}} 0.29\left(\mathrm{CHCl}_{3} / \mathrm{MeOH} / \mathrm{H}_{2} \mathrm{O}, 7 / 4 / 1, v / v / v\right)$. ${ }^{1} \mathrm{H} \mathrm{NMR}(500 \mathrm{MHz}$, $\left.\mathrm{CD}_{3} \mathrm{OD}\right) \delta: 8.52(\mathrm{~d}, J=7.5 \mathrm{~Hz}, 1 \mathrm{H}), 8.39(\mathrm{dd}, J=8.2 \mathrm{~Hz}, 3.1 \mathrm{~Hz}, 1 \mathrm{H}), 8.35(\mathrm{~d}, J=8.7 \mathrm{~Hz}, 1 \mathrm{H})$, $8.07(\mathrm{t}, J=5.5 \mathrm{~Hz}, 1 \mathrm{H}), 7.98(\mathrm{~m}, 1 \mathrm{H}), 7.76(\mathrm{~m}, 1 \mathrm{H}), 7.64(\mathrm{t}, J=7.9 \mathrm{~Hz}, 1 \mathrm{H}), 6.71(\mathrm{~d}, J=8.9 \mathrm{~Hz}$, $1 \mathrm{H}), 6.61(\mathrm{~m}, 1 \mathrm{H}), 6.38(\mathrm{~s}, 1 \mathrm{H}), 4.66(\mathrm{~m}, 2 \mathrm{H}), 4.62(\mathrm{brs}, 1 \mathrm{H}), 4.44(\mathrm{~m}, 2 \mathrm{H}), 4.13(\mathrm{~m}, 4 \mathrm{H}), 3.53$ $(\mathrm{m}, 2 \mathrm{H}), 3.19(\mathrm{~m}, 4 \mathrm{H}), 2.72(\mathrm{~m}, 2 \mathrm{H}), 2.53(\mathrm{~m}, 2 \mathrm{H}), 2.44(\mathrm{~m}, 4 \mathrm{H}), 2.35(\mathrm{~m}, 9 \mathrm{H}), 2.22(\mathrm{~m}, 2 \mathrm{H})$, $2.12(\mathrm{~m}, 6 \mathrm{H}), 1.98(\mathrm{~m}, 7 \mathrm{H}), 1.92-1.30(\mathrm{~m}, 47 \mathrm{H}), 1.23(\mathrm{~m}, 7 \mathrm{H}), 1.14-0.96(\mathrm{~m}, 13 \mathrm{H}), 0.92(\mathrm{~m}, 6 \mathrm{H})$, $0.73(\mathrm{~m}, 6 \mathrm{H}) .{ }^{13} \mathrm{C}$ NMR $\left(125 \mathrm{MHz}, \mathrm{CD}_{3} \mathrm{OD}\right) \delta: 175.93,175.65,174.17,173.90,164.92,164.40$, $151.30,149.75,138.08,135.99,134.83,133.28,131.93,131.07,129.63,128.56,124.44,122.89$, $121.68,120.27,107.92,103.66,81.19,79.94,76.81,60.97,48.54,46.09,45.80,44.05,42.15,41.74$, $39.54,39.33,39.15,38.42,37.75,36.58,35.57,35.46,35.01,34.32,34.06,32.61,31.77,31.10$, $30.34,30.04,28.55,27.41,27.26,26.28,25.92,25.14,24.49,24.13,22.51,21.71,19.99,18.93$, $16.92,15.46,12.97,11.51$.

$\left\{N, N^{\prime}\right.$-bis[4-(tert-butoxycarbonyl)amino]butyl-N,N'-bis[3-(tert-butylcarbonyl)amino]propyl $\}$ $3,3^{\prime}$-dithiodipropanoic amide 29, To a suspension of $1.76 \mathrm{~g}(4.34 \mathrm{mmol}$ ) of diester 28 in $50 \mathrm{~mL}$ of THF, $2 \mathrm{~mL}(8.68 \mathrm{mmol})$ of DIPEA and $3 \mathrm{~g}(8.68 \mathrm{mmol})$ of protected spermidine 16 was added, respectively. The mixture was stirred at room temperature for $24 \mathrm{~h}$, and then, the solvents were evaporated under reduced pressure. The residue was dissolved in $75 \mathrm{~mL}$ of $\mathrm{CHCl}_{3}$ and washed with a saturated solution of $\mathrm{NaHCO}_{3(\mathrm{aq})}(2 \times 50 \mathrm{~mL})$, brine $(2 \times 50 \mathrm{~mL})$, $5 \%$ solution of $\mathrm{NaHSO}_{4(\mathrm{aq})}(2 \times 50 \mathrm{~mL})$, and brine $(2 \times 50 \mathrm{~mL})$, respectively. The organic layer was dried over anhydrous $\mathrm{MgSO}_{4}$, the desiccant was filtered off, and the filtrate was concentrated under reduced pressure. The residue was purified by liquid column chromatography using a mixture of solvents $\mathrm{CHCl}_{3} / \mathrm{MeOH} / \mathrm{H}_{2} \mathrm{O}, 65 / 10 / 11, v / v / v$ as a 
mobile phase, obtaining $2.89 \mathrm{~g}(3.34 \mathrm{mmol}, 77 \%)$ of product 29 as a colorless oil with $\mathrm{R}_{\mathrm{f}}$ $0.70\left(\mathrm{CHCl}_{3} / \mathrm{MeOH} / \mathrm{H}_{2} \mathrm{O}, 65 / 10 / 11, v / v / v\right)$. HRMS-ESI: $m / z$ calcd. for $\mathrm{C}_{40} \mathrm{H}_{76} \mathrm{~N}_{6} \mathrm{O}_{10} \mathrm{~S}_{2}$ 864.5064; found 865.5112 [M + 1] ${ }^{+}$. ${ }^{1} \mathrm{H} \mathrm{NMR}\left(500 \mathrm{MHz}, \mathrm{CDCl}_{3}\right) \delta: 3.52-3.22(\mathrm{~m}, 8 \mathrm{H})$, 3.20-3.01 (m, 8H), $2.96(\mathrm{~m}, 4 \mathrm{H}), 2.74(\mathrm{~m}, 4 \mathrm{H}), 1.83-1.31(\mathrm{~m}, 48 \mathrm{H}) .{ }^{13} \mathrm{C}$ NMR $(125 \mathrm{MHz}$, $\left.\mathrm{CDCl}_{3}\right) \delta: 171.16,170.43,156.09,79.21,78.88,49.02,47.48,45.66,45.49,42.73,40.11,39.89$, $38.01,37.29,34.03,33.88,32.89,37.78,32.63,32.52,29.99,28.47,28.43,27.94,27.67,27.49$, 26.16, 25.66, 24.94.

$N^{1}, N^{7}$-bis(tert-butoxycarbonyl)-N $N^{3}$-(3-thiopropanoyl)spermidine 30 , To a solution of $2.4 \mathrm{~g}$ $(2.78 \mathrm{mmol})$ of spermidine derivative 29 in $50 \mathrm{~mL}$ of $\mathrm{MeOH}, 1.20 \mathrm{~g}$ (4.18 mmol) of TCEP solution in $10 \mathrm{~mL}$ of water, adjusted to $\mathrm{pH} 7$ with $\mathrm{NaHCO}_{3}$, was added. The mixture was stirred at room temperature for $1 \mathrm{~h}$, and then, $\mathrm{MeOH}$ was evaporated under reduced pressure. The aqueous residue was extracted with $\mathrm{CHCl}_{3}(3 \times 25 \mathrm{~mL})$. The organic layer was dried over anhydrous $\mathrm{MgSO}_{4}$, the desiccant was filtered off, and the filtrate was concentrated under reduced pressure. The residue was purified by liquid column chromatography using a mixture of solvents hexanes / AcOEt, 3/7, $v / v$ as a mobile phase

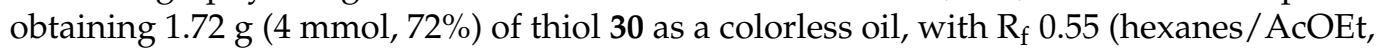
3/7,v/v). HRMS-ESI: $m / z$ calcd. for $\mathrm{C}_{20} \mathrm{H}_{39} \mathrm{~N}_{3} \mathrm{O}_{5} \mathrm{~S} 433.2610$; found $434.2623[\mathrm{M}+1]^{+} .{ }^{1} \mathrm{H}$ NMR (500 MHz, CDCl $)$ ): 6.95-6.63 (m, 2H), $3.21(\mathrm{~m}, 4 \mathrm{H}), 2.91(\mathrm{~m}, 4 \mathrm{H}), 2.63(\mathrm{~m}, 4 \mathrm{H}), 2.29$ $(\mathrm{m}, 1 \mathrm{H}), 1.77-1.22$ (m, $24 \mathrm{H}) .{ }^{13} \mathrm{C}$ NMR $\left(125 \mathrm{MHz}, \mathrm{CDCl}_{3}\right) \delta: 170.48,170.23,156.10,79.69$, $77.89,60.28,47.25,45.20,45.00,43.27,38.13,36.78,29.28,28.73,28.26,27.58,27.23,26.30$, $25.20,20.39$.

$N^{1}, N^{7}$-bis(tert-butoxycarbonyl)-N $N^{3}$-[3-(o-hydroxymethylphenyl)dithio]propanoyl]spermidine 32, First, $1.56 \mathrm{~g}$ ( $3.60 \mathrm{mmol}$ ) of thiol 30 was dissolved in $20 \mathrm{~mL}$ of dry $\mathrm{MeOH}$, and then, $1 \mathrm{~mL}(7.42 \mathrm{mmol})$ of TEA and $995 \mathrm{mg}(4.32 \mathrm{mmol})$ of activated disulfide 31 were added, respectively. The mixture was stirred at room temperature for $2 \mathrm{~h}$, and then, the solvents were evaporated under reduced pressure. The residue was dissolved in $50 \mathrm{~mL}$ of $\mathrm{CHCl}_{3}$ and washed with a saturated solution of $\mathrm{NaHCO}_{3(\mathrm{aq})}(2 \times 50 \mathrm{~mL})$, water $(2 \times 50 \mathrm{~mL})$, $5 \%$ solution of $\mathrm{NaHSO}_{4(\mathrm{aq})}(2 \times 50 \mathrm{~mL})$, and water $(2 \times 50 \mathrm{~mL})$, respectively. The organic layer was dried over anhydrous $\mathrm{MgSO}_{4}$, the desiccant was filtered off, and the filtrate was concentrated under reduced pressure. The residue was purified by liquid column chromatography, using a mixture of solvents hexanes / AcOEt, 3/7, $v / v$ as a mobile phase, obtaining $610 \mathrm{mg}(1.07 \mathrm{mmol}, 30 \%)$ of disulfide 32 as a colorless oil, with $\mathrm{R}_{\mathrm{f}} 0.50$ (hexanes / AcOEt, 3/7, v/v). HRMS-ESI: $m / z$ calcd. for $\mathrm{C}_{27} \mathrm{H}_{45} \mathrm{~N}_{3} \mathrm{O}_{6} \mathrm{~S}_{2}$ 571.2750; found 572.2698 $[\mathrm{M}+1]^{+} .{ }^{1} \mathrm{H}$ NMR $\left(500 \mathrm{MHz}, \mathrm{DMSO}-d_{6}\right) \delta: 7.69(\mathrm{~m}, 1 \mathrm{H}), 7.46(\mathrm{~d}, J=7.2 \mathrm{~Hz}, 1 \mathrm{H}), 7.30(\mathrm{~m}$, $2 \mathrm{H}), 6.93-6.66(\mathrm{~m}, 2 \mathrm{H}), 5.31(\mathrm{t}, J=5.4 \mathrm{~Hz}, 1 \mathrm{H}), 4.59(\mathrm{~d}, J=5.4 \mathrm{~Hz}, 2 \mathrm{H}), 3.24-2.99(\mathrm{~m}, 6 \mathrm{H})$, 2.92-2.83 (m, 4H), $2.65(\mathrm{~m}, 2 \mathrm{H}), 1.59-1.42(\mathrm{~m}, 3 \mathrm{H}), 1.33-1.20(\mathrm{~m}, 3 \mathrm{H}), 1.37(\mathrm{~s}, 18 \mathrm{H}) .{ }^{13} \mathrm{C}$ NMR $\left.(125 \mathrm{MHz}, \text { DMSO-d })_{6}\right) \delta: 170.96,170.31,156.08,140.30,135.26,128.34,127.53,78.96$, $70.75,62.74,60.52,47.36,45.42,42.78,39.98,33.91,32.20,28.47,27.55,26.46,26.12,24.97$, $21.11,14.16$.

Molecular umbrella-o-dithobenzoylcarbamoyl linker-cargo conjugates (35 and 37)_General Procedure, To a solution of $1.05 \mathrm{mmol}$ of disulfide 32 in $10 \mathrm{~mL}$ of MeCN, $1.05 \mathrm{mmol}$ of TEA and $1.05 \mathrm{mmol}$ of DSC were added, respectively. The mixture was stirred at room temperature for $2 \mathrm{~h}$, and then, solvents were evaporated under reduced pressure. The residue was dissolved in $50 \mathrm{~mL}$ of AcOEt and washed with water $(2 \times 20 \mathrm{~mL})$. The organic layer was dried over anhydrous $\mathrm{MgSO}_{4}$, the desiccant was filtered off, and the filtrate was concentrated under reduced pressure. The residue was dissolved in $10 \mathrm{~mL}$ of $\mathrm{MeCN}$ and then transferred to the mixture of $1.58 \mathrm{mmol}$ of a cargo molecule and $2.10 \mathrm{mmol}$ of TEA dissolved in $10 \mathrm{~mL}$ of water. The mixture was stirred at room temperature for $2 \mathrm{~h}$, and then, MeCN was evaporated under reduced pressure. The remaining aqueous residue was acidified with $1 \mathrm{M} \mathrm{HCl}_{(\mathrm{aq})}$ to $\mathrm{pH} 2$, and the resulting solution was extracted with AcOEt $(4 \times 20 \mathrm{~mL})$. The organic layer was dried over anhydrous $\mathrm{MgSO}_{4}$, the desiccant was filtered off, and the filtrate was concentrated under reduced pressure. The residue was roughly purified by liquid column chromatography, using a mixture of solvents $\mathrm{CHCl}_{3} / \mathrm{MeOH} / \mathrm{H}_{2} \mathrm{O}, 65 / 10 / 1, v / v / v$ as a mobile phase, obtaining $0.62 \mathrm{mmol}$ of a crude 
product as an oil. The resulting oil was dissolved in $8 \mathrm{~mL}$ of DCM/TFA, 3/1, v/v mixture and was allowed to stir at room temperature for $1 \mathrm{~h}$. Subsequently, the solvents were evaporated, and the residue was dissolved in $20 \mathrm{~mL}$ of dry DMF. Then, $220 \mu$ of DIPEA and $1.24 \mathrm{mmol}$ of $\mathbf{2 2} \mathbf{b}$ were added, respectively. The mixture was stirred at room temperature for $5 \mathrm{~h}$, and then, most of the solvents were evaporated under reduced pressure, and $\mathrm{MeCN}$ was added to the residue. The precipitate was collected and purified by liquid column chromatography using a mixture of solvents $\mathrm{CHCl}_{3} / \mathrm{MeOH} / \mathrm{H}_{2} \mathrm{O}, 5 / 4 / 1$, v/v/v as a mobile phase.

Molecular umbrella-o-dithobenzoylcarbamoyl linker-cispentacin conjugate 35, Starting from $600 \mathrm{mg}$ (1.05 mmol) of disulfide 32, $230 \mathrm{mg}(0.12 \mathrm{mmol}, 11 \%)$ of conjugate 35 was obtained as a beige solid, with $\mathrm{R}_{\mathrm{f}} 0.30\left(\mathrm{CHCl}_{3} / \mathrm{MeOH} / \mathrm{H}_{2} \mathrm{O}, 5 / 4 / 1, v / v / v\right) .{ }^{1} \mathrm{H} \mathrm{NMR}(500 \mathrm{MHz}$, $\left.\mathrm{CD}_{3} \mathrm{OD}\right) \delta: 8.00(\mathrm{~m}, 2 \mathrm{H}), 7.80(\mathrm{~m}, 1 \mathrm{H}), 7.52-7.37(\mathrm{~m}, 2 \mathrm{H}), 7.32(\mathrm{~m}, J=6.1 \mathrm{~Hz}, 1 \mathrm{H}), 5.41-5.17$ $(\mathrm{m}, 2 \mathrm{H}), 4.66(\mathrm{~s}, 2 \mathrm{H}), 4.46(\mathrm{~s}, 2 \mathrm{H}), 4.16(\mathrm{~m}, 3 \mathrm{H}), 3.35(\mathrm{~m}, 2 \mathrm{H}), 3.18(\mathrm{~m}, 6 \mathrm{H}), 3.01(\mathrm{~m}, 2 \mathrm{H})$, $2.89(\mathrm{~m}, 1 \mathrm{H}), 2.75(\mathrm{t}, 2 \mathrm{H}), 2.49-2.22(\mathrm{~m}, 10 \mathrm{H}), 2.10(\mathrm{~m}, 6 \mathrm{H}), 2.04-1.20(\mathrm{~m}, 42 \mathrm{H}), 1.17-0.98$ $(\mathrm{m}, 10 \mathrm{H}), 0.95(\mathrm{~s}, 6 \mathrm{H}), 0.76(\mathrm{~s}, 6 \mathrm{H}) .{ }^{13} \mathrm{C}$ NMR $\left(125 \mathrm{MHz}, \mathrm{CD}_{3} \mathrm{OD}\right) \delta: 175.74,164.79,129.80$, 128.70, 127.30, 125.61, 109.81, 81.06, 79.81, 76.60, 63.79, 54.28, 48.47, 46.06, 45.96, 45.38, 42.22, $42.04,39.31,35.68,35.47,35.11,34.43,34.11,32.71,31.99,31.80,31.62,30.30,29.40,28.94$, $28.29,27.61,27.43,27.35,27.15,26.37,25.80,24.60,22.52,21.79,16.89,11.56$.

Molecular umbrella-o-dithobenzoylcarbamoyl linker-Lys(Mca) conjugate 37, Starting from $630 \mathrm{mg}(1.10 \mathrm{mmol})$ of disulfide $32,230 \mathrm{mg}(0.11 \mathrm{mmol}, 10 \%)$ of conjugate 37 was obtained as a light-yellow solid, with $\mathrm{R}_{\mathrm{f}} 0.50\left(\mathrm{CHCl}_{3} / \mathrm{MeOH} / \mathrm{H}_{2} \mathrm{O}, 5 / 4 / 1, v / v / v\right) .{ }^{1} \mathrm{H} \mathrm{NMR}(500 \mathrm{MHz}$, $\left.\mathrm{CD}_{3} \mathrm{OD}\right) \delta: 8.82(\mathrm{~s}, 1 \mathrm{H}), 7.78(\mathrm{~m}, 2 \mathrm{H}), 7.42(\mathrm{~d}, J=7.5 \mathrm{~Hz}, 1 \mathrm{H}), 7.38(\mathrm{t}, J=7.3 \mathrm{~Hz}, 1 \mathrm{H}), 7.30(\mathrm{t}$, $J=7.6 \mathrm{~Hz}, 1 \mathrm{H}), 7.04(\mathrm{~m}, 1 \mathrm{H}), 6.98(\mathrm{~m}, 1 \mathrm{H}), 5.24(\mathrm{~m}, 2 \mathrm{H}), 4.65(\mathrm{~m}, 2 \mathrm{H}), 4.46(\mathrm{~m}, 2 \mathrm{H}), 4.16(\mathrm{~m}$, $2 \mathrm{H}), 3.96(\mathrm{~m}, 3 \mathrm{H}), 3.51(\mathrm{~m}, 2 \mathrm{H}), 3.37(\mathrm{~m}, 2 \mathrm{H}), 3.30-3.12(\mathrm{~m}, 8 \mathrm{H}), 3.01(\mathrm{~m}, 2 \mathrm{H}), 2.78(\mathrm{~m}, 2 \mathrm{H})$, $2.47-2.20(\mathrm{~m}, 10 \mathrm{H}), 2.20-1.18(\mathrm{~m}, 42 \mathrm{H}), 1.14-0.84(\mathrm{~m}, 16 \mathrm{H}), 0.74(\mathrm{~m}, 6 \mathrm{H})$.

\subsection{Microbial Strains and Culture Conditions}

The reference strains used in this study were Candida albicans ATCC 10231, Candida glabrata DSM 11226, and Candida krusei DSM 6128. C. albicans B3, B4, Gu4, and Gu5 clinical isolates were kindly provided by Joachim Morschhäuser, Würzburg, Germany. Gu4 and B3 are fluconazole-sensitive isolates obtained from early infection episodes, while Gu5 and $\mathrm{B} 4$ are the corresponding fluconazole-resistant isolates obtained from later episodes in the same patients treated with fluconazole [24]. Strains were grown at $30{ }^{\circ} \mathrm{C}$ in YPD medium (2\% glucose, 1\% yeast extract, and 1\% Bacto-Peptone) and stored on YPD agar plates containing $2 \%$ agar.

\subsection{Antifungal In Vitro Activity Determination}

Susceptibility testing was performed in two growth media: (a) RPMI-1640 w/o sodium bicarbonate, with L-glutamine $+2 \%$ glucose $+3.45 \%$ MOPS, $\mathrm{pH}$ adjusted to 7.0 ; (b) YNB-AS-Yeast Nitrogen Base $w / o$ amino acids (contains ammonium sulfate $5 \mathrm{~g} \mathrm{~L}^{-1}$ ) $+2 \%$ glucose. The in vitro growth inhibitory activity of antifungals was quantified by determination of $\mathrm{MIC}_{50}$ and $\mathrm{MIC}_{90}$ values by the serial two-fold dilution method, using the 96-well microtiter plates. Serial dilutions of cispentacin and its conjugates were prepared in the $4-0.015 \mathrm{mM}$ range.

Conditions of the RPMI-1640-based assay were the same as outlined in the CLSI recommendations [25] except for the end-point readout that was done by spectrophotometric determination of cell density at $660 \mathrm{~nm}$. Turbidity in individual wells was measured with a microplate reader (Victor ${ }^{3}$; Perkin Elmer). The 96-well microtiter plates were also used for the determination of in vitro growth inhibitory activity in YNB-AS medium. Individual wells were inoculated with $5 \times 10^{3}$ Candida cells $\mathrm{mL}^{-1}$ from the overnight culture in YPD medium. The plates were incubated at $37^{\circ} \mathrm{C}$ for $24 \mathrm{~h}$, and then, turbidity was measured with a microplate reader at $660 \mathrm{~nm}$, as described above for the RPMI-1640-based assay. 
Values of $\mathrm{MIC}_{50}$ and $\mathrm{MIC}_{90}$ were read from the graphs of $\mathrm{A}_{660}$ vs. drug concentration and corresponded to the interpolated values of drug concentration at which $\mathrm{A}_{660}$ was $50 \%$ or $10 \%$ of that measured for the drug-free control.

\subsection{Hemolytic Activity Determination}

Red blood cell concentrates were kindly provided by the Regional Center for Blood Donation and Blood Treatment in Gdańsk. The hemolytic activity determination was carried out by the serial dilution method, according to the procedure described earlier [26]. Briefly,

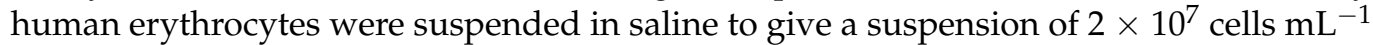
(hemocytometer count). The stock $1 \mathrm{mg} \mathrm{mL}^{-1}$ solutions of conjugates were prepared in DMSO, and $50 \mu \mathrm{L}$ aliquots of serial two-fold dilutions were placed in Eppendorf tubes. Tubes containing $50 \mu \mathrm{L}$ of DMSO and $50 \mu \mathrm{L}$ of $2 \%$ aqueous Triton $X-100$ solution were included as a negative and positive control, respectively. To each tube, $950 \mu \mathrm{L}$ of the erythrocyte suspension was added and mixed by inversion to give the final concentrations of compounds tested in the $200-0.4 \mu \mathrm{g} \mathrm{mL}{ }^{-1}$ range. The samples were incubated at $37^{\circ} \mathrm{C}$ for $30 \mathrm{~min}$; then, they were mixed by inversion and centrifuged $\left(1700 \times g, 5 \mathrm{~min}, 4^{\circ} \mathrm{C}\right)$. The concentration of hemoglobin in supernatants obtained after the centrifugation of erythrocytes suspension was determined by measuring the absorbance at wavelength $\lambda=540 \mathrm{~nm}$ $\left(\mathrm{A}_{540}{ }^{\text {sample }}\right)$. Absorbance of the negative $\left(\mathrm{A}_{540}{ }^{\mathrm{DMSO}}\right)$ and the positive $\left(\mathrm{A}_{540}{ }^{0.1 \% \text { Triton } X-100}\right)$ controls was also measured. The percent of hemolysis at a given compound concentration/EH (\%)/was calculated as follows:

$$
\mathrm{EH}(\%)=\left(\left(\mathrm{A}_{540}{ }^{\text {sample }}-\mathrm{A}_{540}{ }^{\mathrm{DMSO}}\right) /\left(\mathrm{A}_{540} 0.1 \% \text { Triton } \mathrm{X}-100-\mathrm{A}_{540}{ }^{\mathrm{DMSO}}\right)\right) \times 100 .
$$

The $\mathrm{EH}_{50}$ values for each compound were calculated with the GraphPad Prism software as an interpolated concentration of compound, for which the $\mathrm{A}_{540}$ value is exactly $50 \%$ of the $A_{540}$ value measured for the positive control sample.

\subsection{Preparation of C. albicans Cell-Free Extracts}

C. albicans cells were harvested from the culture in YPD medium in the logarithmic phase of growth and washed with PBS, pH 7.4. Then, cells were suspended in a minimal amount of PBS to an optical density $\mathrm{OD}_{660} \approx 1.5$. A sample of $1.5 \mathrm{~mL}$ of the cell suspension was put into the Lysing Matrix D, $2 \mathrm{~mL}$ tubes containing $1.4 \mathrm{~mm}$ ceramic spheres (MP Biomedicals). The tubes were vortexed 5 times for 2 min intervals, with 2 min breaks for cooling in the ice/water bath. Finally, the mixtures were centrifuged $\left(10,000 \times g, 4{ }^{\circ} \mathrm{C}\right.$, $20 \mathrm{~min}$ ), and the supernatant was pushed through the syringe filter, $0.22 \mu \mathrm{m}$ pore size, to remove unbroken cells. The thus-obtained cell-free extract was kept at $4{ }^{\circ} \mathrm{C}$ and used no later than $5 \mathrm{~h}$ after preparation.

\subsection{HPLC-MS Analysis of Conjugate Cleavage}

Analysis of cleavage of the conjugates was performed in two experimental systems: (A) model system, in the presence of pig liver esterase or glutathione, reduced; (B) in C. albicans cell-free extract.

System A

Mixtures containing a given conjugate at the initial concentration of $150 \mu \mathrm{M}$ and pig liver esterase, $5 \mathrm{mg} \mathrm{mL}^{-1}$ or $10 \mathrm{mM}$ glutathione, reduced, in a total volume of $200 \mu \mathrm{L}$ were incubated at $30^{\circ} \mathrm{C}$. Samples of $50 \mu \mathrm{L}$ were collected at zero time, after $30 \mathrm{~min}$, and after $120 \mathrm{~min}$ and subjected to HPLC-MS analysis.

System B

A given conjugate was dissolved in $4 \mathrm{~mL}$ of $C$. albicans cell-free extract to the initial concentration of $150 \mu \mathrm{M}$. Mixtures were incubated at $30^{\circ} \mathrm{C}$. Samples of $1 \mathrm{~mL}$ were collected at zero time, after $30 \mathrm{~min}$, and after $120 \mathrm{~min}$. The collected samples were immediately de-proteinized by centrifugation $\left(4^{\circ} \mathrm{C}, 5000 \times g, 10 \mathrm{~min}\right)$ in Amicon ${ }^{\circledR}$ Ultra- 4 Centrifugal Filter Units, $3 \mathrm{kDa}$ cutoff limit. Samples of $50 \mu \mathrm{L}$ were collected from the filtrates and subjected to HPLC-MS analysis. 
The HPLC-MS system consisted of a liquid chromatograph, a degasser, a binary pomp, an auto-sampler, and a column oven, which was combined with an MS detector with an electrospray source (AJS ESI) and quadrupole analyzer (1260 Infinity II and 6470 Triple Quad LC/MS, Agilent Technologies, Waldbronn, Germany). The ChemStation software was used to control the LC-MS system and for data processing.

Chromatographic separations were performed on an Eclipse XDB-C18 column $(150 \mathrm{~mm} \times 4.6 \mathrm{~mm}, 5 \mu \mathrm{m})$. For the separation, a gradient of mobile phase $\mathrm{A}\left(\mathrm{H}_{2} \mathrm{O}+0.01 \%\right.$ $\mathrm{HCOOH})$ and mobile phase $\mathrm{B}(100 \%$ methanol) was used. The gradient profile was set as follows: 0 min-95\% effluent A, 8 min-70\% effluent $A, 11$ min- $50 \%$ effluent $A$, $12 \mathrm{~min}-95 \%$ effluent $\mathrm{A}, 17 \mathrm{~min}-95 \%$ effluent $\mathrm{A}$. The flow rate was $1 \mathrm{~mL} \mathrm{~min}{ }^{-1}$, the column temperature was $25^{\circ} \mathrm{C}$, and the injection volume was $20 \mu \mathrm{L}$.

The electrospray source operated in a negative mode. The data were collected in a MS scanning mode (MS2 SCAN) with the range 150-700 ( $\mathrm{m} / \mathrm{z}$ ).

\subsection{Microscopic Examination of Conjugate Uptake}

Candida cells from the overnight culture in YPD medium were harvested, washed with distilled water, and used for inoculation of RPMI-1640 medium. The culture was grown at $30{ }^{\circ} \mathrm{C}$ with shaking from $\mathrm{OD}_{660} \approx 0.1$ to $\mathrm{OD}_{660} \approx 0.3$. The cells were harvested by centrifugation and immediately suspended in $\mathrm{PBS}$ to $\mathrm{OD}_{660} \approx 0.2$. A conjugate containing fluorescent probe was added to the final concentration of $50 \mu \mathrm{g} \mathrm{mL}^{-1}$, and the cell suspension was incubated $\left(30^{\circ} \mathrm{C}, 150 \mathrm{rpm}\right)$. Samples of $2 \mathrm{~mL}$ were collected at zero time and at time intervals, centrifuged, and washed 4 times with PBS. After the final wash, the cells were suspended in a small volume of PBS and immediately observed using the confocal microscopy ( $63 \times$ magnification; ZEISS LSM T-PMT, Magdeburg, Germany). The imaging conditions were as follows: conjugates containing Lys(Mca)—excitation $350 \mathrm{~nm}$, emission $385 \mathrm{~nm}$, and conjugates containing Nap- $\mathrm{NH}_{2}$ —excitation $438 \mathrm{~nm}$, emission $527 \mathrm{~nm}$.

Author Contributions: Conceptualization, S.M. and M.J.M.; Chemical synthesis and analysis, A.S.S.; Determination of biological properties, D.M.; Writing—original draft preparation, A.S.S. and S.M.; Writing—review and editing, M.J.M. and S.M.; Project administration and funding acquisition, S.M. All authors have read and agreed to the published version of the manuscript.

Funding: This research was funded in whole by the National Science Centre, Poland under the UMO-2020/39/B/ST4/01509 grant.

Institutional Review Board Statement: Not applicable.

Informed Consent Statement: Not applicable.

Data Availability Statement: For the purpose of Open Access, the author has applied a CC-BY public copyright license to any AAM version arising from this submission. Publicly available datasets were analyzed in this study. The data presented in this study are openly available from 4 August 2021 in [https://mostwiedzy.pl/pl/open-research-data] at [doi:10.34808/m04n-wx77].

Acknowledgments: The authors acknowledge the support of Katarzyna Kozłowska-Tylingo in RPHPLC-MS analyses. The FOSTER Foundation is gratefully acknowledged for the opportunity to perform experiments on a Zeiss LSM T-PMT Confocal Laser Scanning Microscope and 1260 Infinity II and 6470 Triple Quad LC/MS.

Conflicts of Interest: The authors declare no conflict of interest.

Sample Availability: Samples of the compounds 24a-d and 35 are available from the authors.

\section{References}

1. Spellberg, B. The future of antibiotics. Crit. Care 2014, 18, 228. [CrossRef] [PubMed]

2. Tacconelli, E.; Diletta Pezzani, M. Public health burden of antimicrobial resistance in Europe. Lancet Infect. Dis. 2019, 19, 4-6. [CrossRef]

3. Bongomin, F.; Gago, S.; Oladele, R.; Denning, D. Global and multi-national prevalence of fungal diseases destimate precision. J. Fungi 2017, 3, 57. [CrossRef] [PubMed] 
4. Fisher, M.C.; Hawkins, N.J.; Sanglard, D.; Gurr, S.J. Worldwide emergence of resistance to antifungal drugs challenges human health and food security. Science 2018, 360, 739-742. [CrossRef] [PubMed]

5. Patterson, T.F. Advances and challenges in management of invasive mycoses. Lancet 2005, 366, 1013-1025. [CrossRef]

6. Sanglard, D. Emerging threats in antifungal-resistant fungal pathogens. Front. Med. 2016, 3, 11. [CrossRef]

7. Huh, A.J.; Kwon, Y.J. "Nanoantibiotics”: A new paradigm for treating infectious diseases using nanomaterials in the antibiotics resistant era. J. Control. Release 2011, 156, 128-145. [CrossRef]

8. Pham, N.-T.; Loupias, P.; Dassonville-Klimpt, A.; Sonnet, P. Drug delivery systems designed to overcome antimicrobial resistance. Med. Res. Rev. 2019, 39, 2343-2396. [CrossRef]

9. Janout, V.; Regen, S.L. Bioconjugate-based molecular umbrellas. Bioconjug. Chem. 2009, 20, 183-192. [CrossRef]

10. Ge, G.; Wu, D.; Wang, Z.; Shi, W.; Wu, T.; Zhang, A.; Hong, S.; Wang, J.; Zhang, Y.; Ren, L. Cellular uptake mechanism of molecular umbrella. Bioconjug. Chem. 2009, 20, 2311-2316. [CrossRef]

11. Janout, V.; Di Giorgio, C.; Regen, S.L. Molecular umbrella-assisted transport of a hydrophilic peptide across a phospholipid membrane. J. Am. Chem. Soc. 2000, 122, 2671-2672. [CrossRef]

12. Janout, V.; Zhang, L.H.; Staina, I.V.; Di Giorgio, C.; Regen, S.L. Molecular umbrella-assisted transport of glutathione across a phospholipid membrane. J. Am. Chem. Soc. 2001, 123, 5401-5406. [CrossRef]

13. Janout, V.; Schell, W.A.; Thevenin, D.; Yu, Y.; Perfect, J.R.; Regen, S.L. Taming amphotericin B. Bioconjug. Chem. 2015, 26, 2021-2024. [CrossRef]

14. Regen, S.L. Improving the cellular selectivity of a membrane-disrupting antimicrobial agent by monomer control and by taming. Molecules 2021, 26, 374. [CrossRef] [PubMed]

15. Skwarecki, A.S.; Skarbek, K.; Martynow, D.; Serocki, M.; Bylińska, I.; Milewska, M.J.; Milewski, S. Molecular umbrellas modulate the selective toxicity of polyene macrolide antifungals. Bioconjug. Chem. 2018, 29, 1454-1465. [CrossRef] [PubMed]

16. Capobianco, J.O.; Zakula, D.; Coen, M.L.; Goldman, R.C. Anti-Candida activity of cispentacin: The active transport by amino acid permeases and possible mechanisms of action. Biochem. Biophys. Res. Commun. 1993, 190, 1037-1044. [CrossRef] [PubMed]

17. Oki, T.; Hirano, M.; Tomatsu, K.; Numata, K.; Kamei, H. Cispentacin, a new antifungal antibiotic. II. In vitro and in vivo antifungal activities. J. Antibiot. 1989, 42, 1756-1762.

18. Jethwaney, D.; Höfer, M.; Khaware, R.K.; Prasad, R. Functional reconstitution of a purified proline permease from Candida albicans: Interaction with the antifungal cispentacin. Microbiology 1997, 143, 397-404. [CrossRef] [PubMed]

19. Ziegelbauer, K. Decreased accumulation or increased isoleucyl-tRNA synthetase activity confers resistance to the cyclic betaamino acid BAY 10-8888 in Candida albicans and Candida tropicalis. Antimicrob. Agents Chemother. 1998, 42, 1581-1586. [CrossRef] [PubMed]

20. Parnham, M.J.; Bogaards, J.J.; Schrander, F.; Schut, M.W.; Oresković, K.; Mildner, B. The novel antifungal agent PLD-118 is neither metabolized by liver microsomes nor inhibits cytochrome P450 in vitro. Biopharm. Drug Dispos. 2005, 26, 27-33. [CrossRef]

21. Vijayaraghavan, S.; Jing, B.; Vrablik, T.; Chou, T.C.; Regen, S.L. Enhanced hydrolytic stability and water solubility of an aromatic nitrogen mustard by conjugation with molecular umbrellas. Bioconjug. Chem. 2003, 14, 667-671. [CrossRef] [PubMed]

22. Mintzer, M.A.; Dane, E.L.; O’Toole, E.A.; Grinstaff, M.W. Exploiting dendrimer multivalency to combat emerging and re-emerging infectious diseases. Mol. Pharm. 2012, 9, 342-354. [CrossRef]

23. Janout, V.; Bienvenu, C.; Schell, W.; Perfect, J.R.; Regen, S.L. Molecular umbrella-amphotericin B conjugates. Bioconjug. Chem. 2014, 25, 1408-1411. [CrossRef] [PubMed]

24. Franz, R.; Kelly, S.L.; Lamb, D.C.; Kelly, D.E.; Ruhnke, M.; Morschhäuser, J. Multiple molecular mechanisms contribute to a stepwise development of fluconazole resistance in clinical Candida albicans strains. Antimicrob. Agents Chemother. 1998, 42, 3065-3072. [CrossRef]

25. Clinical and Laboratory Standards Institute. Reference Method for Broth Dilution Antifungal Susceptibility Testing of Yeasts, 3rd ed.; Approved Standard M27-A3; Clinical and Laboratory Standards Institute: Wayne, PA, USA, 2008.

26. Ślisz, M.; Cybulska, B.; Mazerski, J.; Grzybowska, J.; Borowski, E. Studies of the effects of antifungal cationic derivatives of amphotericin B on human erythrocytes. J. Antibiot. 2004, 57, 669-678. [CrossRef] [PubMed] 